In cooperation with the U.S. Air Force

\title{
Degree of Contamination and Sources of Polychlorinated Biphenyls in Meandering Road Creek and Woods Inlet of Lake Worth, Fort Worth, Texas, 2004 and 2006-07
}

Scientific Investigations Report 2008-5177 
Blank Page 


\section{Degree of Contamination and Sources of Polychlorinated Biphenyls in Meandering Road Creek and Woods Inlet of Lake Worth, Fort Worth, Texas, 2004 and 2006-07}

By Christopher L. Braun, Jennifer T. Wilson, and Peter C. Van Metre

In cooperation with the U.S. Air Force

Scientific Investigations Report 2008-5177 


\section{U.S. Department of the Interior DIRK KEMPTHORNE, Secretary}

\section{U.S. Geological Survey \\ Mark D. Myers, Director}

\section{U.S. Geological Survey, Reston, Virginia: 2008}

For product and ordering information:

World Wide Web: http://www.usgs.gov/pubprod

Telephone: 1-888-ASK-USGS

For more information on the USGS — the Federal source for science about the Earth, its natural and living resources, natural hazards, and the environment:

World Wide Web: http://www.usgs.gov

Telephone: 1-888-ASK-USGS

Any use of trade, product, or firm names is for descriptive purposes only and does not imply endorsement by the U.S. Government.

Although this report is in the public domain, permission must be secured from the individual copyright owners to reproduce any copyrighted materials contained within this report.

Suggested citation:

Braun, C.L., Wilson, J.T., and Van Metre, P.C., 2008, Degree of contamination and sources of polychlorinated biphenyls in Meandering Road Creek and Woods Inlet of Lake Worth, Fort Worth, Texas, 2004 and 2006-07: U.S. Geological Survey Scientific Investigations Report 2008-5177, 64 p. 


\section{Contents}

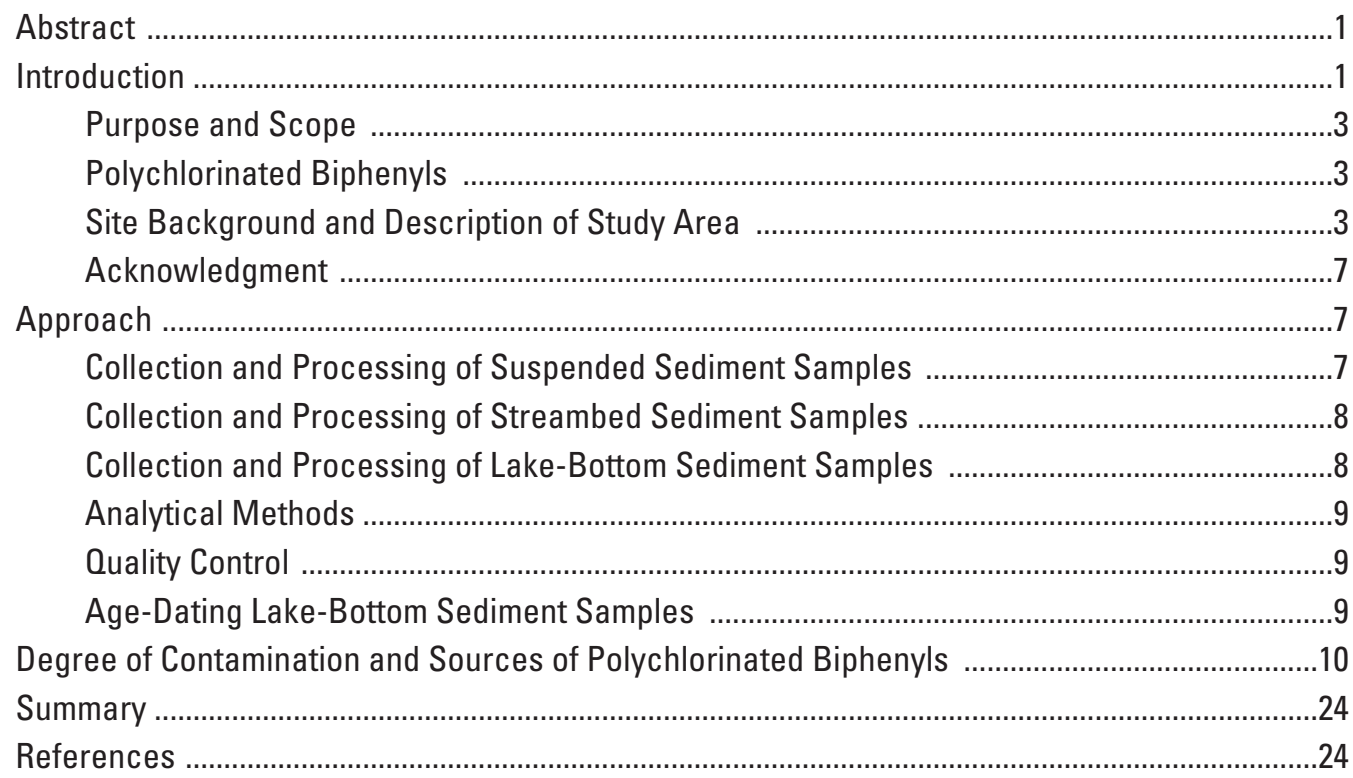

Appendixes

1. List of sampling sites, locations, dates, types of samples collected, and types of analyses in and near Meandering Road Creek and Woods Inlet of Lake Worth, Fort Worth, Texas, 2004 and 2006-07

2. Polychlorinated biphenyl (PCB) Aroclor and congener, organic carbon, and organochlorine pesticide concentrations in suspended, streambed, and lakebottom sediment samples from sites in and near Meandering Road Creek and Woods Inlet of Lake Worth, Fort Worth, Texas, 2004 and 2006-07

3. Quality control laboratory blank and spike sample results for polychlorinated biphenyl (PCB) Aroclor and organochlorine pesticide analyses for samples from sites in and near Meandering Road Creek and Woods Inlet of Lake Worth, Fort Worth, Texas, 2004 and 2006-07

4. Volatile organic compound concentrations in water samples from sites on or near Meandering Road Creek, Lake Worth, Fort Worth, Texas, 2004

5. Major and trace element concentrations in lake-bottom sediment samples from sites in Woods Inlet of Lake Worth, Fort Worth, Texas, 2006

\section{Figures}

1. Map showing location of Meandering Road Creek, Woods Inlet of Lake Worth, and Air Force Plant 4, Fort Worth, Texas

2. Map showing sampling sites on and near Meandering Road Creek and in Woods Inlet of Lake Worth, Fort Worth, Texas, 2004 and 2006-07

3. Graphs showing polychlorinated biphenyl (PCB) congener compositions of three widely used PCB Aroclors

4. Map showing suspended and streambed sediment sampling sites, 2004 and 2006-07, and areas of known polychlorinated biphenyl release near Woods Inlet of Lake Worth, Fort Worth, Texas 
5. Graphs showing ratios of total polychlorinated biphenyl (PCB) concentrations (as sum of three Aroclors [ $\left.\Sigma P C B_{A}\right]$ and as sum of 27 reported congeners $\left[\Sigma P C B_{C}\right]$ ) to threshold effect concentration (TEC), a consensus-based sediment quality guideline (MacDonald and others, 2000) for suspended, streambed, and lakebottom sediment samples collected from Meandering Road Creek and Woods Inlet of Lake Worth, Fort Worth, Texas, 2004 and 2006-07

6. Graphs showing total polychlorinated biphenyl (PCB) concentrations in suspended and streambed sediment samples from Besse and others (2005) and this report collected at sites on and near Meandering Road Creek and in Woods Inlet of Lake Worth, Fort Worth, Texas

7. Graphs showing polychlorinated biphenyl (PCB) congener concentrations and ratio of individual PCB congener concentrations to the sum of PCB congeners $\left(\Sigma P C B_{c}\right)$ at sites 4,5 , and 8 sampled for streambed sediment and site $S S 0$ sampled for suspended sediment on or near Meandering Road Creek, Lake Worth, Fort Worth, Texas, 2004 and 2006

8. Graphs showing polychlorinated biphenyl (PCB) congener concentrations and ratio of individual PCB congener concentrations to the sum of PCB congeners $\left(\Sigma \mathrm{PCB}_{\mathrm{C}}\right)$ at sites 1, 2, and 3 sampled for streambed sediment and sites OF4 and OF4 Flume sampled for suspended sediment on or near Meandering Road Creek, Lake Worth, Fort Worth, Texas, 2004 and 2006

9. Graphs showing polychlorinated biphenyl (PCB) congener concentrations and ratio of individual PCB congener concentrations to the sum of PCB congeners $\left(\Sigma P C B_{C}\right)$ at 15 sites sampled for lake-bottom sediment (WWD.1-WWD.3 and WWD.B1-WWD.B12), site OF5 sampled for suspended sediment, and site LMRC sampled for suspended and streambed sediment, Meandering Road Creek and Woods Inlet of Lake Worth, Fort Worth, Texas, 2004 and 2006-07

10. Graphs showing total polychlorinated biphenyl (PCB) concentrations (as sum of PCB Aroclors $\left[\Sigma P C B_{A}\right]$ and sum of $P C B$ congeners $\left[\Sigma P C B_{C}\right]$ ) and estimated deposition date for lake-bottom sediment samples from Woods Inlet of Lake Worth, Fort Worth, Texas, 2003 and 2006

11. Maps showing total polychlorinated biphenyl (PCB) concentrations as the sum of PCB congeners $\left(\Sigma P C B_{C}\right)$ in lake-bottom sediment samples from Woods Inlet of Lake Worth, Fort Worth, Texas, 2003 and 2006

\section{Tables}

1. Relative percent differences of duplicate samples from Meandering Road Creek and Woods Inlet of Lake Worth, Fort Worth, Texas, for this report and a previous U.S. Geological Survey report

2. Porosities, mass accumulation rates, and estimated deposition dates for 2006 lake-bottom sediment samples and 2003 gravity core samples from Woods Inlet of Lake Worth, Fort Worth, Texas

\section{Datum}

Horizontal coordinate information is referenced to the North American Datum of 1983 (NAD 83). 


\title{
Degree of Contamination and Sources of Polychlorinated Biphenyls in Meandering Road Creek and Woods Inlet of Lake Worth, Fort Worth, Texas, 2004 and 2006-07
}

\author{
By Christopher L. Braun, Jennifer T. Wilson, and Peter C. Van Metre
}

\section{Abstract}

Lake Worth is a reservoir on the West Fork Trinity River on the western edge of Fort Worth, Texas. Air Force Plant 4 (AFP4) is on the eastern shore of Woods Inlet, an arm of Lake Worth that extends south from the main body of the lake. Two previous reports documented elevated polychlorinated biphenyl (PCB) concentrations in surficial sediment in Woods Inlet relative to those in surficial sediment in other parts of Lake Worth. This report presents the results of another USGS study, done in cooperation with the U.S. Air Force, to indicate the degree of PCB contamination of Meandering Road Creek and Woods Inlet and to identify possible sources of PCBs in Meandering Road Creek and Woods Inlet on the basis of suspended, streambed, and lake-bottom sediment samples collected there in 2004 and 2006-07. About 40 to 80 percent of total PCB concentrations (depending on how total PCB concentration is computed) in suspended sediment exceed the threshold effect concentration, a concentration below which adverse effects to benthic biota rarely occur. About 20 percent of total PCB concentrations (computed as sum of three Aroclors) in suspended sediment exceed the probable effect concentration, a concentration above which adverse effects to benthic biota are expected to occur frequently. About 20 to 30 percent of total PCB concentrations in streambed sediment exceed the threshold effect concentration; and about 6 to 20 percent of total PCB concentrations in lake-bottom (Woods Inlet) sediment exceed the threshold effect concentration. No streambed or lake-bottom sediment concentrations exceed the probable effect concentration. The sources of PCBs to Meandering Road Creek and Woods Inlet were investigated by comparing the relative distributions of PCB congeners of suspended sediment to those of streambed and lake-bottom sediment. The sources of PCBs were identified using graphical analysis of normalized concentrations (congener ratios) of 11 congeners. For graphical analysis, the sampling sites were divided into three groups with each group associated with one of the three outfalls sampled: SSO, OF4, and OF5. The variations of normalized PCB congener concentrations from Woods Inlet, from outfalls along Meandering Road Creek, and from streambed sediment sampling sites along Meandering Road Creek generally form similar patterns within sample groups, which is indicative of a common source of PCBs to each group. Overall, the variations in congener ratios indicate that PCBs in surficial lake-bottom sediment of Woods Inlet probably entered Woods Inlet primarily from Meandering Road Creek, and that runoff from AFP4 is a prominent source of PCBs in Meandering Road Creek. Sixteen of the 20 box core sites in Woods Inlet had lower PCB concentrations in the 2006 cores compared to those in the 2003 cores.

\section{Introduction}

Lake Worth is a reservoir on the West Fork Trinity River on the western edge of Fort Worth, Tex. Air Force Plant 4 (AFP4) is on the eastern shore of Woods Inlet, an arm of Lake Worth that extends south from the main body of the lake, east of Interstate Highway 820 (fig. 1). In August 1990, AFP4 was placed on the U.S. Environmental Protection Agency (USEPA) National Priorities List of the most serious known hazardous waste sites in the Nation due to ground-water contamination (U.S. Environmental Protection Agency, 1990). A Preliminary Assessment/Site Inspection (PA/SI) and a Remedial Investigation/Feasibility Study (RI/FS) of the site began in October 1990 to characterize the extent of contamination. In September 1995, the USEPA and the (then) Texas Natural Resource Conservation Commission approved the RI/FS, and in July 1996, a final Record of Decision that detailed possible remedial actions was issued (RUST Geotech, 1996).

The Texas Department of Health (TDH) and the Agency for Toxic Substances and Disease Registry evaluated the PA/SI in July 1998 and concluded that an indeterminate public health hazard existed in Lake Worth from exposure to contaminants through the food chain (Texas Department of Health, 1998); this conclusion was reached after elevated concentrations of contaminants, such as polychlorinated biphenyls (PCBs), were detected in small, inedible fish species known as mosquito fish. In spring 2000, the TDH issued a fish-consumption advisory following fish sampling by the U.S. Geological Survey 


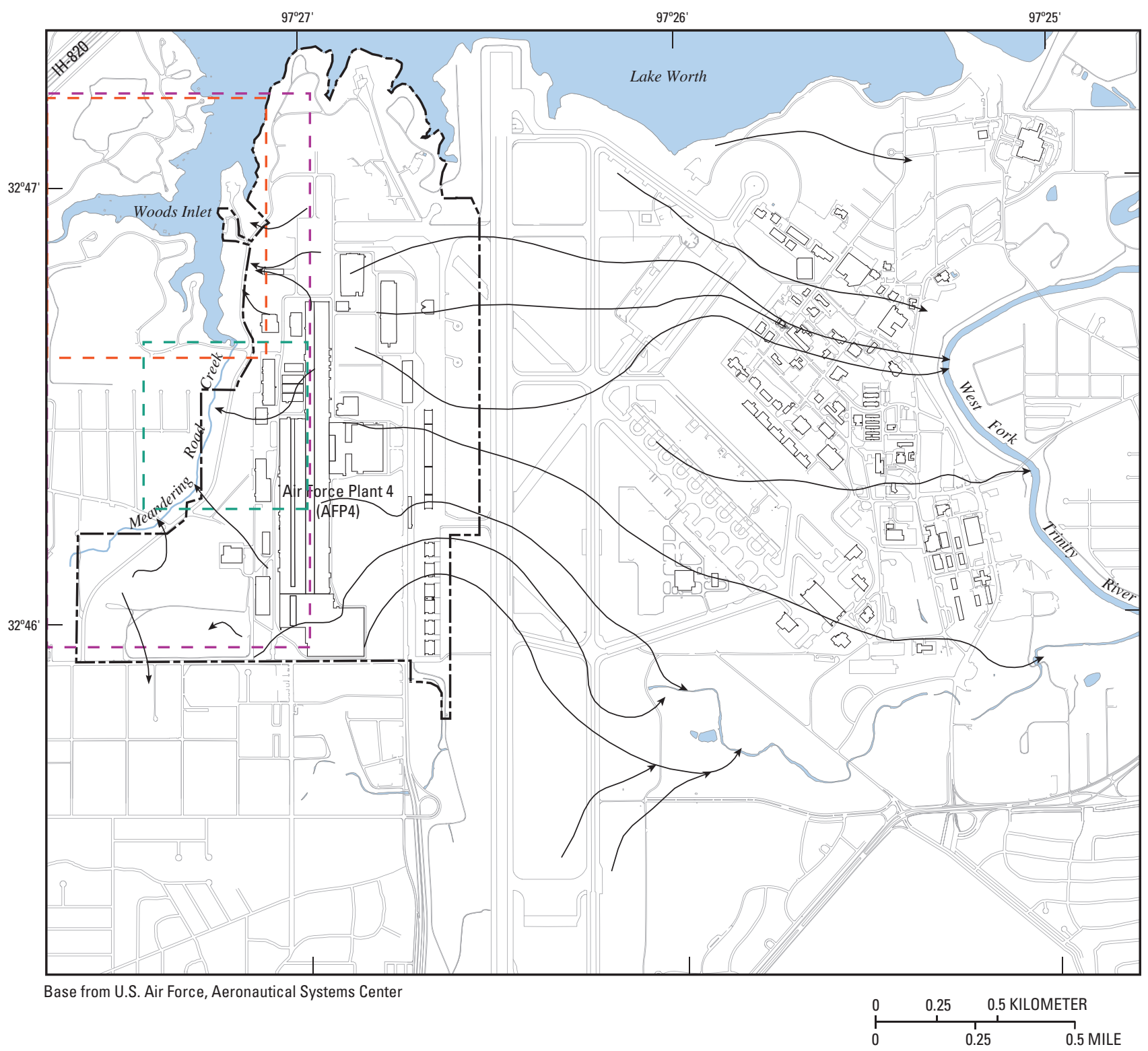

\section{EXPLANATION}
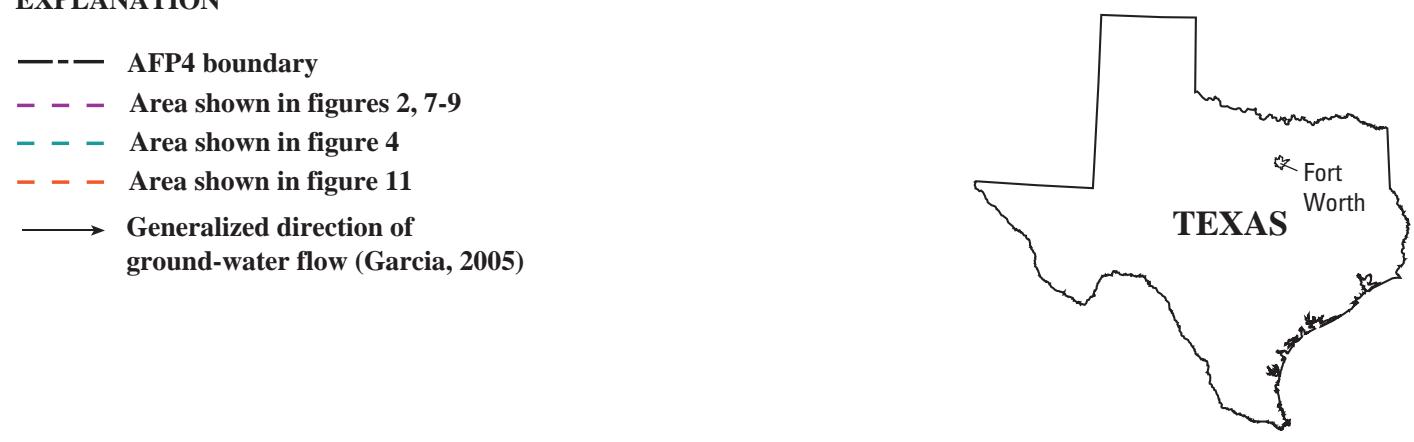

LOCATION MAP

Figure 1. Location of Meandering Road Creek, Woods Inlet of Lake Worth, and Air Force Plant 4, Fort Worth, Texas. 
(USGS) (Moring, 2002) because high levels of PCBs detected in fish samples posed a "significant health risk" (Texas Department of Health, 2004).

The occurrence of PCBs in fish led to an investigation by the USGS, in cooperation with the U.S. Air Force (USAF), to sample Lake Worth lake-bottom sediment and analyze for sediment-associated contaminants, including PCBs. The USGS report of that study (Harwell and others, 2003) documented elevated PCB concentrations in surficial sediment in Woods Inlet relative to those in surficial sediment in other parts of Lake Worth. This finding indicated that the Woods Inlet watershed likely contained a source of PCBs.

In 2003, the USGS conducted a second study, again in cooperation with the USAF, in response to the elevated PCB concentrations in sediment in Woods Inlet. This study was designed to map the distribution of elevated PCB concentrations in Woods Inlet and to identify possible source areas of PCBs in the watershed of Woods Inlet. The findings of that report (Besse and others, 2005) indicated the highest PCB concentrations near the mouth of Meandering Road Creek (fig. 2); concentrations decreased consistently from the mouth of the creek toward the main body of Lake Worth. This finding indicated that PCBs are originating in the Meandering Road Creek watershed. Total PCB concentrations in suspended and streambed sediment indicated storm drain outfall site OF4, which receives runoff from AFP4, as a likely source of PCBs to Meandering Road Creek and ultimately Woods Inlet. However, the study did not determine whether site OF4 was the only source of PCBs to Meandering Road Creek and Woods Inlet. Results from the two previous USGS studies (Harwell and others, 2003; Besse and others, 2005) prompted the study reported here, conducted in cooperation with the USAF.

\section{Purpose and Scope}

The purposes of this report are (1) to indicate the degree of PCB contamination of Meandering Road Creek and Woods Inlet by comparing concentrations of PCBs in suspended, streambed, and lake-bottom sediment samples to consensusbased sediment quality guidelines (SQGs) of MacDonald and others (2000), and (2) to identify possible sources of PCBs in Meandering Road Creek and Woods Inlet on the basis of concentrations of PCBs in suspended, streambed, and lake-bottom sediment samples. Concentrations of PCBs were obtained from analyses of stormwater suspended sediment samples collected from outfalls to Meandering Road Creek during storms in 2004, 2006, and 2007; streambed sediment samples collected in Meandering Road Creek in 2004 and 2006; and lake-bottom sediment samples collected in Woods Inlet in 2006. PCB concentrations in samples of the three media also are compared to concentrations in samples from the same sites in two previous USGS studies (Harwell and others, 2003; Besse and others, 2005). Sources of PCBs are identified by comparing the relative distributions of $\mathrm{PCB}$ congeners (chlorinated compounds, the mixtures of which form PCB Aroclors) of suspended sediment to those of streambed and lake-bottom sediment samples using graphical analysis. Samples collected at some sites also were analyzed for organochlorine pesticides, volatile organic compounds, and major and trace elements. The analytical results for these constituents are included in the appendixes but are not discussed in this report.

\section{Polychlorinated Biphenyls}

PCBs were first synthesized in the early 1930s and have had widespread industrial uses, primarily as plasticizers, hydraulic lubricants, and dielectric fluids in electric capacitors (Smith and others, 1988). Adverse human health effects and cancer in animals have been associated with exposure to PCBs. The manufacture of PCBs was stopped in 1977 (Agency for Toxic Substances and Disease Registry, 2001).

PCBs are hydrophobic contaminants that sorb strongly to organic matter and particulates. They commonly are detected in urban lakes and reservoir sediments (Van Metre and others, 1997; Van Metre and others, 1998; Long and others, 2003).

PCB concentrations in sediment cores from urban lakes typically peak in sediment deposited during the late 1960s, coinciding with the years of greatest PCB use, and then decrease in more recently deposited sediment because of restrictions imposed during the 1970s (Van Metre and others, 1997; Van Metre and others, 1998).

PCBs are mixtures of a subset of as many as 209 theoretically possible chlorinated compounds, called congeners, with various numbers and positions of chlorine atoms attached to the biphenyl structure. Each congener has been assigned a congener number; congener number increases generally with increasing chlorination of the biphenyl structure (fig. 3). Mixtures of PCB congeners were commonly marketed and sold by the trade name Aroclor. The analytical methods applied in this study quantify 27 common PCB congeners and three common Aroclor mixtures (1016/1242, 1254, and 1260). Figure 3 shows the congener compositions of Aroclor mixtures 1242, 1254, and 1260 and highlights (in yellow) the contributions of the 27 congeners analyzed by the USGS National Water Quality Laboratory (NWQL) in these Aroclor mixtures.

\section{Site Background and Description of Study Area}

AFP4 was built in 1942 to manufacture aircraft and encompasses 2.44 square kilometers $\left(\mathrm{km}^{2}\right)$ of land east of Woods Inlet. Waste materials (fuels, oils, solvents, paint residues, and spent process chemicals) generated at the plant were placed in on-site landfills or burned in fire-training exercises prior to 1973 (Texas Department of Health, 1998). During the RI/FS, certain areas were identified as having contaminant concentrations in soil and sediment that could pose a risk to human health or the environment or that exceed the lower threshold of a defined acceptable risk range. These areas include soils associated with historical landfills 1 and 3 


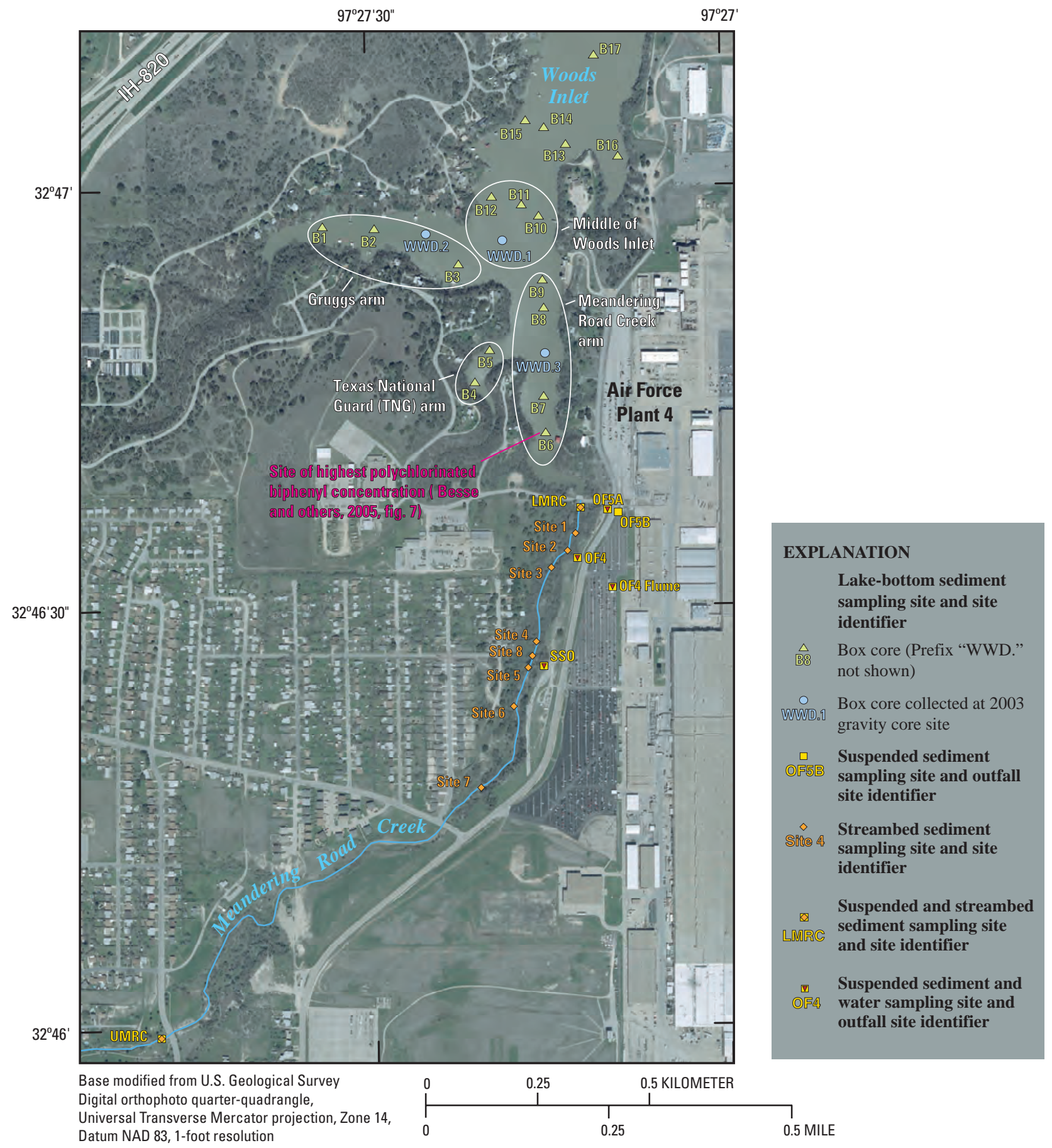

Figure 2. Sampling sites on and near Meandering Road Creek and in Woods Inlet of Lake Worth, Fort Worth, Texas, 2004 and 2006-07.

and sediment along Meandering Road Creek and Woods Inlet (fig. 4).

Landfill 1, on the east side of Bomber Road, encompasses about 2.4 hectares $\left(0.024 \mathrm{~km}^{2}\right)$. It was used as a disposal site for construction fill, general waste, and potentially hazardous wastes including solvents, thinners, paint, and unspecified liquid waste (International Technology Corporation, 2001).
Fuel and oil also were dumped into several shallow pits within landfill 1 and burned. In 1966, landfill 1 was closed, and the area was graded and paved to make the west parking lot (fig. 4). A part of landfill 1 was excavated in 1983, and the excavated material was sent to an off-site disposal facility. Before backfilling the excavated area, a French drain was installed to intercept contaminated ground water. A second 


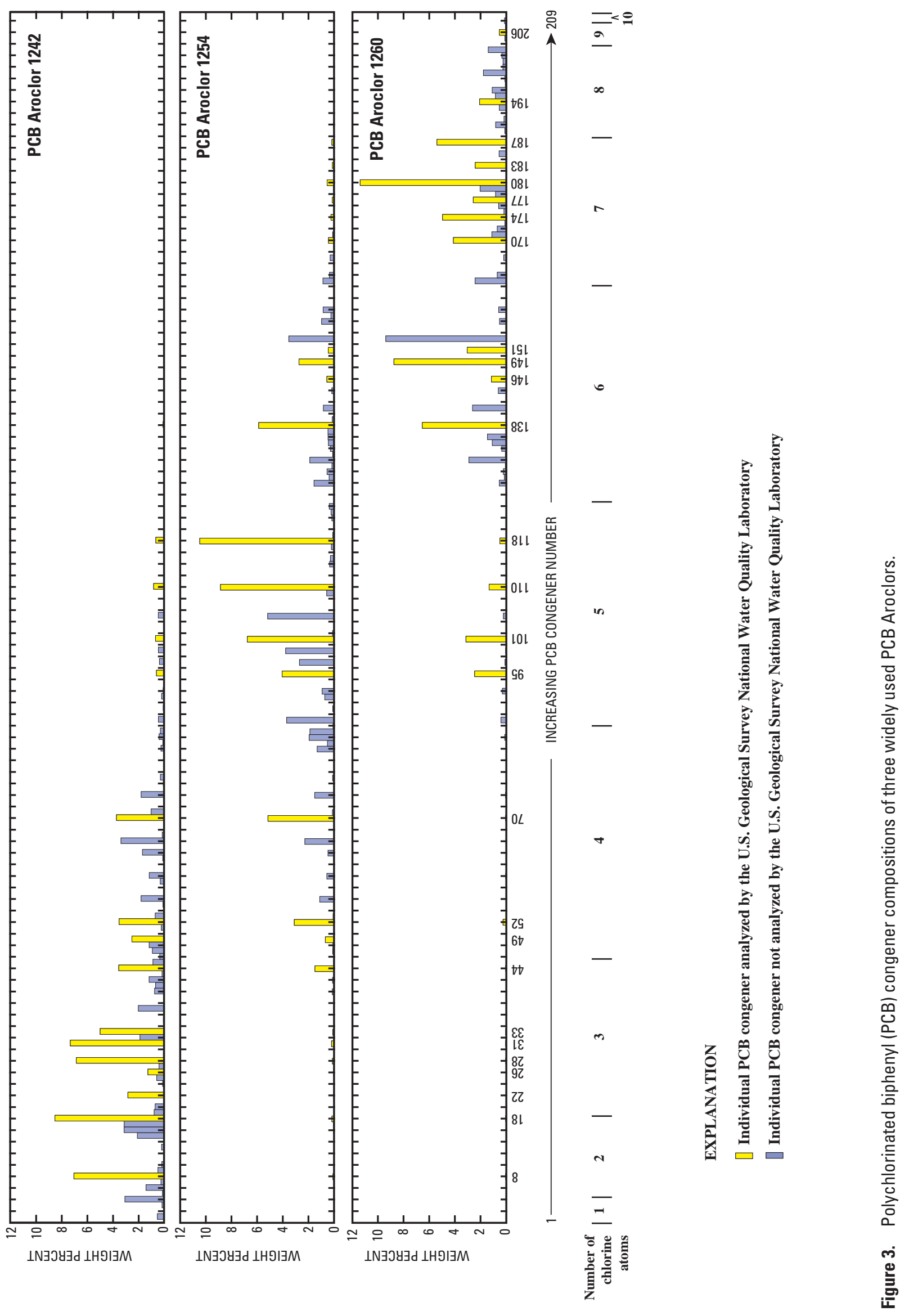


$97^{\circ} 27^{\prime} 22.5^{\prime \prime}$

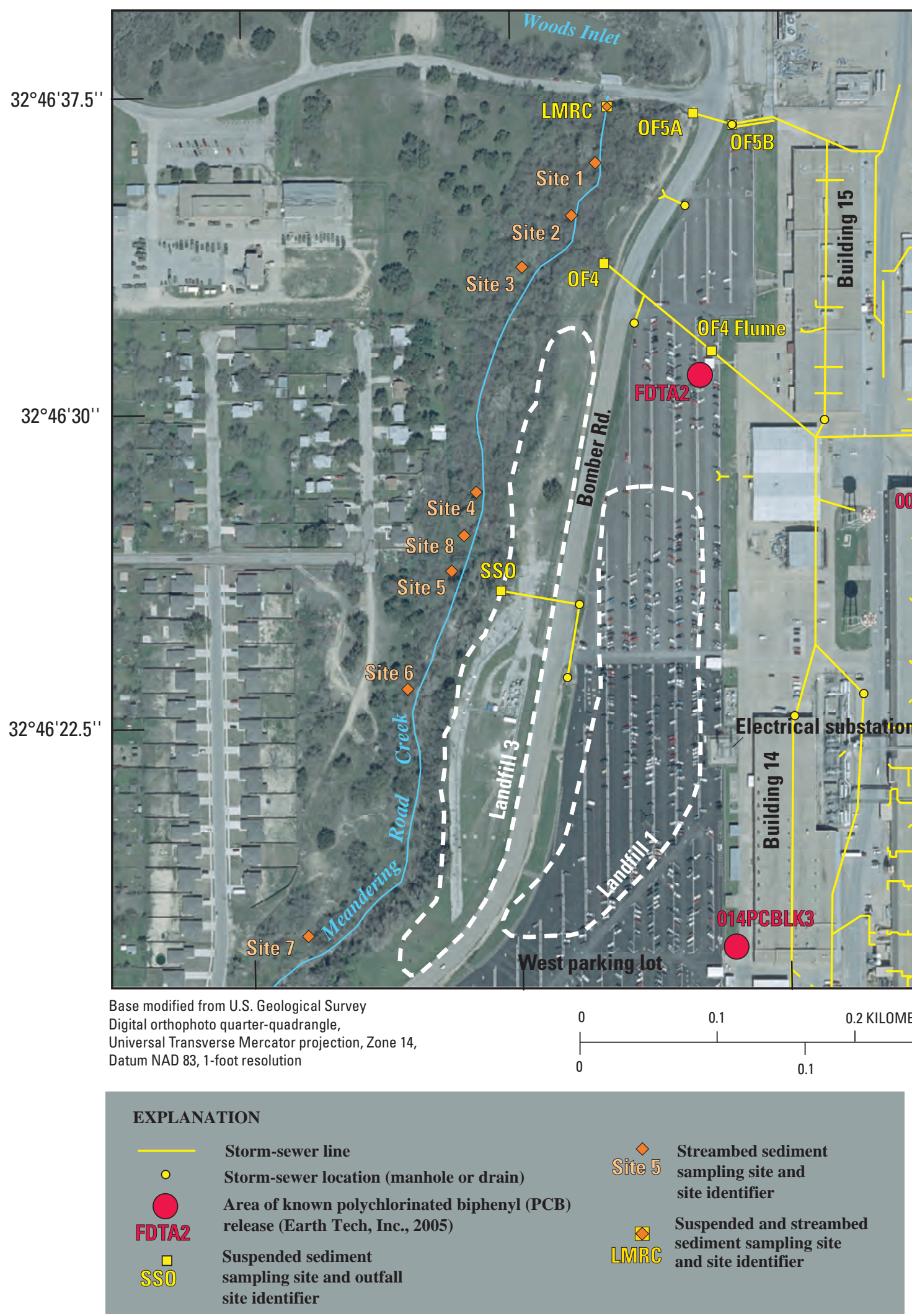

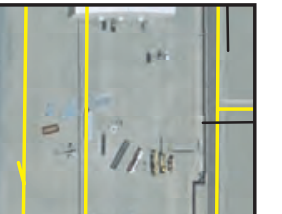


French drain was installed in an embankment along the eastern shoulder of Bomber Road to intercept oily water that would have otherwise seeped into a storm sewer that drains to Meandering Road Creek.

Landfill 3, on the west side of Bomber Road, was used as a disposal site from 1942 to 1945 for various wastes, including hazardous oils and solvents (International Technology Corporation, 2001). Soil and rubble were used to fill and grade the site during 1966-67. In 1994, a vacuum-enhanced pumping system was installed by the USAF along the western edge of landfill 3 to prevent seepage of ground water and landfill leachate into Meandering Road Creek.

Meandering Road Creek borders AFP4 to the west and flows north to the Woods Inlet of Lake Worth. Woods Inlet is the historical stream channel of Meandering Road Creek, which was flooded when the reservoir was impounded. Meandering Road Creek is an intermittent stream that receives runoff from numerous stormwater outfalls (sites SSO, OF4, OF4 Flume, and OF5 [OF5A and B considered one site]) (fig. 4) that drain areas of AFP4, including the two historical landfills (landfills 1 and 3). Ground-water discharge (seeps) along the eastern edge of Meandering Road Creek and stormwater runoff from urban areas to the south and west of AFP4 also contribute to streamflow. The watershed area for Meandering Road Creek $\left(4.1 \mathrm{~km}^{2}\right)$ is 46 percent urban (including industrial and transportation categories) (Besse and others, 2005, p. 5).

Outfall 5 (OF5) contributes to Meandering Road Creek about 25 meters (m) upstream from the point where Meandering Road Creek enters Woods Inlet (fig. 4); OF5 receives runoff from parking areas and Building 15. Outfall 4 (OF4) contributes to Meandering Road Creek about 200 m upstream from the point where Meandering Road Creek enters Woods Inlet and receives runoff from buildings, parking areas, and landfill 1. The OF4 Flume discharges directly into OF4 but does not receive runoff from the west parking lot. The stormsewer outfall (SSO) contributes to Meandering Road Creek about $400 \mathrm{~m}$ upstream from the point where Meandering Road Creek joins Woods Inlet; SSO receives runoff from parking areas and landfill 1.

Two notable PCB leaks or spills have been documented on the west side of AFP4 (Earth Tech, Inc., 2005). The first spill occurred in March 1984 when the failure of a transformer in an electrical substation adjacent to Building 14 (fig. 4; 014PCBLK3) resulted in the release of an unknown quantity of oil containing approximately 10.9 parts per million (ppm) of PCBs. Surface-water runoff from this area collects in storm drains that eventually discharge to Meandering Road Creek at either OF4 or SSO. This spill occurred next to a storm-sewer line that ultimately discharges to Meandering Road Creek at OF4.

In March 1989, PCBs were detected beneath a concrete slab in Building 5 (fig. 4: 005PCBLK1). Concentrations of solvents similar to those observed at landfills 1 and 3 also have been detected near the former Fire Department Training Area 2 (FDTA2). This training area, north of landfill 1, was described as a 50-foot-diameter earthen ring (RUST Geotech,
1995) that was used for semiannual fire training exercises between 1955 and 1965. FDTA2 also might have been used for disposal of waste oils and fuels (CH2M Hill, 1984). FDTA2 is next to a storm-sewer line that ultimately discharges to Meandering Road Creek at OF4.

\section{Acknowledgment}

The authors thank Lockheed Martin Corporation for access to the sampling sites.

\section{Approach}

PCBs in storm runoff were investigated by sampling suspended sediment at four outfalls contributing to Meandering Road Creek (fig. 4) during as many as three storms in 2004 and by sampling streambed sediment at eight sites along Meandering Road Creek within 24 hours of the storm on November 16, 2004. This investigation continued in 2006-07 when suspended sediment samples were collected during two storms at three of the four outfalls previously sampled. Suspended sediment samples also were collected from two sites in Meandering Road Creek, LMRC and UMRC. Site LMRC is near the mouth of Meandering Road Creek (figs. 2, 4) and receives runoff from outfalls $\mathrm{OF} 4, \mathrm{OF} 5$, and $\mathrm{SSO}$, landfills 1 and 3, and urban areas south and west of AFP4. Site UMRC is upstream from AFP4 (fig. 2) and receives runoff from urban areas but not from AFP4 and for this reason is considered a reference site. Streambed sediment samples were collected August 29, 2006, from the same eight sites that were sampled once in 2004 (sites 1-8; fig. 4) plus sites LMRC and UMRC. All streambed sediment samples were analyzed using laboratory methods identical to those described in the previous USGS studies at Lake Worth (Harwell and others, 2003; Besse and others, 2005).

The contribution of PCBs from Meandering Road Creek to Woods Inlet was investigated by sampling lake-bottom sediment at 20 sites in 2006 (fig. 2). The 2006 lake-bottom sediment sampling sites were the same sites sampled in 2003 (Besse and others, 2005). Surficial sediment samples were collected at each site to determine the change in PCB concentrations between 2003 and 2006. All lake-bottom sediment samples were analyzed using laboratory methods identical to those described in the previous USGS studies at Lake Worth (Harwell and others, 2003; Besse and others, 2005) to allow comparisons between the analytical results. Appendix 1 lists all sampling sites, dates, types of samples collected, and types of analyses done for this report.

\section{Collection and Processing of Suspended Sediment Samples}

Suspended sediment samples were collected in 2004 at four sites (SSO, OF4 Flume, OF4, and OF5) during as many 
as three storms. Suspended sediment samples were collected in 2006 at five sites (UMRC, LMRC, OF4 Flume, OF4, and OF5) during two storms, except OF5, which was sampled only during one storm because the runoff during the second storm did not contain sufficient sediment to merit sampling, and OF4 Flume, which generated insufficient storm runoff to collect a second sample in 2006. Samples were not collected at SSO in 2006 because there was insufficient flow in the drainpipe to sample. A suspended sediment sample also was collected at OF5 in 2007 to help verify results from a sample collected previously (October 10, 2006) for which analytical detection levels were unusually high because of small sample mass. The sample collected at OF5 on October 10, 2006, was collected at the location labeled OF5B in figure 4; all other samples collected at OF5 were collected at the location labeled OF5A. This small difference in sampling location should not affect the results because there is no potential for additional runoff contributions between the two locations.

Suspended sediment samples were collected by filling 25-liter (L) Nalgene carboys with runoff from the "first flush" (initial rise in flow) at each of the sites during a storm. Additional carboys were filled during some storms at some sites where suspended sediment concentration was too small (based on visual inspection and judgment) to provide a sufficient mass of suspended sediment for chemical analyses. The 25-L carboys were transported to the USGS office in Fort Worth and stored on ice until filtering. Filtering each sample took several hours, so processing all samples from a storm typically took from 1 to 2 days after the storm. In all, eight environmental samples for suspended sediment were collected in 2004, nine environmental samples and one environmental duplicate sample were collected in 2006, and one environmental sample and one environmental duplicate sample were collected in 2007 (appendix 2). One of the environmental samples, the sample collected at OF5 on August 27, 2006, was destroyed before analysis at the laboratory when the sample jar broke.

Sediment was isolated from the water samples by in-line filtration following the methods of Mahler and Van Metre (2003). The 25-L carboy was agitated to suspend the sediment in the stormwater sample and immediately poured into a $25-\mathrm{L}$ churn. The churn has a paddle that, with steady motion, keeps the sediment suspended and the sample well mixed during filtration. As the first 25-L carboy was filtered, additional sample was added to the churn from additional carboys, when collected. Sediment for the analysis of organic compounds was collected on a 293-millimeter $(\mathrm{mm})$ diameter, 0.45-micrometer $(\mu \mathrm{m})$ pore size polytetrafluoroethylene filter in a stainless steel filter holder. Water was pumped from the churn with a peristaltic pump through the filter until the filter clogged. The volume of water that passed though the filter was noted. The filter was removed from the holder and placed in a locking plastic bag with 10 to 20 milliliters (mL) of deionized water. The filter was gently massaged in the bag to release the sediment from the filter. This process was repeated, usually three to six times, until approximately 2 to 5 grams dry sediment mass was isolated for analysis. The sediment slurry was then poured into a $125-\mathrm{mL}$ glass IChem jar for organic and inorganic analyses. The samples for organic analysis were allowed to settle for approximately 4 days under refrigeration at which point the overlying water was decanted with a sterile glass pipette, and the samples were sent chilled to the NWQL.

\section{Collection and Processing of Streambed Sediment Samples}

Streambed sediment samples were collected on November 16, 2004, and again on August 29, 2006. Eight environmental samples and one duplicate sample were collected on November 16, 2004. Ten environmental samples and two duplicate samples were collected on August 29, 2006 (appendix 2). Streambed sediment samples were collected using a pre-cleaned nylon spoon to scoop subsamples of fine-grained sediment from the streambed in depositional areas (Shelton and Capel, 1994). The subsamples from each site were put into wide-mouth glass jars and taken to the USGS laboratory in Fort Worth for processing in 2004 and to the USGS laboratory in Austin, Tex., in 2006. At each site, $2 \mathrm{~L}$ of native water was collected for sieving the samples. In the laboratory, the sediment from each site was poured into a large pre-cleaned Pyrex mixing bowl and homogenized with a Teflon spatula. The material was sieved using a 2-mm mesh stainless steel sieve, and the fraction less than $2 \mathrm{~mm}$ was collected in a $250-\mathrm{mL}$ baked-glass jar for analysis of organic compounds. Samples for analysis of organic compounds were shipped chilled to the NWQL.

\section{Collection and Processing of Lake-Bottom Sediment Samples}

Seventeen of the 20 lake-bottom sediment sampling sites in Woods Inlet were sampled for surficial sediment only (top 1 or 2 centimeters [cm]; labeled B1-17 in fig. 2), which was collected with a 14 - by 14 - by 20 -cm Wildco box corer. The box cores were subsampled on-site by vertical extrusion and sectioning following the methods of Van Metre and others (2004). Samples for analysis of organic compounds were transferred to a baked-glass jar and chilled pending shipment to the NWQL.

Box cores also were collected at three sites sampled by gravity core in 2003 (Besse and others, 2005) to continue an investigation of historical trends of sediment-associated contaminants (fig. 2). The 2003 gravity cores were collected in the main body of Woods Inlet (site WWD.1) and in the two largest tributary arms, Gruggs arm (site WWD.2) and Meandering Road Creek arm (site WWD.3). Gravity corers are used to collect deep sediment deposits, typically penetrating the entire lacustrian sediment thickness down to the pre-reservoir land surface; thus a sample of sediment deposited at the collection site from the date of reservoir construction to the gravity core collection date is obtained. 
When the three gravity coring sites were revisited in 2006 , cores were collected using a 14 - by 14 - by $20-\mathrm{cm}$ Wildco box corer. The box cores were subsampled on-site by vertical extrusion of the sediment in measured intervals using a piston fit into the bottom of the liner. The box cores were subsampled from 0 to 1,1 to 3,3 to 5,5 to 10 , and 10 to $15 \mathrm{~cm}$ (10- to 13-cm bottom interval at site WWD.3). Sampling tools were washed between each sample interval using phosphatefree detergent and native water. Samples for analyses of organic compounds were transferred to baked-glass jars and chilled pending shipment to the NWQL.

\section{Analytical Methods}

PCBs were extracted, isolated, and analyzed using the procedures of Noriega and others (2003). Briefly, wet lake-bottom sediment was extracted overnight with dichloromethane in a Soxhlet apparatus. The extract was reduced in volume and filtered. An aliquot of the sample extract was quantitatively injected into a polystyrene-divinylbenzene gel permeation column (GPC) and eluted with dichloromethane to remove sulfur and partially isolate the target analytes from coextracted high-molecular-weight interferents such as humic substances. The aliquot was further split into two fractions by combined alumina/silica adsorption chromatography followed by a micro Florisil column cleanup step prior to determination of the PCBs by dual capillary-column gas chromatography with electron capture detection (GC-ECD) (Olson and others, 2004). PCBs were reported as individual Aroclor (1016/1242, 1254, or 1260) equivalents (Noriega and others, 2003).

For this report, fraction 1 (PCB fraction) of the organiccompound analysis was analyzed for 27 selected (of 209 possible) PCB congeners (fig. 3) along with the other fraction 1 analytes (PCB Aroclors) during GC-ECD analysis. The congeners chosen for this analysis were some of the more dominant congeners in widely used Aroclors (1016/1242, 1254 , and 1260). In addition to the dominance of these congeners, potential co-elution issues and signal response for this analytical method were considered. A series of dilutions of a custom mixture containing the 27 selected PCB congeners was used to make the calibration standards. Calibration standards were prepared at four concentrations, and a minimum of three points were used for the calibration curves. An additional congener solution, prepared at a concentration that was midrange on the curve, was used as a check standard to verify the calibration curve.

The laboratory reporting level for PCB Aroclors was 5.0 micrograms per kilogram ( $\mu \mathrm{g} / \mathrm{kg})$; however, variations in sample mass, sample matrix, and analytical interferences raised reporting levels as high as $720 \mu \mathrm{g} / \mathrm{kg}$. A laboratory reporting level has not been established for individual congeners (W.T. Foreman, U.S. Geological Survey, written commun., 2001); however, it is believed to be conservatively about $1.0 \mu \mathrm{g} / \mathrm{kg}$ (M.C. Noriega, U.S. Geological Survey, oral commun., 2003). Congener concentrations less than the reporting level were quantified when the analyst was confident in the detection; those values were identified in the data tables in appendix 2 as estimated (E). A comparison of all suspended, streambed, and lake-bottom sediment samples indicated that the sum of the 27 congeners accounted for 57 percent (average, \pm 6 percent [ 1 standard deviation]) of the sum of the Aroclors.

\section{Quality Control}

Quality control for PCB analyses consisted of analyzing a laboratory blank sample, a spiked sample, and a duplicate, and monitoring recovery of surrogate compounds with each set of 12 environmental samples (Noriega and others, 2003; Olson and others, 2004). There were no detections of PCBs in the blank samples. Median spike recoveries were 96 percent for PCBs and spike recoveries were within control limits for 76 percent of the spike results.

Analytical results from two types of duplicate samples are included in this report-environmental duplicates and laboratory duplicates (appendix 3). An environmental duplicate is a sample that is split into two jars at the time of collection; both jars are submitted to the laboratory for analysis. A laboratory duplicate is a single sample that is split by the laboratory during preparation and analyzed in duplicate. Although the analytical methods of organic compound analysis were the same for all sediment samples, sample mass was small enough for suspended sediment samples that reporting levels and precision were affected, and therefore relatively few suspended sediment duplicate samples were analyzed. Nine environmental duplicate samples were analyzed for PCBstwo suspended sediment, three streambed sediment, and four lake-bottom sediment samples. A summary of the relative percent differences (RPDs) of the duplicate sample analyses for this report and a previous USGS report for Woods Inlet of Lake Worth (Besse and others, 2005) is in table 1. The median RPDs for this report are greater than those of the previous report for core sediment samples, appreciably less for surficial bottom sediment samples, about the same for streambed sediment samples, and appreciably less for suspended sediment samples. Only the original, and not the duplicate, sample results are used in the calculations and figures in this report.

\section{Age-Dating Lake-Bottom Sediment Samples}

The deposition dates of the lake-bottom sediment samples collected at sites WWD.1, WWD.2, and WWD.3 were estimated using sediment mass accumulation rates (MARs) calculated for the lake-bottom sediment gravity cores collected at the same sites in 2003 (Besse and others, 2005, appendix 1.1). Briefly, the 2003 gravity cores were age-dated using the pre-reservoir boundary, ${ }^{137} \mathrm{Cesium}\left({ }^{137} \mathrm{Cs}\right)$ concentrations, sediment porosity and mass, and an exponential model to account for decreasing sedimentation rate over time as the reservoir shoreline stabilizes (Callender and Robbins, 1993; Van Metre and others, 2004). The lake-bottom sediment 
Table 1. Relative percent differences of duplicate samples from Meandering Road Creek and Woods Inlet of Lake Worth, Fort Worth, Texas, for this report and a previous U.S. Geological Survey report (Besse and others, 2005).

[(n), number of samples; RPDs, relative percent differences; PCB, polychlorinated biphenyl]

\begin{tabular}{|c|c|c|c|c|c|c|c|c|c|c|c|c|}
\hline \multirow{3}{*}{ Constituent } & \multicolumn{3}{|c|}{$\begin{array}{c}\text { Suspended sediment } \\
\text { samples }\end{array}$} & \multicolumn{3}{|c|}{$\begin{array}{c}\text { Streambed sediment } \\
\text { samples }\end{array}$} & \multicolumn{6}{|c|}{ Lake-bottom sediment samples } \\
\hline & \multirow[b]{2}{*}{$\begin{array}{l}\text { Mini- } \\
\text { mum }\end{array}$} & \multirow[b]{2}{*}{$\begin{array}{l}\text { Maxi- } \\
\text { mum }\end{array}$} & \multirow[b]{2}{*}{$\begin{array}{l}\text { Median } \\
\text { (n) }\end{array}$} & \multirow[b]{2}{*}{$\begin{array}{l}\text { Mini- } \\
\text { mum }\end{array}$} & \multirow[b]{2}{*}{$\begin{array}{l}\text { Maxi- } \\
\text { mum }\end{array}$} & \multirow[b]{2}{*}{$\begin{array}{l}\text { Median } \\
\text { (n) }\end{array}$} & \multicolumn{3}{|c|}{ Core sediment } & \multicolumn{3}{|c|}{ Surficial bottom sedimen } \\
\hline & & & & & & & $\begin{array}{c}\text { Mini- } \\
\text { mum }\end{array}$ & $\begin{array}{c}\text { Maxi- } \\
\text { mum }\end{array}$ & $\begin{array}{c}\text { Median } \\
\text { (n) }\end{array}$ & $\begin{array}{l}\text { Mini- } \\
\text { mum }\end{array}$ & $\begin{array}{c}\text { Maxi- } \\
\text { mum }\end{array}$ & $\begin{array}{c}\text { Median } \\
\text { (n) }\end{array}$ \\
\hline \multicolumn{13}{|c|}{ RPDs from this study } \\
\hline PCB Aroclors & 6 & 34 & $26(2)$ & 0 & 40 & $15(3)$ & 14 & 61 & $19(2)$ & 0 & 46 & $8(2)$ \\
\hline PCB congeners & 0 & 33 & $10(2)$ & 0 & 55 & $27(3)$ & 0 & 94 & $24(2)$ & 0 & 26 & $7(2)$ \\
\hline \multicolumn{13}{|c|}{ RPDs from Besse and others (2005) } \\
\hline PCB Aroclors & 70 & 80 & ${ }^{1} 75(1)$ & 0 & 87 & ${ }^{1} 13(6)$ & 0 & 16 & ${ }^{1} 12(4)$ & 26 & 29 & $28(1)$ \\
\hline PCB congeners & 5 & 133 & $136(1)$ & 0 & 130 & $125(6)$ & 0 & 156 & ${ }^{1} 12(4)$ & 0 & 70 & $21(1)$ \\
\hline
\end{tabular}

'Besse and others (2005, table 3).

samples collected for this report were not analyzed for ${ }^{137} \mathrm{Cs}$ to recalculate MARs and deposition dates because limited depth intervals were sampled. Instead, the MARs calculated for the most recently deposited sediments in the 2003 gravity cores were used in conjunction with the sediment porosity and mass of the 2006 box cores to estimate age dates. A constant MAR was assumed for each 2006 box core. Table 2 lists the porosities, MARs, and estimated deposition dates for the lakebottom sediment samples collected in 2003 and 2006.

\section{Degree of Contamination and Sources of Polychlorinated Biphenyls}

Concentrations of total PCBs in suspended, streambed, and lake-bottom sediment samples were compared to consensus-based sediment quality guidelines (SQGs) of MacDonald and others (2000) to provide a general indication of the degree of contamination. Two consensus-based SQGs are defined: the threshold effect concentration (TEC) and the probable effect concentration (PEC). The TEC is the concentration below which adverse effects to benthic biota rarely occur, and the PEC is the concentration above which adverse effects to benthic biota are expected to occur frequently (MacDonald and others, 2000). The SQGs were derived through various laboratory, field, and theoretical methods and are not definitive for determining sediment toxicity to benthic biota nor are they to be extrapolated to assess adverse effects to fish, aquatic plants, or humans (Long and others, 1995; MacDonald and others, 2000). Although the SQGs provide a general indication of the degree of contamination, they do not provide a benchmark for concern for accumulation in fish or for human health risk associated with eating fish.
Total PCBs were computed in two ways: as the sum of the three Aroclors $\left(\Sigma \mathrm{PCB}_{\mathrm{A}}\right)$ or as the sum of the 27 reported congeners $\left(\Sigma \mathrm{PCB}_{\mathrm{C}}\right)$. Estimated concentrations were used as reported, and nondetections were treated as zeros in the computation of $\Sigma \mathrm{PCB}_{\mathrm{A}}$ and $\Sigma \mathrm{PCB}_{\mathrm{C}}$. The $\Sigma \mathrm{PCB}_{\mathrm{A}}$ typically is larger than $\Sigma \mathrm{PCB}_{\mathrm{C}}$ for the following reasons: First, only 27 of 209 possible congeners are analyzed for by the USGS NWQL, so $\Sigma \mathrm{PCB}_{\mathrm{C}}$ accounts for only 13 percent of total possible congeners. Second, individual congeners are present at much lower concentrations than Aroclors, so it is more likely that individual congeners will not be detected. Detection frequencies for the 27 PCB congeners analyzed for in this report varied by the degree of chlorination and by sample type. In general, detection frequency increased with increasing degree of chlorination and was higher in surficial lake-bottom sediment samples than in suspended and streambed sediment samples (appendix 2).

The concentrations of $\Sigma \mathrm{PCB}_{\mathrm{A}}$ and $\Sigma \mathrm{PCB}_{\mathrm{C}}$ in suspended, streambed, and lake-bottom sediment samples are compared to the TEC for total PCB $(59.8 \mu \mathrm{g} / \mathrm{kg}$ ) (MacDonald and others, 2000) in figure 5; nondetections were treated as zeros. Samples with ratios greater than 1 in figure 5 contain concentrations that exceed the TEC. Suspended sediment concentrations exceed the TEC for 76 percent of the samples when comparing the $\Sigma \mathrm{PCB}_{\mathrm{A}}$ to the TEC and for 41 percent of the samples when comparing the $\Sigma \mathrm{PCB}_{\mathrm{C}}$ to the TEC. The concentrations of $\Sigma \mathrm{PCB}_{\mathrm{A}}$ for 24 percent of the suspended sediment samples exceed the PEC for total PCBs $(676 \mu \mathrm{g} / \mathrm{kg})$. There are fewer streambed and lake-bottom sediment samples than suspended sediment samples with total PCB concentrations greater than the TEC and none are greater than the PEC. $\Sigma \mathrm{PCB}_{\mathrm{A}}$ concentrations in streambed sediment samples exceed the TEC for 33 percent of the samples, and $\mathrm{PCB}_{\mathrm{C}}$ in streambed sediment samples exceed the TEC for 17 percent of the 
Table 2. Porosities, mass accumulation rates, and estimated deposition dates for 2006 lake-bottom sediment samples and 2003 gravity core samples from Woods Inlet of Lake Worth, Fort Worth, Texas.

[ID, identifier; cm, centimeter; MAR, mass accumulation rate; $\mathrm{g} / \mathrm{cm}^{2}$-yr, grams per square centimeter per year]

\begin{tabular}{|c|c|c|c|c|c|c|}
\hline $\begin{array}{l}\text { Collection } \\
\text { date }\end{array}$ & $\begin{array}{l}\text { Sample ID } \\
\text { and interval } \\
\text { (cm) }\end{array}$ & $\begin{array}{l}\text { Mid-depth } \\
\quad \text { (cm) }\end{array}$ & $\begin{array}{l}\text { Thickness } \\
\text { (cm) }\end{array}$ & Porosity & $\begin{array}{c}\text { MAR } \\
\left(\mathrm{g} / \mathrm{cm}^{2}-\mathrm{yr}\right)\end{array}$ & $\begin{array}{c}\text { Estimated } \\
\text { deposition date } \\
\text { (year) }\end{array}$ \\
\hline \multirow[t]{5}{*}{2006} & WWD.1 0-1 & 0.5 & 1 & 0.91 & 0.6 & 2006.5 \\
\hline & WWD.1 1-3 & 2 & 2 & .91 & .6 & 2006.0 \\
\hline & WWD.1 3-5 & 4 & 2 & .86 & .6 & 2005 \\
\hline & WWD.1 5-10 & 7.5 & 5 & .89 & .6 & 2004 \\
\hline & WWD.1 10-15 & 12.5 & 5 & .79 & .6 & 2001 \\
\hline \multirow[t]{6}{*}{2003} & WWD1 (0-5) & 2.5 & 5 & .87 & .62 & 2002 \\
\hline & WWD1 (5-10) & 7.5 & 5 & .79 & .64 & 1999 \\
\hline & WWD1 (10-20) & 12.5 & 10 & .81 & .68 & 1994 \\
\hline & WWD1 (20-30) & 25 & 10 & .80 & .72 & 1988 \\
\hline & WWD1 (30-40) & 35 & 10 & .79 & .76 & 1982 \\
\hline & WWD1 (40-50) & 45 & 10 & .77 & .81 & 1976 \\
\hline \multirow[t]{5}{*}{2006} & WWD.2 0-1 & .5 & 1 & .81 & .7 & 2006.4 \\
\hline & WWD.2 1-3 & 2 & 2 & .74 & .7 & 2005 \\
\hline & WWD.2 3-5 & 4 & 2 & .84 & .7 & 2004 \\
\hline & WWD.2 5-10 & 7.5 & 5 & .68 & .7 & 2001 \\
\hline & WWD.2 10-15 & 12.5 & 5 & .68 & .7 & 1996 \\
\hline \multirow[t]{6}{*}{2003} & WWD2 (0-5) & 2.5 & 5 & .79 & .74 & 2002 \\
\hline & WWD2 (5-10) & 7.5 & 5 & .80 & .77 & 1999 \\
\hline & WWD2 (10-20) & 15 & 10 & .80 & .82 & 1994 \\
\hline & WWD2 (20-30) & 25 & 10 & .75 & .88 & 1988 \\
\hline & WWD2 (30-40) & 35 & 10 & .75 & .95 & 1982 \\
\hline & WWD2 (40-50) & 45 & 10 & .71 & 1.03 & 1976 \\
\hline \multirow[t]{5}{*}{2006} & WWD.3 0-1 & .5 & 1 & .80 & .65 & 2006.4 \\
\hline & WWD.3 1-3 & 2 & 2 & .75 & .65 & 2005 \\
\hline & WWD.3 3-5 & 4 & 2 & .71 & .65 & 2004 \\
\hline & WWD.3 5-10 & 7.5 & 5 & .66 & .65 & 2001 \\
\hline & WWD.3 10-13 & 11.5 & 3 & .65 & .65 & 1996 \\
\hline \multirow[t]{6}{*}{2003} & WWD3 (0-5) & 2.5 & 5 & .76 & .67 & 2001 \\
\hline & WWD3 (5-10) & 7.5 & 5 & .65 & .71 & 1996 \\
\hline & WWD3 (10-20) & 15 & 10 & .70 & .76 & 1988 \\
\hline & WWD3 (20-30) & 25 & 10 & .71 & .83 & 1979 \\
\hline & WWD3 (30-40) & 35 & 10 & .71 & .90 & 1971 \\
\hline & WWD3 (40-50) & 45 & 10 & .69 & .97 & 1964 \\
\hline
\end{tabular}



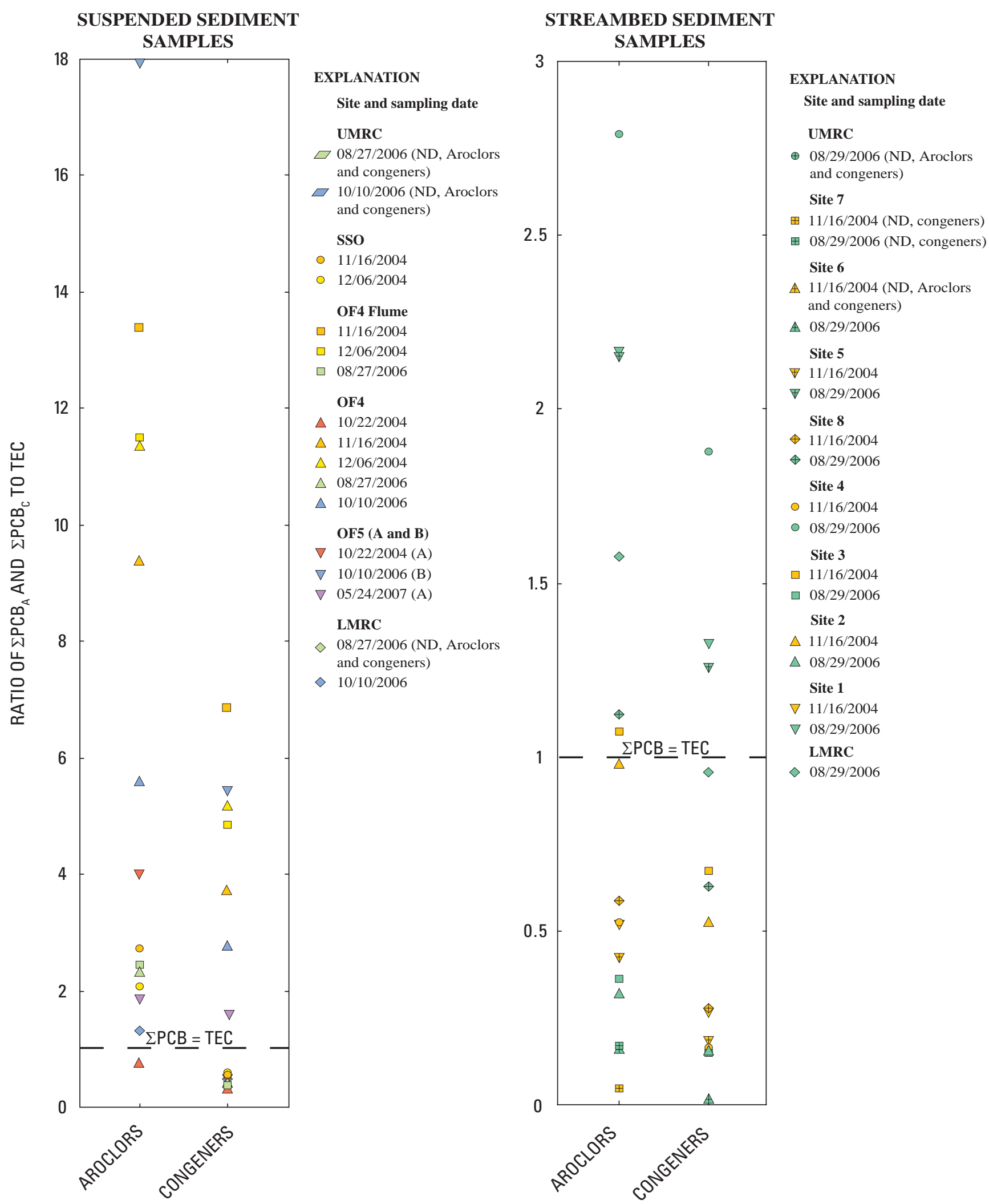

ND Nondetection at laboratory reporting level

Figure 5. Ratios of total polychlorinated biphenyl (PCB) concentrations (as sum of three Aroclors $\left[\Sigma P C B_{A}\right]$ and as sum of 27 reported congeners $\left[\Sigma P C B_{C}\right]$ ) to threshold effect concentration (TEC), a consensus-based sediment quality guideline (MacDonald and others, 2000) for suspended, streambed, and lake-bottom sediment samples collected from Meandering Road Creek and Woods Inlet of Lake Worth, Fort Worth, Texas, 2004 and 2006-07. 


\section{LAKE-BOTTOM SEDIMENT SAM PLES - BOX CORES}

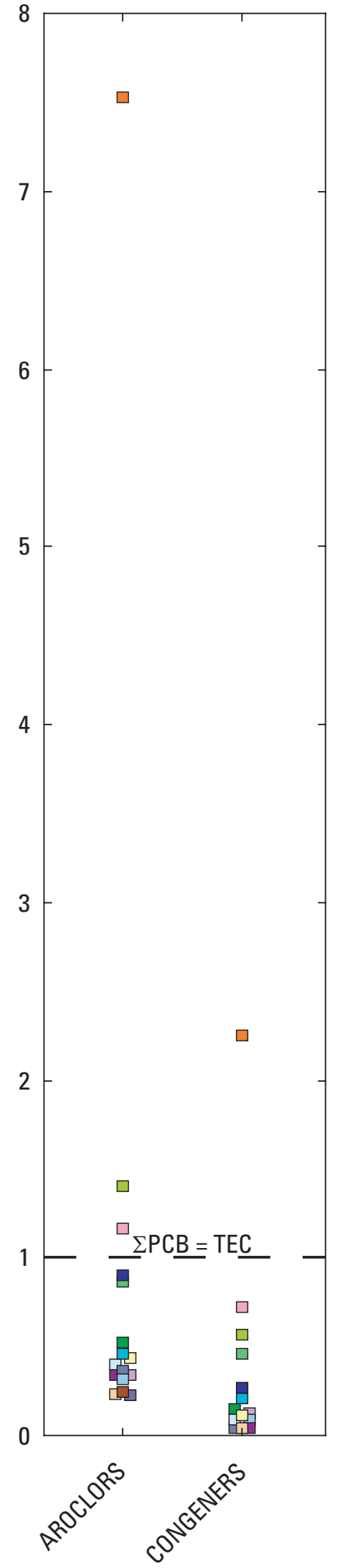

LAKE-BOTTOM SE DIMENT SAM PLES - BOX CORE S COLLECTED AT 2003 GRAVITY CORE SITES

EXPLANATION

Site and identifier

$\square$ B1

$\square$ B2

$\square$ B3

$\square$ B4

$\square$ B5

$\square$ B6

$\square$ B7

$\square$ B8

$\square$ B9

口 B10

$\square$ B 11

— B12

口 B13 (ND, congeners)

B14

口 B15 (ND, Aroclors and congeners)

ㅁ B16

口 B17 (ND, congeners) Note: Prefix “WWD." not shown.

Symbols offset for illustrative purposes. All samples collected 08/26/2006.

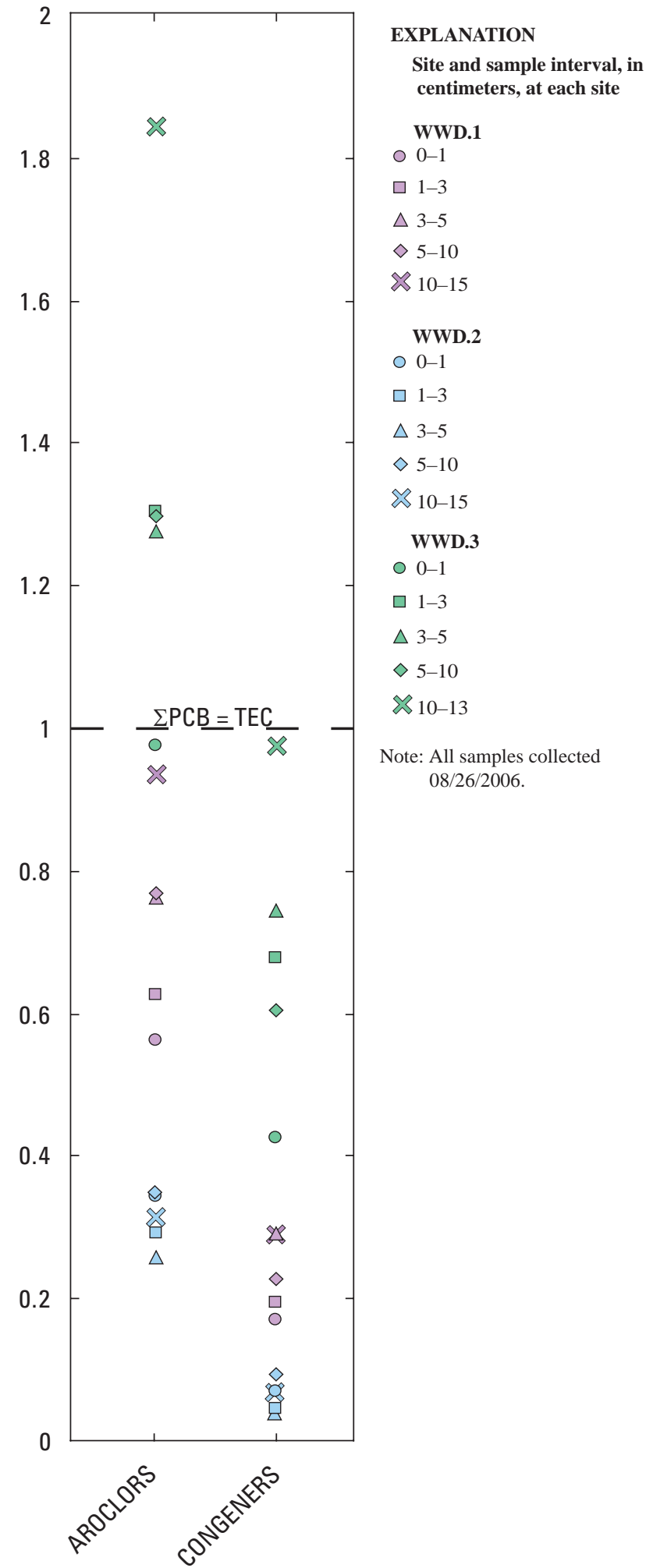

Figure 5.-Continued. 
samples. $\Sigma \mathrm{PCB}_{\mathrm{A}}$ and $\Sigma \mathrm{PCB}_{\mathrm{C}}$ concentrations in lake-bottom sediment samples exceed the TEC for 22 and 3 percent of the samples, respectively.

Potential sources of PCBs include historical landfills or historically contaminated soils on AFP4 and point or nonpoint sources in the surrounding urban area. Total PCB concentrations in suspended and streambed sediment samples varied greatly among sites and indicate likely sources of PCBs associated with sites SSO, OF4, and OF5, which receive runoff from AFP4 (fig. 6; appendix 2). Because runoff entering Meandering Road Creek from some parts of AFP4 was not sampled for this report, sites SSO, OF4, and OF5 might not be the only sources of PCBs from AFP4 to Meandering Road Creek and Woods Inlet of Lake Worth. For UMRC, the site receiving drainage from the surrounding urban area but not influenced by runoff from AFP4, no PCB congeners were detected in any of the three samples (one streambed sediment and two suspended sediment) collected there. In contrast, the two suspended sediment samples from SSO contained $\Sigma \mathrm{PCB}_{\mathrm{C}}$ concentrations (estimated) of 32 and $37 \mu \mathrm{g} / \mathrm{kg}$; the five suspended sediment samples from OF4 contained $\Sigma \mathrm{PCB}_{\mathrm{C}}$ concentrations (estimated) of 18, 220, 310, 25, and $160 \mu \mathrm{g} / \mathrm{kg}$; and the three suspended sediment samples from OF5 contained $\Sigma \mathrm{PCB}_{\mathrm{C}}$ concentrations (estimated) of 29,330 , and $93 \mu \mathrm{g} / \mathrm{kg}$. The two suspended sediment samples from LMRC, influenced by flow at UMRC, SSO, OF4, and OF5 (AFP4 runoff), yielded $\Sigma \mathrm{PCB}_{\mathrm{C}}$ concentrations of no detection (less than $27 \mu \mathrm{g} / \mathrm{kg}$ ) and $29 \mu \mathrm{g} / \mathrm{kg}$ (estimated).

Because PCBs are hydrophobic, the primary way for them to enter urban creeks and lakes is erosion and fluvial transport attached to sediment. The most likely way for them to enter Woods Inlet is on suspended sediment in storm runoff that is directed to Woods Inlet by Meandering Road Creek.

The sources of PCBs to Meandering Road Creek and Woods Inlet were investigated by comparing the relative distributions of PCB congeners of suspended sediment to those of streambed and lake-bottom sediment. Congener assemblages can be indicative of different PCB sources (Colman, 2000; Johnson and others, 2000; Cacela and others, 2002). PCB congener distributions were not examined for lake-bottom sediment samples deeper than $1.5 \mathrm{~cm}$ from sites WWD.1, WWD.2, and WWD. 3 because the deeper sediments were deposited before the suspended and streambed samples collected in 2006 (table 2). Samples with numerous nondetections also were excluded because of their limited use for comparison purposes. PCB congener distributions were determined by normalizing individual congener concentrations with $\Sigma \mathrm{PCB}_{\mathrm{C}}$ (dividing individual congener concentrations by $\Sigma \mathrm{PCB}_{\mathrm{C}}$ ). The assumption was made that relative concentrations of PCB congeners do not change appreciably (that is, no degradation or desorption of selected congeners) during transport and deposition, except by mixing.

The sources of PCBs were identified using graphical analysis of normalized concentrations (congener ratios) of 11 selected congeners (figs. 7-9). The 11 congeners were selected on the basis of their detection frequency, range of chlorina- tion, concentrations, and concentration variation between sites. For graphical analysis, the sampling sites were divided into three groups with each group associated with one of the three outfalls sampled: SSO, OF4, and OF5. The groupings were generally based on proximity of creek and inlet sites to the outfalls. The variations of normalized PCB congener concentrations from Woods Inlet, from outfalls along Meandering Road Creek, and from streambed sediment sampling sites along Meandering Road Creek generally form similar patterns within sample groups, which is indicative of a common source of PCBs to each group.

The first of these three groups is associated with SSO (fig. 7) and includes the suspended sediment site SSO and streambed sediment sites 4,5 , and 8 . The SSO group shows a congener ratio pattern dominated by the hexachlorobiphenyl congener 138 and to a lesser extent the pentachlorobiphenyl congeners 110 and 118 . The more highly chlorinated heptachlorbiphenyl congeners, such as 170, 180, and 187, were either not detected or were detected at much lower concentrations.

The second group is associated with OF4 (fig. 8) and includes suspended sediment sites OF4 and OF4 Flume (which drains directly to OF4) and streambed sediment sites 1, 2 , and 3 . This group shows a distinctly different congener ratio pattern compared to the SSO group, specifically an increasing degree of chlorination. Congener 110 is slightly less prominent, and congeners 170,180, and 187 are more prominent. This trend is not apparent for site 3 , which seems to more closely resemble the SSO group; but this is not unexpected because site 3 is upstream from OF4 and was included in the OF4 group on the basis of geographic proximity.

The third group is associated with OF5 (fig. 9) and includes suspended sediment site OF5 (sampled at OF5A and OF5B), suspended and streambed sediment site LMRC, and four groups of lake-bottom sediment sites associated with four regions of Woods Inlet. The Gruggs arm of Woods Inlet contains WWD.2, B1, B2, and B3; the TNG arm includes B4 and B5; the Meandering Road Creek arm includes WWD.3, B6, B7, B8, and B9; and the middle of Woods Inlet contains WWD.1, B10, B11, and B12. The congener ratio patterns of the OF5 group do not show any trend common to the entire group. The OF5A and OF5B samples are characterized predominantly by the more highly chlorinated $\mathrm{PCB}$ congeners $(170,180$, and 187). PCB congeners such as 110, 118, and 138 that were more prevalent at outfalls farther upstream (SSO and OF4) were either not detected for OF5 or detected at much lower concentrations, resulting in smaller ratios. The OF5 pattern does not carry over to the inlet sites. However, the congener ratio pattern for LMRC, the creek site closest to the Meandering Road Creek arm of Woods Inlet, is almost identical to the congener ratio pattern for the Meandering Road Creek arm of the inlet.

Overall, the variations in congener ratios indicate that PCBs in surficial lake-bottom sediment of Woods Inlet probably entered Woods Inlet primarily from Meandering Road Creek, and that runoff from AFP4 is a prominent 


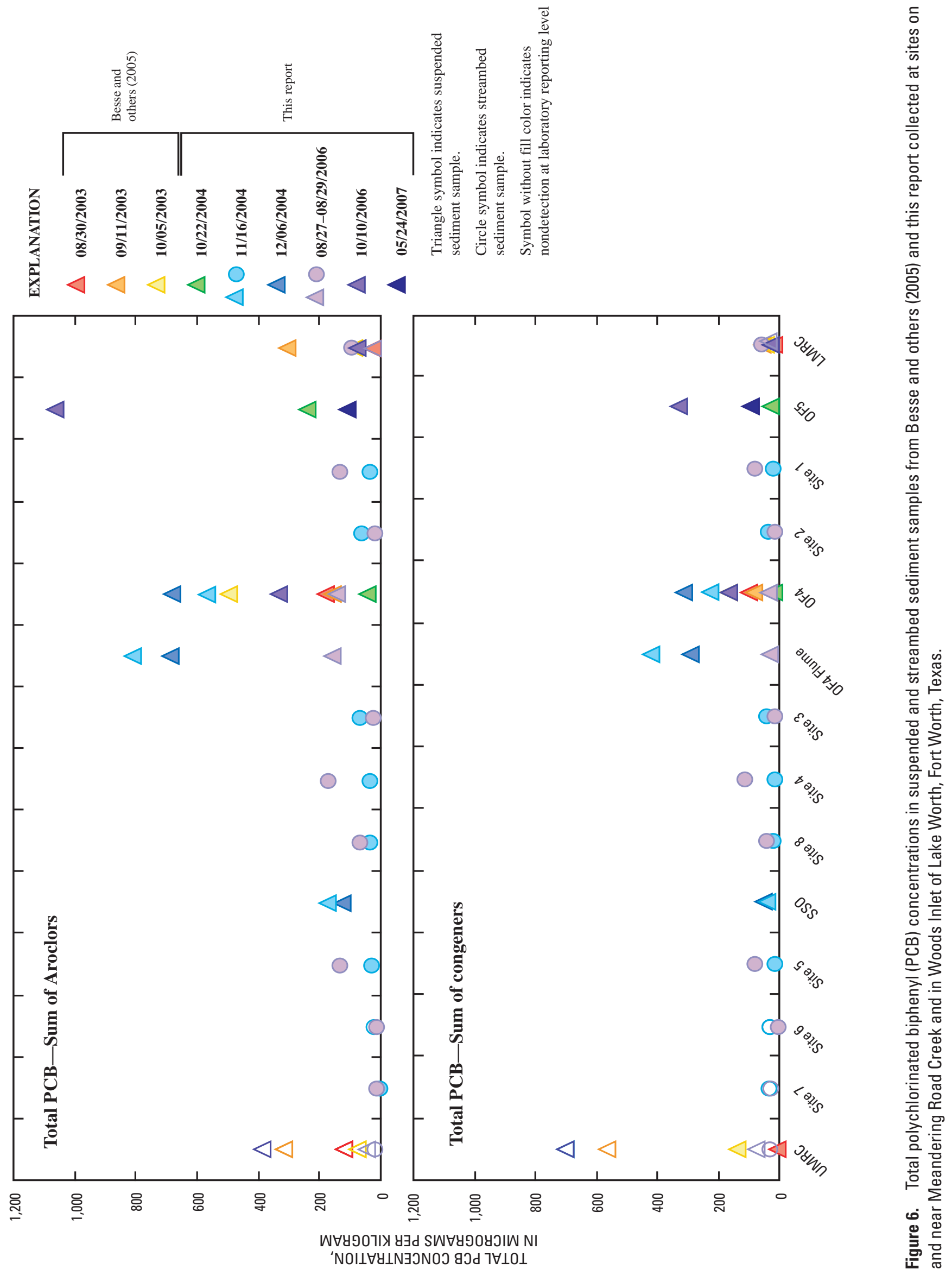




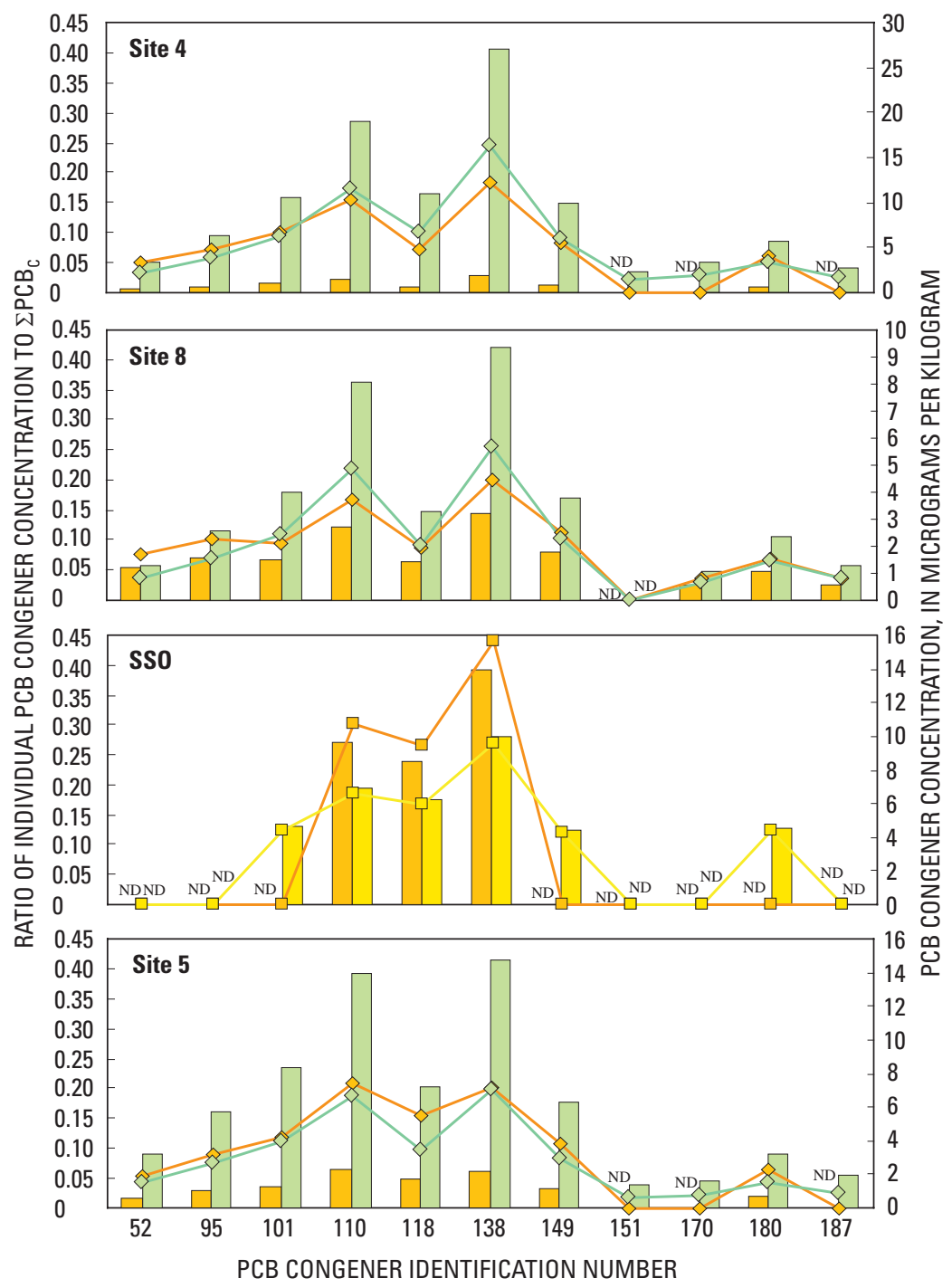

EXPLANATION

RATIO OF INDIVIDUAL CONGENER CONCENTRATION TO $\Sigma$ PCB $B_{c}$

\section{Line graph symbol and}

corresponding sampling date

$\leadsto$ Streambed sediment 11/16/2004

$\checkmark$ Streambed sediment 08/29/2006

$\longrightarrow \square$ Suspended sediment 11/16/2004

$\square$ - Suspended sediment 12/06/2004

PCB CONGENER CONCENTRATION, STREAMBED OR SUSPENDED SEDIMENT, IN MICROGRAMS PER KILOGRAM

Bar graph symbol and corresponding sampling date

\section{$\square 11 / 16 / 2004$}

$\square 12 / 06 / 2004$

$\square 08 / 29 / 2006$

ND Nondetection at laboratory reporting level

Figure 7. Polychlorinated biphenyl (PCB) congener concentrations and ratio of individual PCB congener concentrations to the sum of PCB congeners $\left(\Sigma P C B_{C}\right)$ at sites 4, 5, and 8 sampled for streambed sediment and site SSO sampled for suspended sediment on or near Meandering Road Creek, Lake Worth, Fort Worth, Texas, 2004 and 2006. 


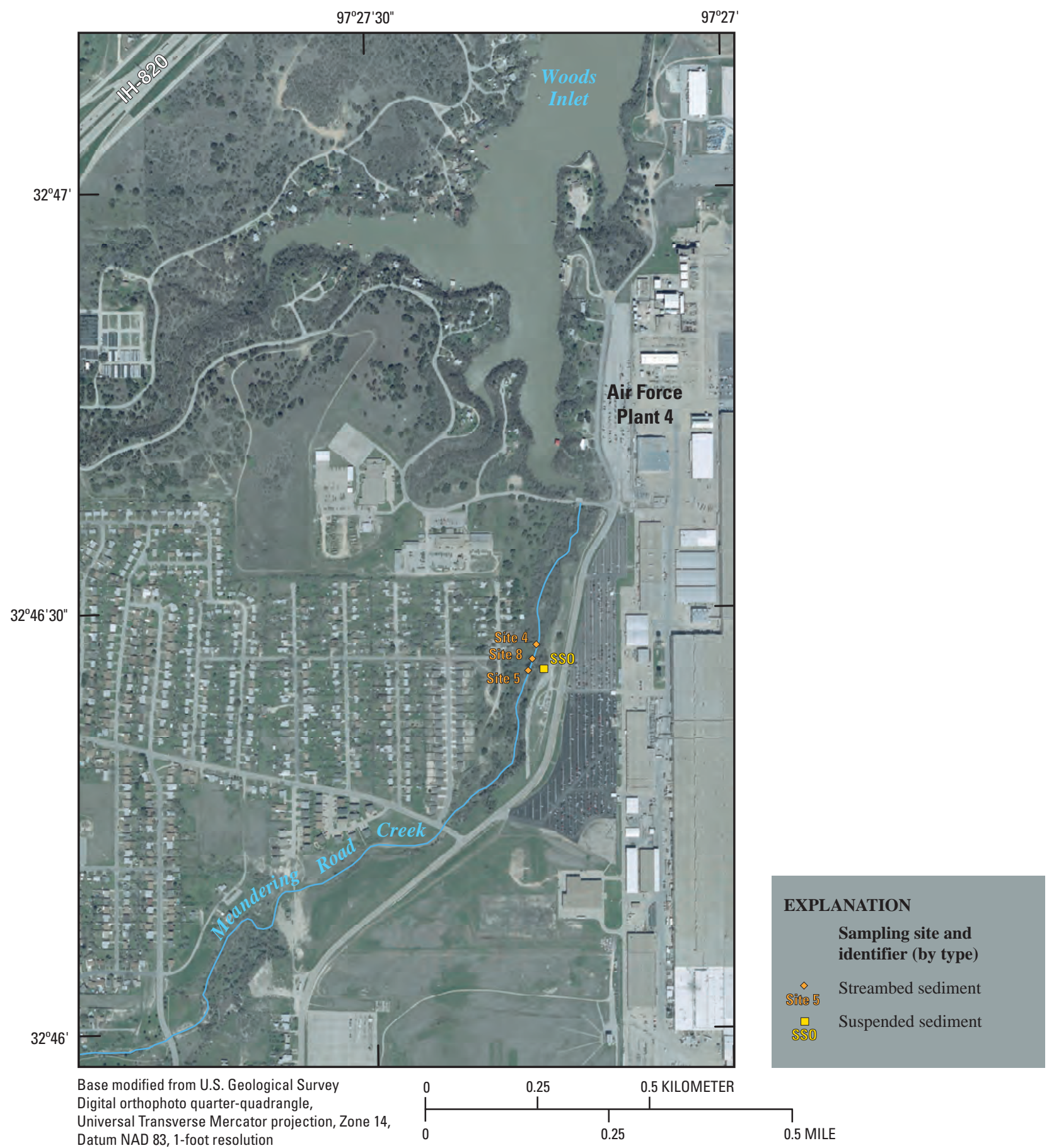

Figure 7.-Continued. 

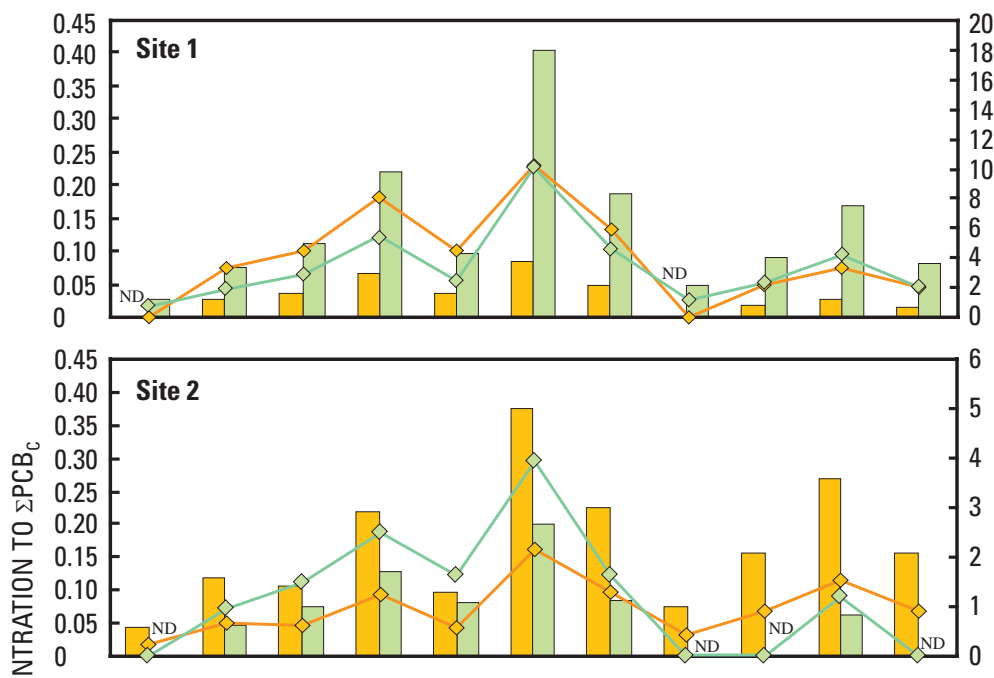

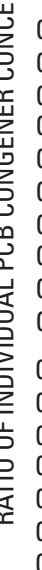

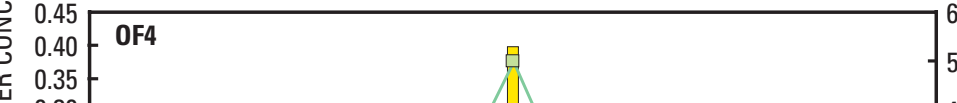

0.30

0.25

0.20

0.15

0.10

0.05
0

0.45

0.40 OF4 Flume

0.35

0.30

0.25

0.15

0.10

$0.05-\mathrm{ND}$ ND

0

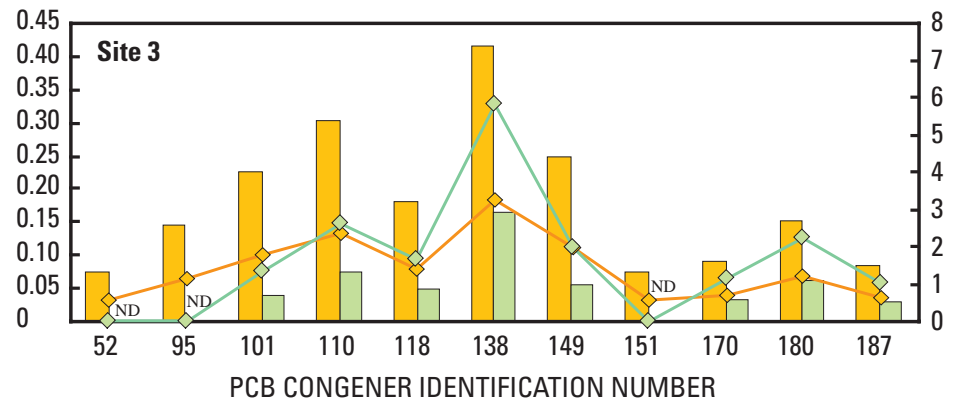

\section{EXPLANATION}

RATIO OF INDIVIDUAL CONGENER CONCENTRATION TO $\Sigma$ PCB

$L$ ine graph symbol and corresponding sampling date

$\smile$ Streambed sediment 11/16/2004

$\checkmark$ Streambed sediment 08/29/2006

$\longrightarrow$ Suspended sediment 10/22/2004

$\longrightarrow$ - Suspended sediment 11/16/2004

$\square-$ Suspended sediment 12/06/2004

$\square-$ Suspended sediment 08/27/2006

$\square-$ Suspended sediment 10/10/2006

PCB CONGENER CONCENTRATION, ST REAMBED OR SUSPE NDED SEDIMENT, IN MICROGRAMS

PER KILOGRAM

Bar graph symbol and corresponding sampling date

$\square$ 10/22/2004

$\square 11 / 16 / 2004$

$\square 12 / 06 / 2004$

$\square$ 08/29/2006 (streambed); 08/27/2006 (suspended)

$\square$ 10/10/2006

ND Nondetection at laboratory reporting level

Figure 8. Polychlorinated biphenyl (PCB) congener concentrations and ratio of individual PCB congener concentrations to the sum of PCB congeners ( PCBC) at sites 1, 2, and 3 sampled for streambed sediment and sites OF4 and OF4 Flume sampled for suspended sediment on or near Meandering Road Creek, Lake Worth, Fort Worth, Texas, 2004 and 2006. 


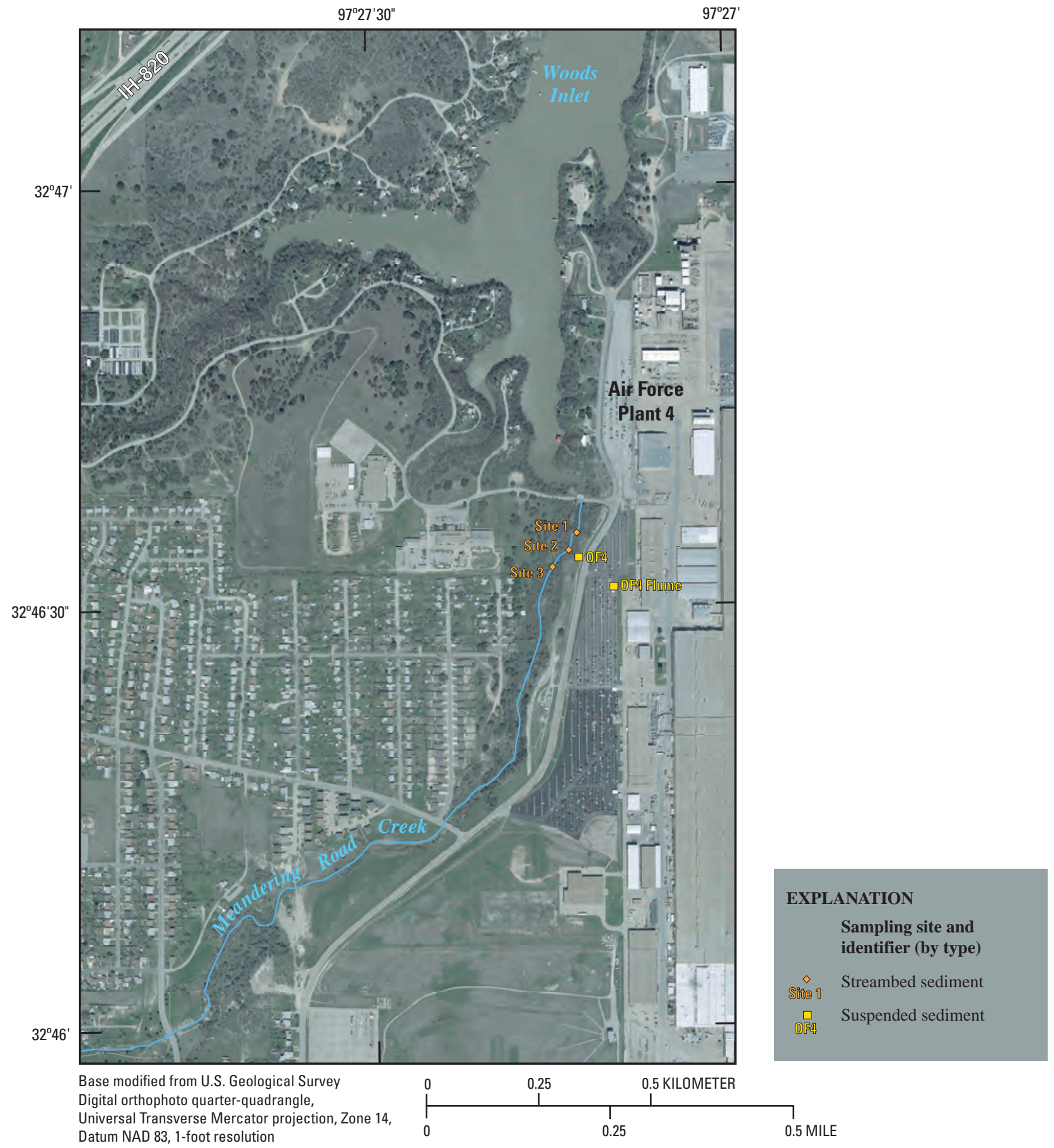

Figure 8. - Continued. 

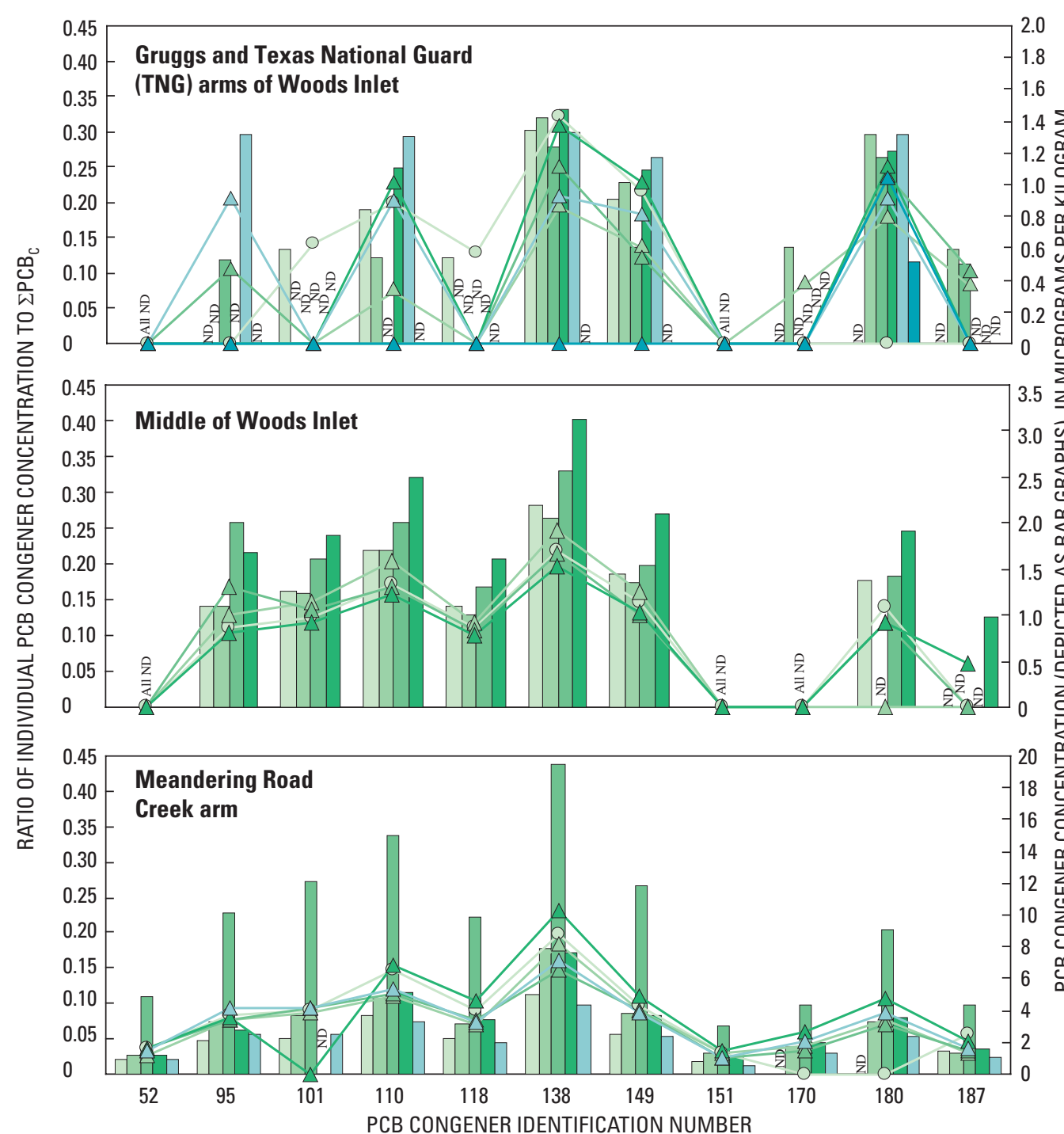

EXPLANATION

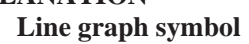
and corresponding lake-bottom
sediment sample Gruggs TNG

- WWD. $2 \triangle$ B4

$\triangle \mathrm{B} 1$

$\triangle B 3$

EXPLANATION

Line graph symbol and corresponding lake-bottom

sediment sample

- W WWD. 1

$\triangle \mathrm{B} 10$

$\triangle B 11$

$\triangle B 12$

\section{EXPLANATION}

Line graph symbol and corresponding

lake-bottom

sediment sample

- WWW 3

$\triangle B 6$

$\triangle B$ B7

$\triangle B 8$

$\triangle B 9$

\section{EXPLANATION PCB CONGENER CONCENTRATION LAKE BOTTOM SEDIMENT, IN MICROGRAMS PER} KILOGRAM

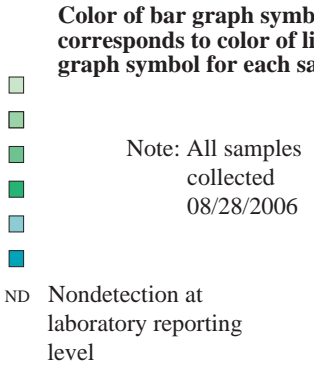

Figure 9. Polychlorinated biphenyl $(\mathrm{PCB})$ congener concentrations and ratio of individual PCB congener concentrations to the sum of PCB congeners $\left(\Sigma P C B_{C}\right)$ at 15 sites sampled for lake-bottom sediment (WWD.1-WWD.3 and WWD.B1-WWD.B12), site 0F5 sampled for suspended sediment, and site LMRC sampled for suspended and streambed sediment, Meandering Road Creek and Woods Inlet of Lake Worth, Fort Worth, Texas, 2004 and 2006-07. 

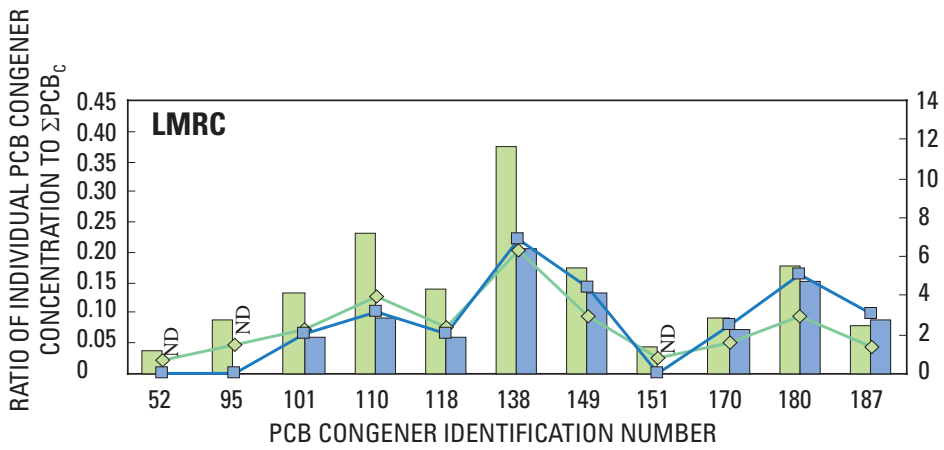

\section{EXPLANATION}

RATIO OF INDIVIDUAL CONGENER CONCENTRATION TO $\Sigma$ PCB Line graph symbol and corresponding sampling date

$\diamond$ Streambed sediment 08/29/2006

$\longrightarrow$ Suspended sediment 10/10/2006

\section{PCB CONGENER \\ CONCENTRATION, STREAMBED AND SUSPE NDE D SEDIMENT, IN MICROGRAMS PER KILOGRAM}

Bar graph symbol and corresponding sampling date

$\square$ 08/29/2006

$\square 10 / 10 / 2006$

ND Nondetection at laboratory reporting level

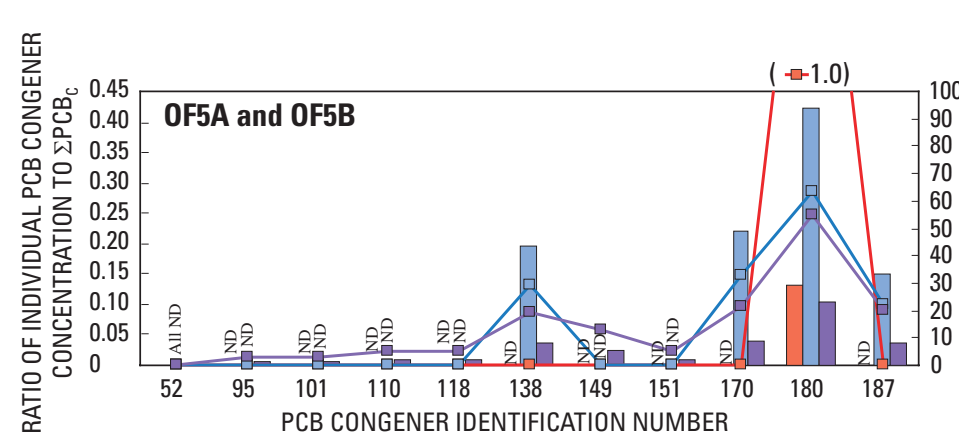

\section{EXPLANATION}

RATIO OF INDIVIDUAL CONGENER CONCEN TRATION TO $\triangle \mathrm{PCB}_{C}$ $L$ ine graph symbol and corresponding sampling date

$\longrightarrow$ - Suspended sediment 10/22/2004 (collected at OF5A)

$\square$ Suspended sediment 10/10/2006 (collected at OF5B)

$\rightarrow$ Suspended sediment 05/24/2007 (collected at OF5A)

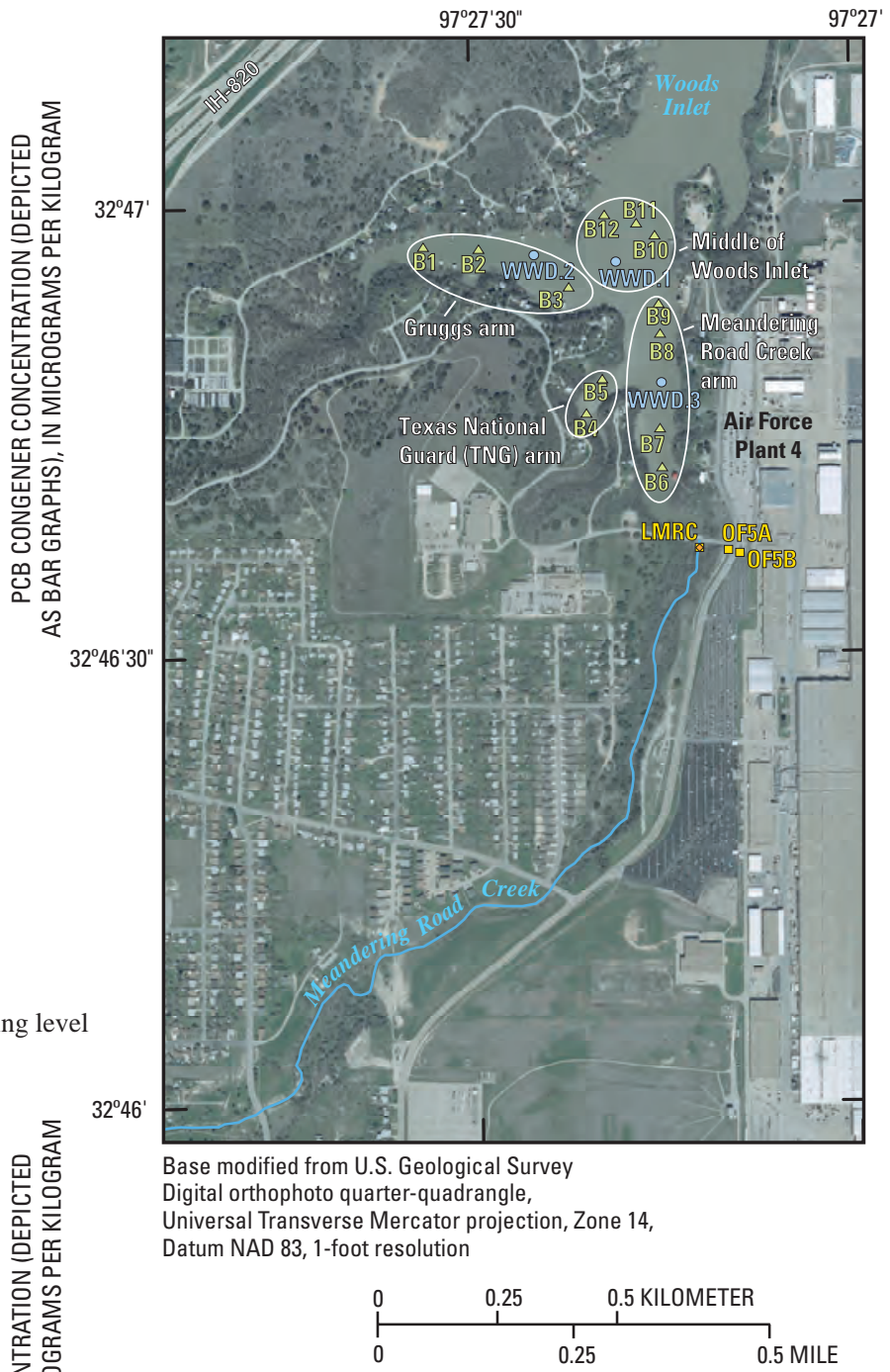

\section{EXPLANATION}

L ake-bottom sediment sampling site and site identifier

Box core (Prefix "WWD." not shown)

Box core collected at 2003 gravity core site

Suspended sediment sampling site and outfal site identifier

Suspended and streambed sediment sampling site and site identifier

Figure 9.-Continued. 
source of PCBs in Meandering Road Creek. Although current (2004-07) transport of PCBs from AFP4 to the creek is occurring, as OF4, OF4 Flume, OF5, and SSO sample analyses indicate, the decrease in PCB concentrations over time in the lake-bottom sediment samples collected in the 2003 gravity cores (WWD.1, WWD.2, and WWD.3) are evidence that PCB loading to the inlet has decreased since the 1960s. The downward trend in PCB concentrations at sites WWD. 1 and WWD. 3 continued between 2003 and 2006 while the trend generally changed little at site WWD.2, as demonstrated by results of analyses of box core samples collected in 2006 at the same sites (fig. 10).
Sixteen of the 20 box core sites in Woods Inlet had lower PCB concentrations in the 2006 cores compared to those in the 2003 cores (fig. 11). Of the four sites that showed an increase in total PCB concentrations between the 2003 and 2006 box cores, three were in the Meandering Road Creek arm of Woods Inlet and the fourth was in the middle of Woods Inlet. Comparing the 2003 and 2006 box cores, PCB concentrations did not increase in either the Gruggs or the Texas National Guard arms of Woods Inlet.

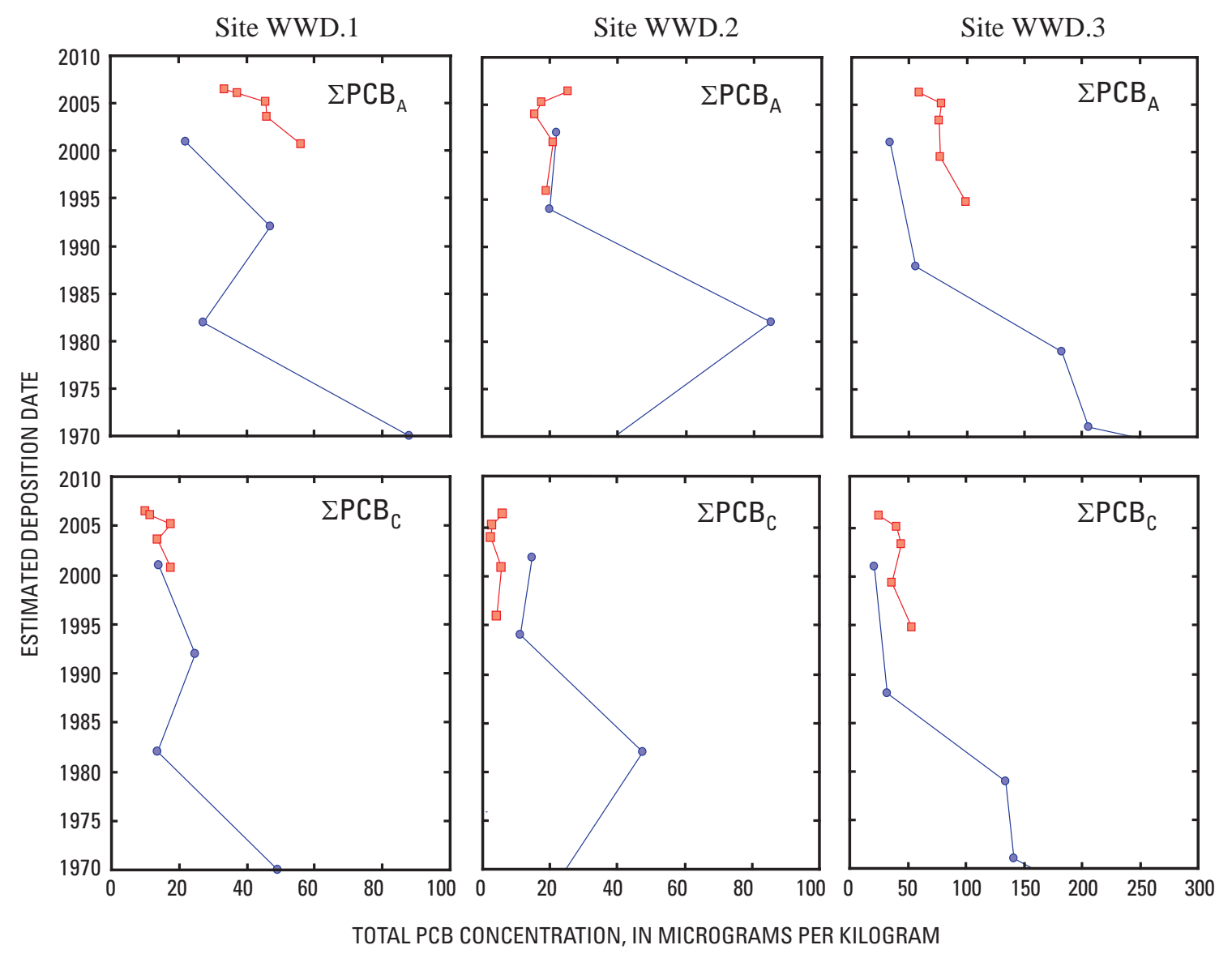

EXPLANATION

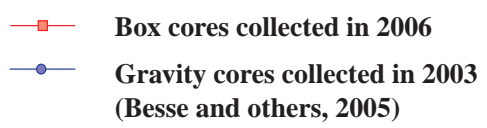

Figure 10. Total polychlorinated biphenyl (PCB) concentrations (as sum of PCB Aroclors $\left[\Sigma P_{C} B_{A}\right]$ and sum of $P C B$ congeners $\left[\Sigma P C B_{C}\right]$ ) and estimated deposition date for lake-bottom sediment samples from Woods Inlet of Lake Worth, Fort Worth, Texas, 2003 and 2006. 

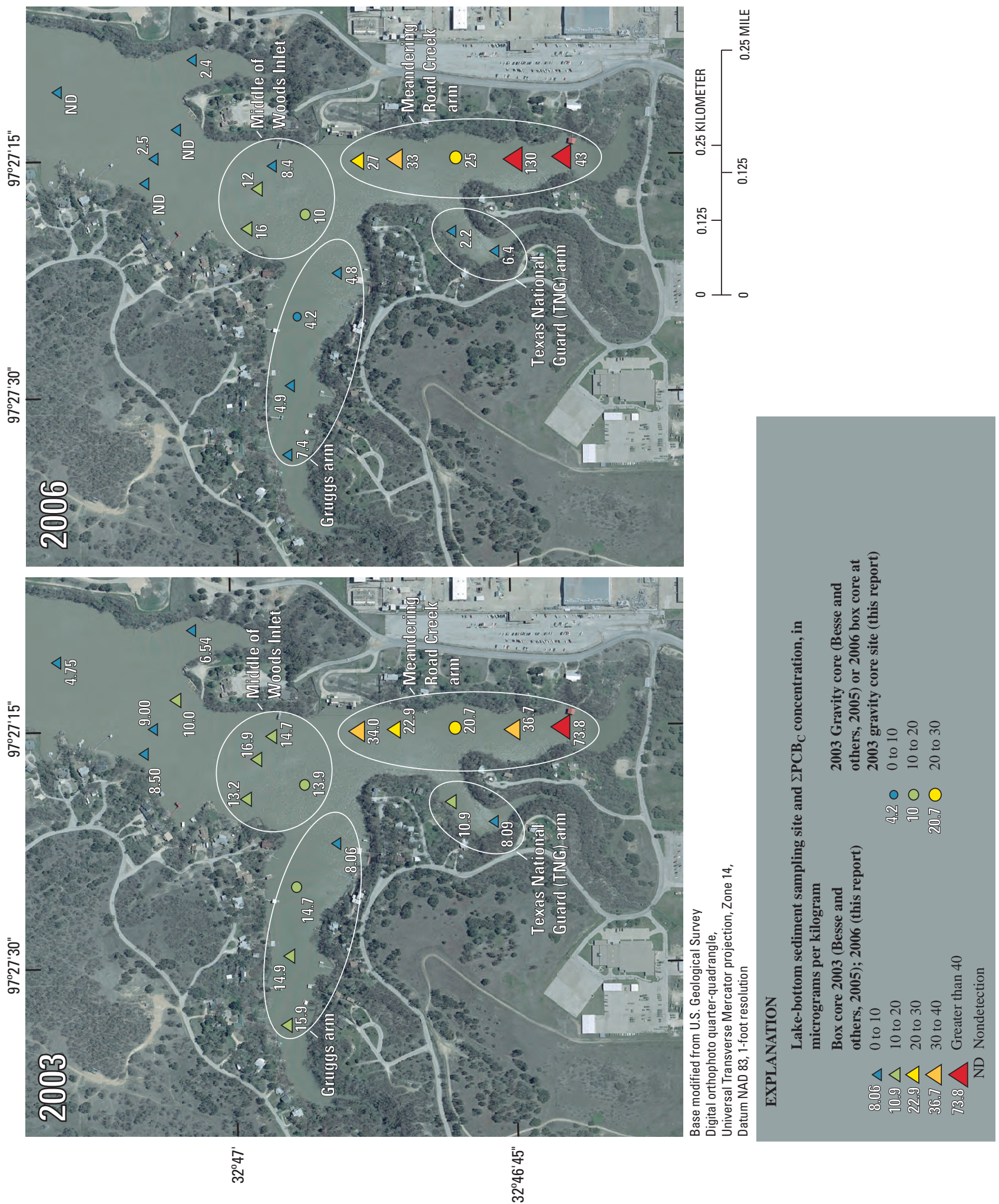

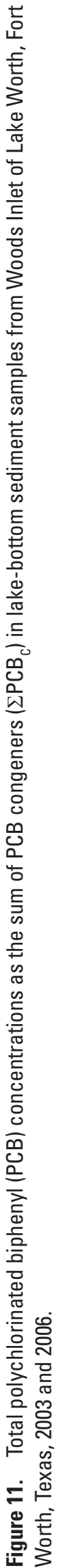




\section{Summary}

Lake Worth is a reservoir on the West Fork Trinity River on the western edge of Fort Worth, Texas. Air Force Plant 4 (AFP4) is on the eastern shore of Woods Inlet, an arm of Lake Worth that extends south from the main body of the lake. A previous USGS report in 2003 documented elevated polychlorinated biphenyl (PCB) concentrations in surficial sediment in Woods Inlet relative to those in surficial sediment in other parts of Lake Worth. A subsequent USGS report in 2005 indicated the highest PCB concentrations in Woods Inlet near the mouth of Meandering Road Creek. This report presents the results of another USGS study, done in cooperation with the U.S. Air Force, to indicate the degree of PCB contamination of Meandering Road Creek and Woods Inlet and to identify possible sources of PCBs in Meandering Road Creek and Woods Inlet on the basis of suspended, streambed, and lake-bottom sediment samples collected there in 2004 and 2006-07.

Concentrations of total PCBs in suspended, streambed, and lake-bottom sediment samples were compared to two consensus-based sediment quality guidelines to indicate the degree of contamination: the threshold effect concentration (TEC) and the probable effect concentration (PEC). The TEC is the concentration below which adverse effects to benthic biota rarely occur, and the PEC is the concentration above which adverse effects to benthic biota are expected to occur frequently.

Total PCBs were computed in two ways: as the sum of three widely used Aroclors $(1016 / 1242,1254,1260)\left(\Sigma \mathrm{PCB}_{\mathrm{A}}\right)$ or as the sum of 27 laboratory reported congeners $\left(\Sigma \mathrm{PCB}_{\mathrm{C}}\right)$. (PCBs are mixtures of a subset of as many as 209 theoretically possible chlorinated compounds, called congeners.) The $\Sigma \mathrm{PCB}_{\mathrm{A}}$ typically is larger than $\Sigma \mathrm{PCB}_{\mathrm{C}}$.

The concentrations of $\Sigma \mathrm{PCB}$ and $\Sigma \mathrm{PCB}_{\mathrm{C}}$ in suspended, streambed, and lake-bottom sediment samples were compared to the TEC for total PCB $(59.8 \mu \mathrm{g} / \mathrm{kg})$. Suspended sediment concentrations exceed the TEC for 76 percent of the samples when comparing the $\Sigma \mathrm{PCB}$ to the TEC and for 41 percent of the samples when comparing the $\Sigma \mathrm{PCB}_{\mathrm{C}}$ to the TEC. The concentration of $\Sigma \mathrm{PCB}_{\mathrm{A}}$ for 24 percent of the suspended sediment samples is greater than the PEC for total PCBs $(676 \mu \mathrm{g} / \mathrm{kg})$. There are fewer streambed and lake-bottom sediment samples than suspended sediment samples with total PCB concentrations greater than the TEC and none are greater than the PEC. $\Sigma \mathrm{PCB}_{\mathrm{A}}$ concentrations in streambed sediment samples exceed the TEC for 33 percent of the samples, and $\Sigma \mathrm{PCB}_{\mathrm{C}}$ in streambed sediment samples exceed the TEC for 17 percent of the samples. $\Sigma \mathrm{PCB}_{\mathrm{A}}$ and $\Sigma \mathrm{PCB}_{\mathrm{C}}$ concentrations in lake-bottom sediment samples exceed the TEC for 18 and 6 percent of the samples, respectively.

Potential sources of PCBs include historical landfills or historically contaminated soils on AFP4 and point or nonpoint sources in the surrounding urban area. Total PCB concentrations in suspended and streambed sediment samples varied greatly among sites and indicate likely sources of PCBs asso- ciated with sites SSO, OF4, and OF5, which receive runoff from AFP4. For UMRC, the site receiving drainage from the surrounding urban area but not influenced by runoff from AFP4, no PCB congeners were detected in any of the three samples (one streambed sediment and two suspended sediment) collected there.

The sources of PCBs to Meandering Road Creek and Woods Inlet were investigated by comparing the relative distributions of PCB congeners of suspended sediment to those of streambed and lake-bottom sediment. The sources of PCBs were identified using graphical analysis of normalized concentrations (congener ratios) of 11 congeners selected on the basis of their detection frequency, range of chlorination, concentrations, and concentration variation between sites. For graphical analysis, the sampling sites were divided into three groups with each group associated with one of the three outfalls sampled: SSO, OF4, and OF5. The variations of normalized PCB congener concentrations from Woods Inlet, from outfalls along Meandering Road Creek, and from streambed sediment sampling sites along Meandering Road Creek generally form similar patterns within sample groups, which is indicative of a common source of PCBs to each group. The SSO group shows a congener ratio pattern dominated by the hexachlorobiphenyl congener 138 and to a lesser extent the pentachlorobiphenyl congeners 110 and 118 . The OF4 group generally shows a distinctly different congener ratio pattern compared to the SSO group, specifically an increasing degree of chlorination in which congeners 170,180 , and 187 are more prominent. The congener ratio patterns of the OF5 group do not show any trend common to the entire group. However, the congener ratio pattern for LMRC, the creek site closest to the Meandering Road Creek arm of Woods Inlet, is almost identical to the congener ratio pattern for the Meandering Road Creek arm of the inlet. Overall, the variations in congener ratios indicate that PCBs in surficial lake-bottom sediment of Woods Inlet probably entered Woods Inlet primarily from Meandering Road Creek, and that runoff from AFP4 is a prominent source of PCBs in Meandering Road Creek.

Sixteen of the 20 box core sites in Woods Inlet had lower PCB concentrations in the 2006 cores compared to those in the 2003 cores. Of the four sites that showed an increase in total PCB concentrations between the 2003 and 2006 box cores, three were in the Meandering Road Creek arm of Woods Inlet.

\section{References}

Agency for Toxic Substances and Disease Registry, 2001, ToxFAQ for polychlorinated biphenyls (PCBs): accessed July 26, 2007, at http://www.atsdr.cdc.gov/tfacts17.pdf

Besse, R.E., Van Metre, P.C., and Wilson, J.T., 2005, Distribution and sources of polychlorinated biphenyls in Woods Inlet, Lake Worth, Fort Worth, Texas, 2003: U.S. Geological Survey Scientific Investigations Report 2005-5064, 40 p. 
Cacela, Dave, Beltman, D.J., and Lipton, Joshua, 2002, Polychlorinated biphenyl source attribution in Green Bay, Wisconsin, USA, using multivariate similarity among congener profiles in sediment samples: Environmental Toxicology and Chemistry, v. 21, no. 8, p. 1,591-1,599.

Callender, Edward, and Robbins, J.A., 1993, Transport and accumulation of radionuclides and stable elements in a Missouri River reservoir: Water Resources Research, v. 29, no. 6 , p. 1,787-1,804.

CH2M Hill, 1984, Installation restoration program records search for Air Force Plant 4: Contract report for U.S. Air Force [variously paged].

Colman, J.A., 2000, Source identification and fish exposure for polychlorinated biphenyls using congener analysis from passive water samplers in the Millers River Basin, Massachusetts: U.S. Geological Survey Water-Resources Investigations Report 00-4250, 44 p.

Connor, B.F., Rose, D.L., Noriega, M.C., Murtagh, L.K., and Abney, S.R., 1997, Methods of analysis by the U.S. Geological Survey National Water Quality Laboratory-Determination of 86 volatile organic compounds in water by gas chromatography/mass spectrometry, including detections less than reporting limits: U.S. Geological Survey Open-File Report 97-829, 78 p.

Earth Tech, Inc., 2005, West side DNAPL and PCB investigation at Air Force Plant 4, Fort Worth, Texas: Prepared for U.S. Air Force, Aeronautical Systems Center, Environmental Management Directorate, Wright-Patterson Air Force Base, Ohio, Contract No. F41624-00-D-8023 [variously paged].

Garcia, C.A., 2005, Subsurface occurrence and potential source areas of chlorinated ethenes identified using concentration and concentration ratios, Air Force Plant 4 and Naval Air Station-Joint Reserve Base Carswell Field, Fort Worth, Texas: U.S. Geological Survey Scientific Investigations Report 2005-5176, 81 p.

Harwell, G.R., Van Metre, P.C., Wilson, J.T., and Mahler, B.J., 2003, Spatial distribution and trends in trace elements, polycyclic aromatic hydrocarbons, organochlorine pesticides, and polychlorinated biphenyls in Lake Worth sediment, Fort Worth, Texas: U.S. Geological Survey Water-Resources Investigations Report 03-4269, 56 p.

International Technology Corporation, 2001, West side site investigation report, Air Force Plant 4, Fort Worth, Texas: Monroeville, Penn., International Technology Corporation, $110 \mathrm{p}$.

Johnson, G.W., Jarman, W.M., Bacon, C.E., Davis, J.A., Ehrlich, Robert, and Risebrough, R.W., 2000, Resolving polychlorinated biphenyl source fingerprints in suspended particulate matter of San Francisco Bay: Environmental Science and Technology, v. 34, no. 4, p. 552-559.
Long, E.R., MacDonald, D.D., Smith, S.L., and Calder, F.D., 1995, Incidence of adverse biological effects within ranges of chemical concentrations in marine and estuarine sediments: Environmental Management, v. 19, p. 81-97.

Long, G.R., Ayers, M.A., Callender, Edward, and Van Metre, P.C., 2003, Trends in chemical concentration in sediment cores from three lakes in New Jersey and one lake on Long Island, New York: U.S. Geological Survey Water-Resources Investigation Report 02-4272, 23 p.

MacDonald, D.D., Ingersoll, C.G., and Berger, T.A., 2000, Development and evaluation of consensus-based sediment quality guidelines for freshwater ecosystems: Archives of Environmental Contamination and Toxicology, v. 39, p. 20-31.

Mahler, B.J., and Van Metre, P.C., 2003, A simplified approach for monitoring hydrophobic organic contaminants associated with suspended sediments-Methodology and applications: Archives of Environmental Contamination and Toxicology, v. 44, no. 3, p. 288-297.

Moring, J.B., 2002, Data on occurrence of selected trace metals, organochlorines, and semivolatile organic compounds in edible fish tissues from Lake Worth, Fort Worth, Texas, 1999: U.S. Geological Survey Open-File Report 02-016, $23 \mathrm{p}$.

Noriega, M.C., Wydoski, D.S., and Foreman, W.T., 2003, Methods of analysis by the U.S. Geological Survey National Water Quality Laboratory-Determination of organochlorine pesticides and polychlorinated biphenyls in bottom and suspended sediment by gas chromatography with electroncapture detection: U.S. Geological Survey Water-Resources Investigations Report 03-4293, 46 p.

Olson, M.C., Iverson, J.L., Furlong, E.T., and Schroeder, M.P., 2004, Methods of analysis by the U.S. Geological Survey National Water Quality Laboratory-Determination of polycyclic aromatic hydrocarbon compounds in sediment by gas chromatography/mass spectrometry: U.S. Geological Survey Water-Resources Investigations Report 03-4318, $45 \mathrm{p}$.

RUST Geotech, 1995, Air Force Plant 4, remedial investigation and preliminary assessment/site inspection report, volume 1: Prepared for U.S. Air Force, Headquarters Aeronautical Systems Center, Wright-Patterson Air Force Base, Ohio, Department of Energy Contract No. DE-AC04-861D12584, GJPO-WMP-75, 545 p.

RUST Geotech, 1996, Final Record of Decision, Air Force Plant 4, Tarrant County, Texas: Prepared for U.S. Air Force, Headquarters Aeronautical Systems Center, Wright-Patterson Air Force Base, Ohio, Department of Energy Contract No. DE-AC04-94AL96907, GJPO-TP-11, 182 p.

Shelton, L.R., and Capel, P.D., 1994, Guidelines for collecting and processing samples of stream bed sediment for analysis 
of trace element and organic contaminants for the National Water-Quality Assessment Program: U.S. Geological Survey Open-File Report 94-0458, 20 p.

Smith, J.A., Witkowski, P.J., and Fusillo, T.V., 1988, Manmade organic compounds in the surface waters of the United States-A review of current understanding: U.S. Geological Survey Circular 1007, 92 p.

Texas Department of Health, 1998, Public health assessment, U.S. Air Force Plant No. 4 (General Dynamics), Fort Worth, Tarrant County, Texas: Comprehensive Environmental Response, Compensation, and Liability Information System, CERCLIS no. TX7572024605, 39 p.

Texas Department of Health, 2004, Fish consumption advisories and bans: accessed March 9, 2004, at http://www.tdh. state.tx.us/bfds/ssd

U.S. Environmental Protection Agency, 1990, National priorities list_-NPL site narrative for Air Force Plant \#4 (General
Dynamics): accessed November 18, 2003, at http://www. epa.gov/superfund/sites/npl/nar786.htm

Van Metre, P.C., Callender, Edward, and Fuller, C.C., 1997, Historical trends in organochlorine compounds in river basins identified using sediment cores from reservoirs: Environmental Science and Technology, v. 31, no. 8, p. 2,339-2,344.

Van Metre, P.C., Wilson, J.T., Callender, Edward, and Fuller, C.C., 1998, Similar rates of decrease of persistent, hydrophobic and particle-reactive contaminants in riverine systems: Environmental Science and Technology, v. 32, no. 21 , p. 3,312-3,317.

Van Metre, P.C., Wilson, J.T., Fuller, C.C., Callender, Edward, and Mahler, B.J., 2004, Collection, analysis, and agedating of sediment cores from 56 U.S. lakes and reservoirs sampled by the U.S. Geological Survey, 1992-2001: U.S. Geological Survey Scientific Investigations Report 2004-5184, 180 p. 
Appendixes 1-5 
Blank Page 


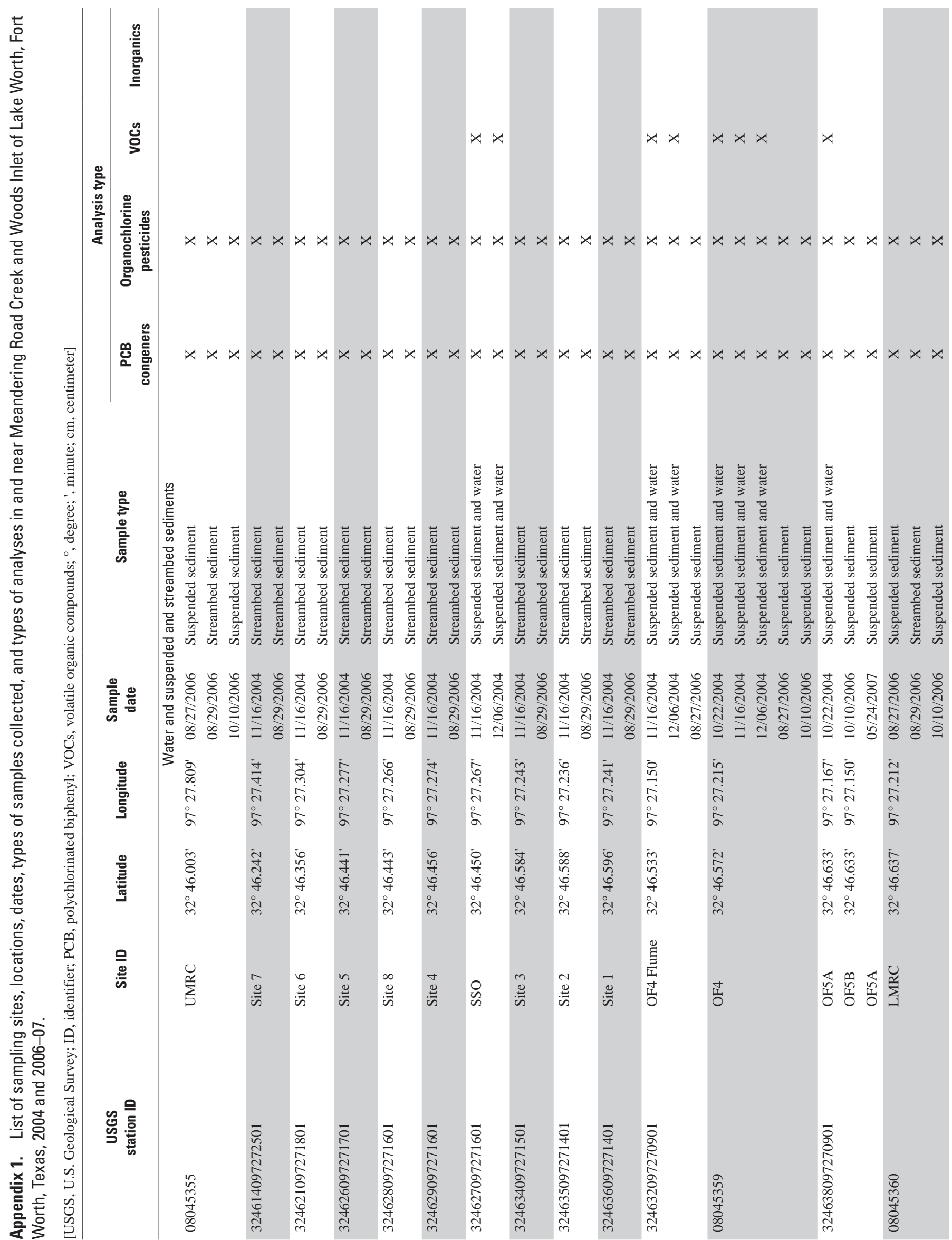




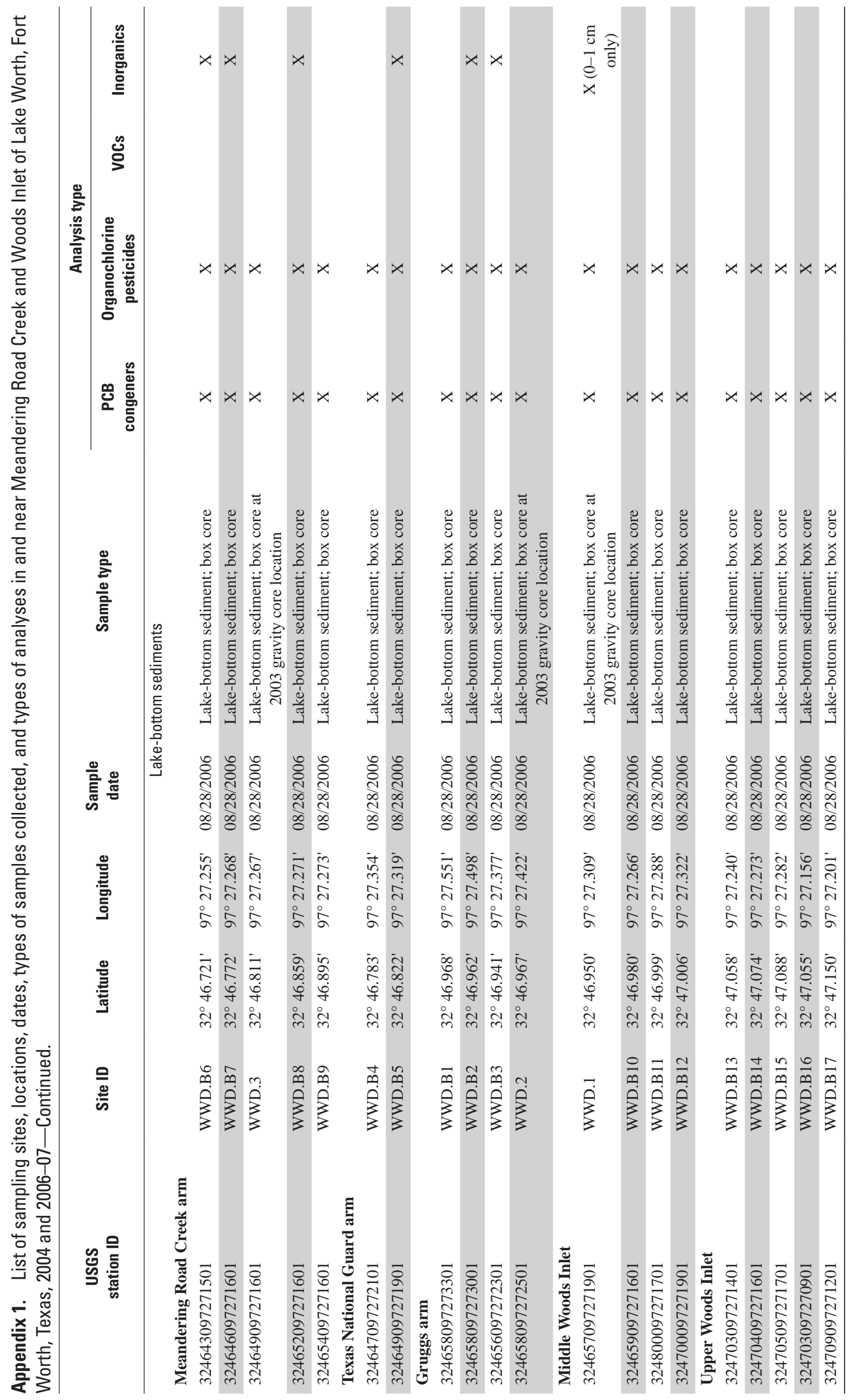


Appendix 2. Polychlorinated biphenyl (PCB) Aroclor and congener, organic carbon, and organochlorine pesticide concentrations in suspended, streambed, and lake-bottom sediment samples from sites in and near Meandering Road Creek and Woods Inlet of Lake Worth, Fort Worth, Texas, 2004 and 2006-07.

[In micrograms per kilogram except as noted. USGS, U.S. Geological Survey; ID, identifier; cm; centimeter; $\Sigma$, sum; n/a, not applicable; <, less than; E, estimated; dup, duplicate; - -, not applicable or not available]

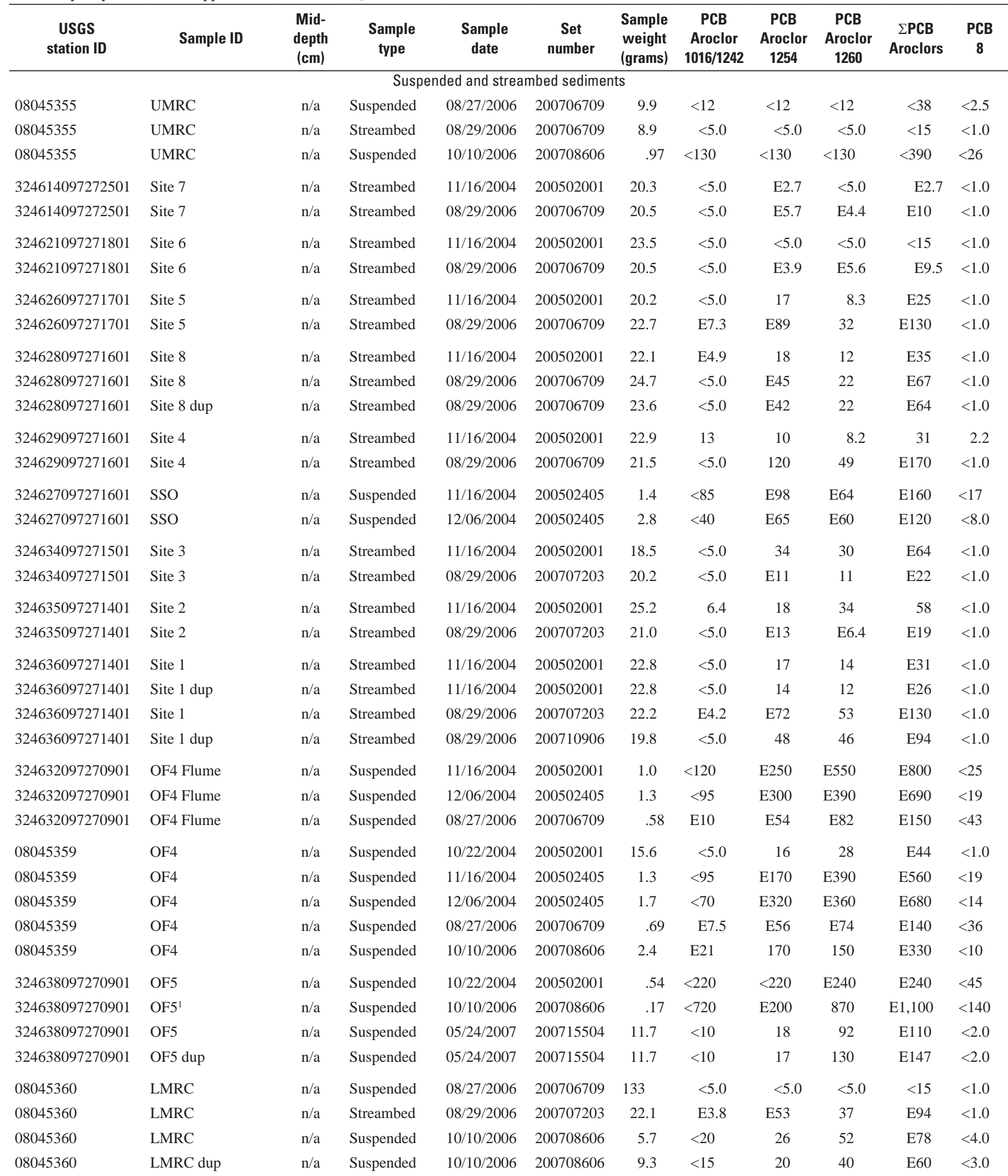

Footnotes at end of table. 
Appendix 2. Polychlorinated biphenyl (PCB) Aroclor and congener, organic carbon, and organochlorine pesticide concentrations in suspended, streambed, and lake-bottom sediment samples from sites in and near Meandering Road Creek and Woods Inlet of Lake Worth, Fort Worth, Texas, 2004 and 2006-07-Continued.

\begin{tabular}{|c|c|c|c|c|c|c|c|c|c|c|c|}
\hline $\begin{array}{c}\text { USGS } \\
\text { station ID }\end{array}$ & Sample ID & $\begin{array}{c}\text { Mid- } \\
\text { depth } \\
\text { (cm) }\end{array}$ & $\begin{array}{c}\text { Sample } \\
\text { type }\end{array}$ & $\begin{array}{l}\text { Sample } \\
\text { date }\end{array}$ & $\begin{array}{c}\text { Set } \\
\text { number }\end{array}$ & $\begin{array}{l}\text { Sample } \\
\text { weight } \\
\text { (grams) }\end{array}$ & $\begin{array}{c}\text { PCB } \\
\text { Aroclor } \\
1016 / 1242\end{array}$ & $\begin{array}{c}\text { PCB } \\
\text { Aroclor } \\
1254\end{array}$ & $\begin{array}{c}\text { PCB } \\
\text { Aroclor } \\
1260\end{array}$ & $\begin{array}{c}\Sigma \mathrm{PCB} \\
\text { Aroclors }\end{array}$ & $\begin{array}{c}\text { PCB } \\
8\end{array}$ \\
\hline \multicolumn{12}{|c|}{ Lake bottom sediments } \\
\hline 324643097271501 & WWD.B6 0-1 & 0.5 & Lake bottom & $08 / 28 / 2006$ & 200636101 & 20.6 & E3.8 & 33 & 32 & E69 & $<1.0$ \\
\hline 324646097271601 & WWD.B7 0-1 & .5 & Lake bottom & $08 / 28 / 2006$ & 200703201 & 16.6 & 34 & E250 & 170 & $\mathrm{E} 450$ & E. 8 \\
\hline 324649097271601 & WWD.3 1-3 & 2.0 & Lake bottom & $08 / 28 / 2006$ & 200703606 & 17.4 & E5.9 & E44 & 28 & E78 & $<1.0$ \\
\hline 324649097271601 & WWD.3 3-5 & 4.0 & Lake bottom & $08 / 28 / 2006$ & 200703606 & 18.4 & $<5.0$ & E45 & 31 & E76 & $<1.0$ \\
\hline 324649097271601 & WWD. 3 5-10 & 7.5 & Lake bottom & $08 / 28 / 2006$ & 200703606 & 19.6 & 7.1 & $\mathrm{E} 43$ & 28 & E78 & $<1.0$ \\
\hline 324649097271601 & WWD.3 10-13 & 11.5 & Lake bottom & $08 / 28 / 2006$ & 200703606 & 17.4 & 9.3 & E63 & 38 & E110 & $<1.0$ \\
\hline 324649097271601 & WWD.3 10-13 dup & 11.5 & Lake bottom & $08 / 28 / 2006$ & 200703606 & 17.4 & 7.7 & E49 & 32 & E88 & $<1.0$ \\
\hline 324647097272101 & WWD.B4 0-2 & 1.0 & Lake bottom & $08 / 28 / 2006$ & 200636101 & 12.2 & $<10$ & 12 & 14 & E26 & $<2.0$ \\
\hline 324647097272101 & WWD.B4 0-2 dup & 1.0 & Lake bottom & $08 / 28 / 2006$ & 200636101 & 12.7 & $<10$ & 12 & 13 & E25 & $<2.0$ \\
\hline 324649097271901 & WWD.B5 0-1 & .5 & Lake bottom & $08 / 28 / 2006$ & 200703201 & 22.5 & $<5.0$ & E6.3 & 7.0 & E13 & $<1.0$ \\
\hline 324649097271901 & WWD.B5 0-1 dup & .5 & Lake bottom & $08 / 28 / 2006$ & 200703201 & 22.4 & $<5.0$ & E6.8 & E4.4 & E11 & $<1.0$ \\
\hline \multicolumn{12}{|l|}{ Gruggs arm } \\
\hline 324658097273301 & WWD.B1 0-1.5 & .75 & Lake bottom & $08 / 28 / 2006$ & 200703201 & 16.6 & $<5.0$ & E6.9 & 13 & E20 & $<1.0$ \\
\hline 324658097273001 & WWD.B2 0-1 & .5 & Lake bottom & $08 / 28 / 2006$ & 200636101 & 19.3 & $<5.0$ & E6.7 & E12 & E18 & $<1.0$ \\
\hline 324656097272301 & WWD.B3 0-1 & .5 & Lake bottom & $08 / 28 / 2006$ & 200636101 & 11.6 & $<10$ & 10 & 13 & E24 & $<2.0$ \\
\hline 324658097272501 & WWD.2 0-1 & .5 & Lake bottom & $08 / 28 / 2006$ & 200703606 & 16.1 & $<5.0$ & E8.0 & 13 & E21 & $<1.0$ \\
\hline 324658097272501 & WWD.2 0-1 dup & .5 & Lake bottom & $08 / 28 / 2006$ & 200703606 & 16.2 & $<5.0$ & E15 & 15 & E30 & $<1.0$ \\
\hline 324657097271901 & WWD.1 3-5 & 4.0 & Lake bottom & $08 / 28 / 2006$ & 200703201 & 14.6 & E4.2 & E23 & 19 & E46 & $<1.0$ \\
\hline 324657097271901 & WWD.1 5-10 & 7.5 & Lake bottom & $08 / 28 / 2006$ & 200703201 & 13.3 & E4.6 & E22 & 19 & E46 & $<2.0$ \\
\hline 324657097271901 & WWD.1 10-15 & 12.5 & Lake bottom & $08 / 28 / 2006$ & 200703201 & 13.7 & E6.2 & E28 & 21 & E56 & $<2.0$ \\
\hline 324659097271601 & WWD.B10 0-1 & .5 & Lake bottom & $08 / 28 / 2006$ & 200703201 & 12.8 & $<10$ & E18 & 13 & E31 & $<2.0$ \\
\hline 324800097271701 & WWD.B11 0-1 & .5 & Lake bottom & $08 / 28 / 2006$ & 200636101 & 11.1 & $<10$ & 12 & 16 & E27 & $<2.0$ \\
\hline 324700097271901 & WWD.B12 0-1 & .5 & Lake bottom & $08 / 28 / 2006$ & 200703201 & 12.6 & E5.0 & E25 & 23 & E53 & $<2.0$ \\
\hline \multicolumn{12}{|l|}{ Upper Woods Inlet } \\
\hline 324703097271401 & WWD.B13 0-1 & .5 & Lake bottom & $08 / 28 / 2006$ & 200634208 & 10.8 & $<10$ & E8.0 & E5.9 & E14 & $<2.0$ \\
\hline 324704097271601 & WWD.B14 0-2 & 1.0 & Lake bottom & $08 / 28 / 2006$ & 200636101 & 12.0 & $<10$ & 12 & 9.8 & E22 & $<2.0$ \\
\hline 324705097271701 & WWD.B15 0-2 & 1.0 & Lake bottom & $08 / 28 / 2006$ & 200636101 & 21.7 & $<5.0$ & $<5.0$ & $<5.0$ & $<15$ & $<1.0$ \\
\hline 324703097270901 & WWD.B16 0-1 & .5 & Lake bottom & $08 / 28 / 2006$ & 200636101 & 11.2 & $<10$ & E9.9 & 10 & E20 & $<2.0$ \\
\hline 324709097271201 & WWD.B17 0-2 & 1.0 & Lake bottom & $08 / 28 / 2006$ & 200703201 & 10.7 & $<10$ & E7.5 & E6.5 & E14 & $<2.0$ \\
\hline \multicolumn{12}{|c|}{ Sediment quality guidelines } \\
\hline \multicolumn{2}{|c|}{ Threshold effect concentration (TEC) $)^{2}$} & -- & -- & - & - & - & - & - & - & 59.8 & - \\
\hline \multicolumn{2}{|c|}{ Probable effect concentration $(\mathrm{PEC})^{2}$} & - & - & - & - & - & - & - & - & 676.0 & - \\
\hline
\end{tabular}

Footnotes at end of table. 
Appendix 2. Polychlorinated biphenyl (PCB) Aroclor and congener, organic carbon, and organochlorine pesticide concentrations in suspended, streambed, and lake-bottom sediment samples from sites in and near Meandering Road Creek and Woods Inlet of Lake Worth, Fort Worth, Texas, 2004 and 2006-07-Continued.

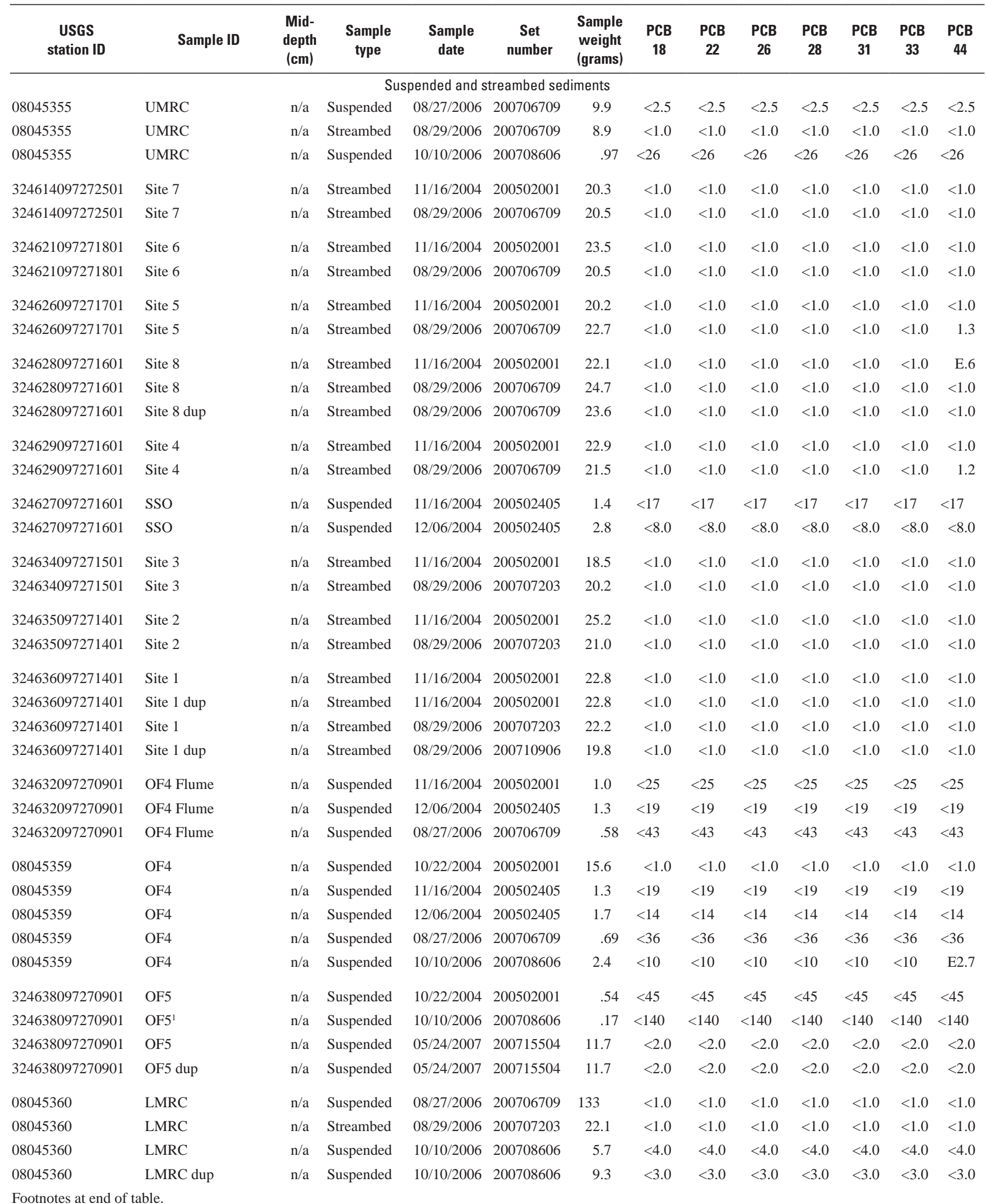


Appendix 2. Polychlorinated biphenyl (PCB) Aroclor and congener, organic carbon, and organochlorine pesticide concentrations in suspended, streambed, and lake-bottom sediment samples from sites in and near Meandering Road Creek and Woods Inlet of Lake Worth, Fort Worth, Texas, 2004 and 2006-07-Continued.

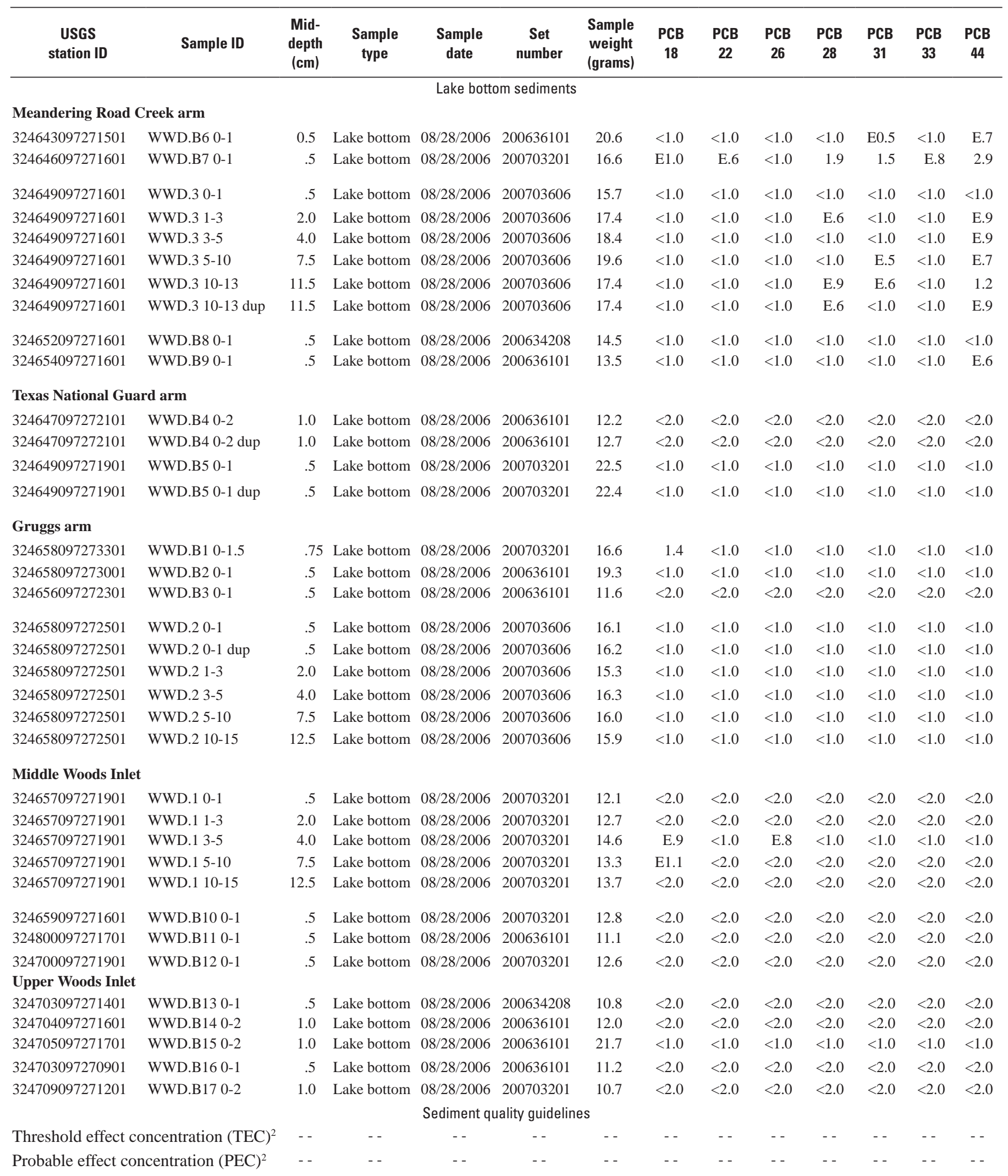

Footnotes at end of table. 
Appendix 2. Polychlorinated biphenyl (PCB) Aroclor and congener, organic carbon, and organochlorine pesticide concentrations in suspended, streambed, and lake-bottom sediment samples from sites in and near Meandering Road Creek and Woods Inlet of Lake Worth, Fort Worth, Texas, 2004 and 2006-07-Continued.

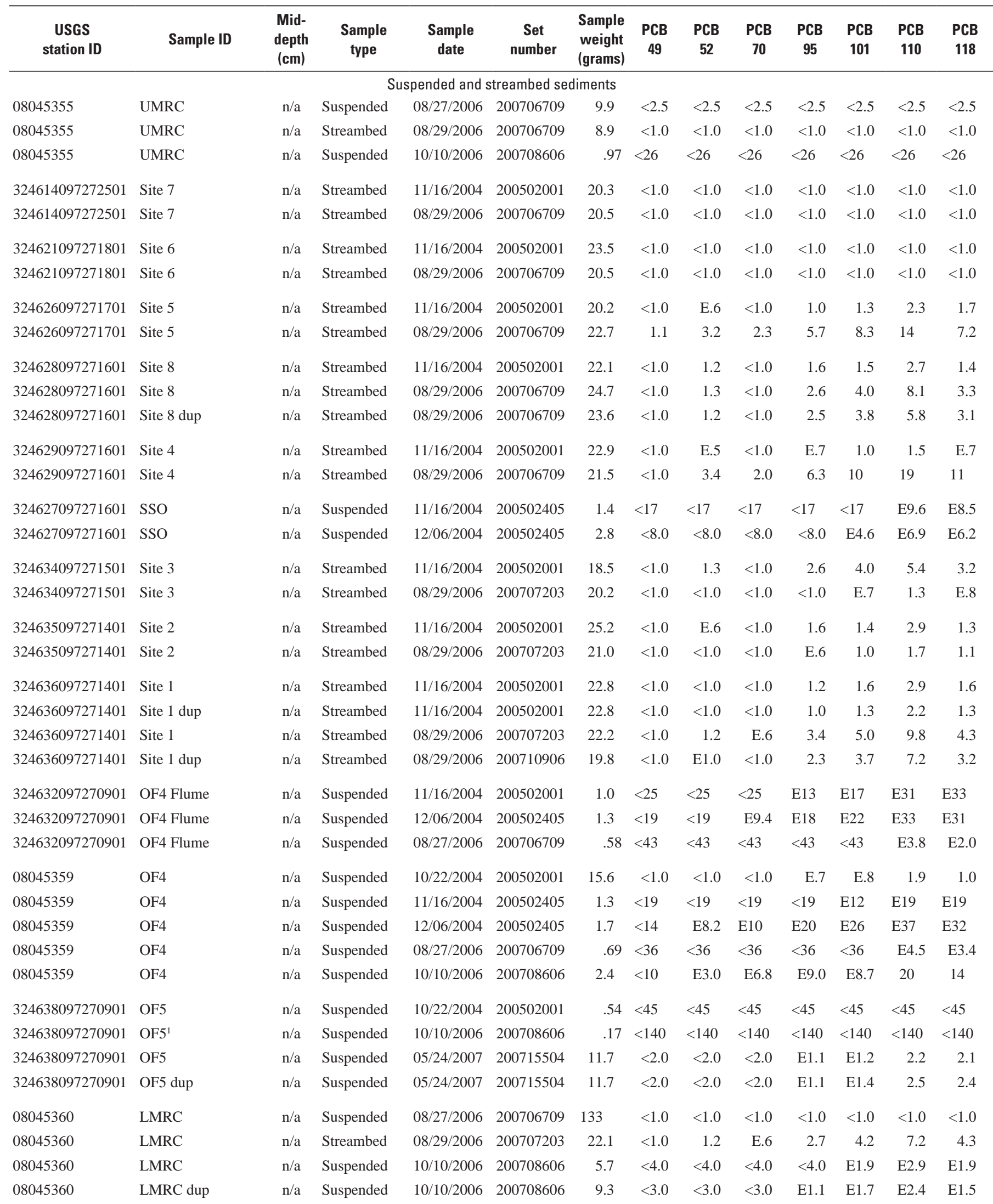

Footnotes at end of table. 
Appendix 2. Polychlorinated biphenyl (PCB) Aroclor and congener, organic carbon, and organochlorine pesticide concentrations in suspended, streambed, and lake-bottom sediment samples from sites in and near Meandering Road Creek and Woods Inlet of Lake Worth, Fort Worth, Texas, 2004 and 2006-07-Continued.

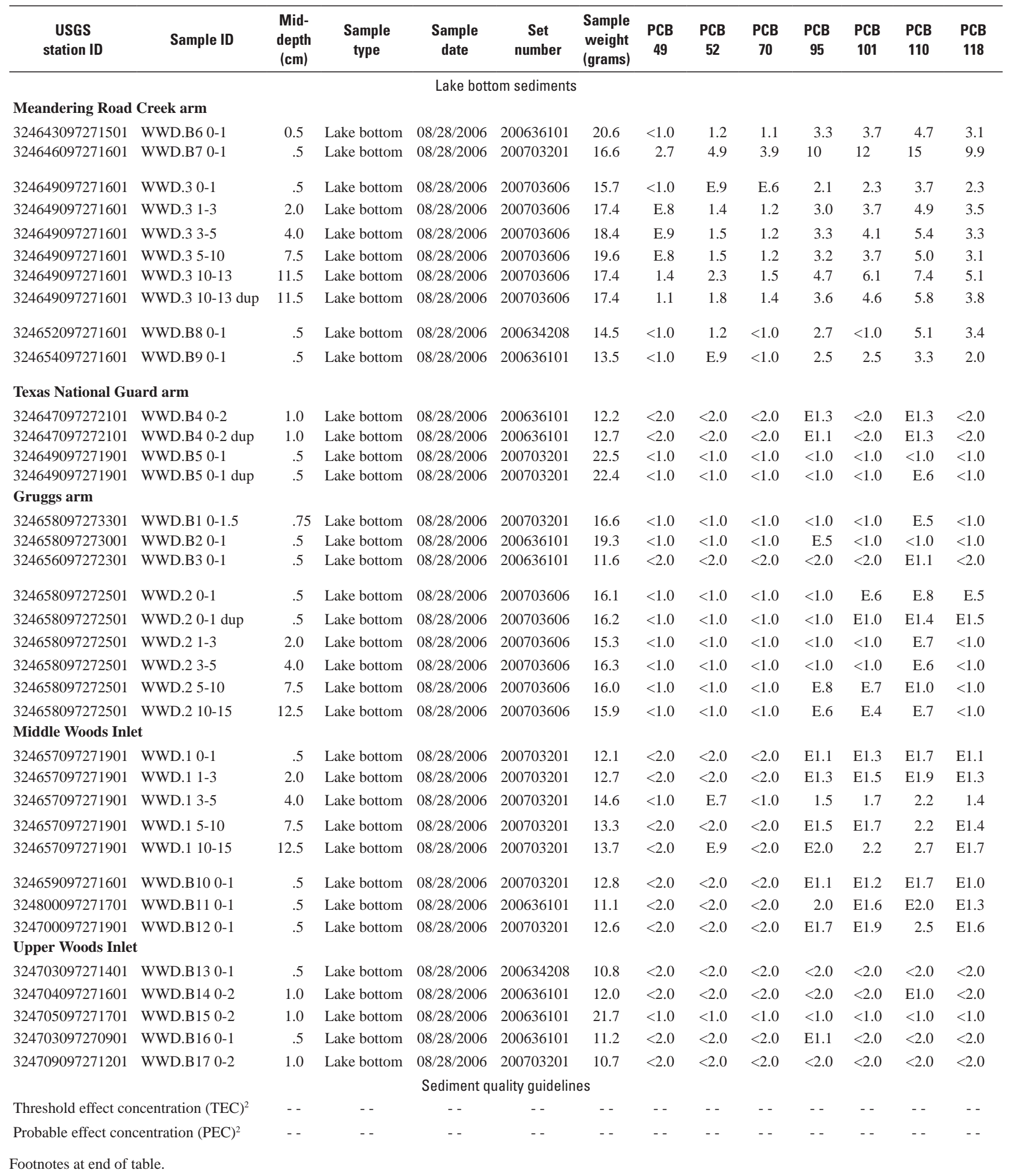


Appendix 2. Polychlorinated biphenyl (PCB) Aroclor and congener, organic carbon, and organochlorine pesticide concentrations in suspended, streambed, and lake-bottom sediment samples from sites in and near Meandering Road Creek and Woods Inlet of Lake Worth, Fort Worth, Texas, 2004 and 2006-07-Continued.

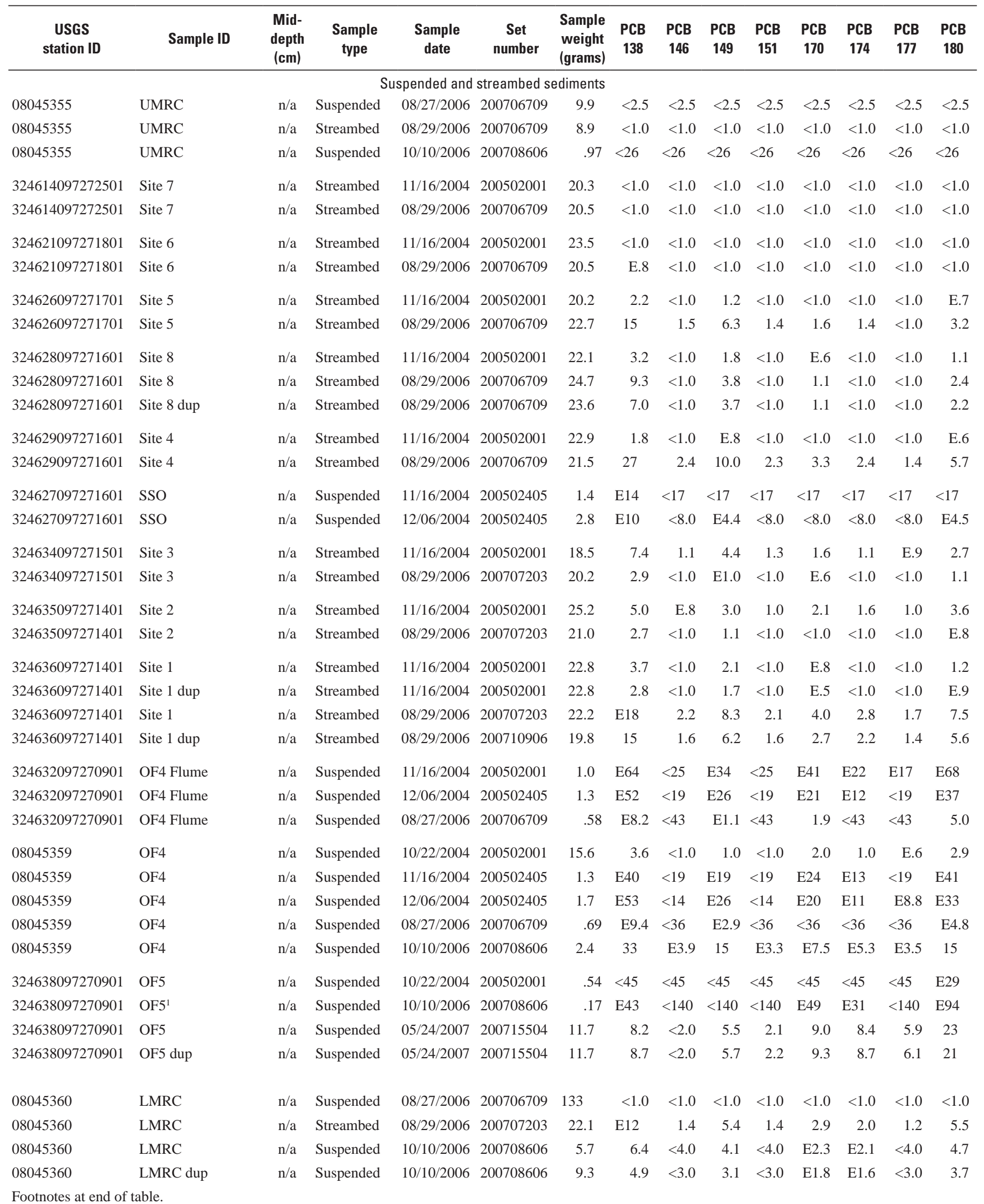


Appendix 2. Polychlorinated biphenyl (PCB) Aroclor and congener, organic carbon, and organochlorine pesticide concentrations in suspended, streambed, and lake-bottom sediment samples from sites in and near Meandering Road Creek and Woods Inlet of Lake Worth, Fort Worth, Texas, 2004 and 2006-07-Continued.

\begin{tabular}{|c|c|c|c|c|c|c|c|c|c|c|c|c|c|c|}
\hline $\begin{array}{c}\text { USGS } \\
\text { station ID }\end{array}$ & Sample ID & $\begin{array}{c}\text { Mid- } \\
\text { depth } \\
\text { (cm) }\end{array}$ & $\begin{array}{c}\text { Sample } \\
\text { type }\end{array}$ & $\begin{array}{c}\text { Sample } \\
\text { date }\end{array}$ & $\begin{array}{c}\text { Set } \\
\text { number }\end{array}$ & $\begin{array}{c}\text { Sample } \\
\text { weight } \\
\text { (grams) }\end{array}$ & $\begin{array}{c}\text { PCB } \\
138\end{array}$ & $\begin{array}{l}\text { PCB } \\
146\end{array}$ & $\begin{array}{l}\text { РCB } \\
149\end{array}$ & $\begin{array}{c}\text { PCB } \\
151\end{array}$ & $\begin{array}{l}\text { РCB } \\
170\end{array}$ & $\begin{array}{c}\text { PCB } \\
174\end{array}$ & $\begin{array}{c}\text { PCB } \\
177\end{array}$ & $\begin{array}{l}\text { PCB } \\
180\end{array}$ \\
\hline \multicolumn{15}{|c|}{ Lake bottom sediments } \\
\hline 324643097271501 & WWD.B6 0-1 & 0.5 & Lake bottom & $08 / 28 / 2006$ & 200636101 & 20.6 & 7.9 & E1.0 & 3.9 & 1.3 & 1.7 & 1.2 & E. 8 & 3.3 \\
\hline 324646097271601 & WWD.B7 0-1 & .5 & Lake bottom & $08 / 28 / 2006$ & 200703201 & 16.6 & 19 & 2.6 & 12 & 3.0 & 4.4 & 3.7 & 2.3 & 9.1 \\
\hline 324649097271601 & WWD.3 1-3 & 2.0 & Lake bottom & $08 / 28 / 2006$ & 200703606 & 17.4 & 6.3 & E. 8 & 3.5 & E. 9 & 1.4 & 1.2 & E.7 & 2.8 \\
\hline 324649097271601 & WWD.3 3-5 & 4.0 & Lake bottom & $08 / 28 / 2006$ & 200703606 & 18.4 & 7.0 & E.7 & 4.0 & 1.0 & 1.5 & 1.2 & E. 8 & 2.9 \\
\hline 324649097271601 & WWD.3 5-10 & 7.5 & Lake bottom & $08 / 28 / 2006$ & 200703606 & 19.6 & 6.1 & E.6 & $<1.0$ & E.9 & 1.4 & 1.2 & E.7 & E2.8 \\
\hline 324649097271601 & WWD.3 10-13 & 11.5 & Lake bottom & $08 / 28 / 2006$ & 200703606 & 17.4 & 8.1 & 1.2 & 4.8 & 1.2 & 2.0 & 1.5 & E1.0 & 3.8 \\
\hline 324649097271601 & WWD.3 10-13 dup & 11.5 & Lake bottom & $08 / 28 / 2006$ & 200703606 & 17.4 & 7.5 & E1.0 & 4.5 & 1.2 & 1.6 & 1.4 & E. 8 & 3.1 \\
\hline 324647097272101 & WWD.B4 0-2 & 1.0 & Lake bottom & $08 / 28 / 2006$ & 200636101 & 12.2 & E1.3 & $<2.0$ & E1.2 & $<2.0$ & $<2.0$ & $<2.0$ & $<2.0$ & E1.3 \\
\hline 324647097272101 & WWD.B4 0-2 dup & 1.0 & Lake bottom & $08 / 28 / 2006$ & 200636101 & 12.7 & E1.0 & $<2.0$ & E1.2 & $<2.0$ & $<2.0$ & $<2.0$ & $<2.0$ & E1.4 \\
\hline 324649097271901 & WWD.B5 0-1 & .5 & Lake bottom & $08 / 28 / 2006$ & 200703201 & 22.5 & $<1.0$ & $<1.0$ & $<1.0$ & $<1.0$ & $<1.0$ & $<1.0$ & $<1.0$ & E.5 \\
\hline 324649097271901 & WWD.B5 0-1 dup & .5 & Lake bottom & $08 / 28 / 2006$ & 200703201 & 22.4 & E.7 & $<1.0$ & $<1.0$ & $<1.0$ & $<1.0$ & $<1.0$ & $<1.0$ & $<1.0$ \\
\hline \multicolumn{15}{|l|}{ Gruggs arm } \\
\hline 324658097273301 & WWD.B1 0-1.5 & .75 & Lake bottom & $08 / 28 / 2006$ & 200703201 & 16.6 & 1.4 & $<1.0$ & 1.0 & $<1.0$ & E.6 & E.5 & $<1.0$ & 1.3 \\
\hline 324658097273001 & WWD.B2 0-1 & .5 & Lake bottom & $08 / 28 / 2006$ & 200636101 & 19.3 & E1.2 & $<1.0$ & E.6 & $<1.0$ & $<1.0$ & $<1.0$ & $<1.0$ & E1.2 \\
\hline 324656097272301 & WWD.B3 0-1 & .5 & Lake bottom & $08 / 28 / 2006$ & 200636101 & 11.6 & E1.5 & $<2.0$ & E1.1 & $<2.0$ & $<2.0$ & $<2.0$ & $<2.0$ & E1.2 \\
\hline 324658097272501 & WWD.2 0-1 & .5 & Lake bottom & $08 / 28 / 2006$ & 200703606 & 16.1 & 1.3 & $<1.0$ & E.9 & $<1.0$ & $<1.0$ & $<1.0$ & $<1.0$ & $<1.0$ \\
\hline 324657097271901 & WWD.1 3-5 & 4.0 & Lake bottom & $08 / 28 / 2006$ & 200703201 & 14.6 & 2.8 & $<1.0$ & 1.8 & $<1.0$ & E.7 & E.6 & $<1.0$ & 1.6 \\
\hline 324657097271901 & WWD.1 5-10 & 7.5 & Lake bottom & $08 / 28 / 2006$ & 200703201 & 13.3 & 2.7 & $<2.0$ & E1.8 & $<2.0$ & $<2.0$ & $<2.0$ & $<2.0$ & E1.5 \\
\hline 324657097271901 & WWD.1 10-15 & 12.5 & Lake bottom & $08 / 28 / 2006$ & 200703201 & 13.7 & 3.2 & $<2.0$ & 2.1 & $<2.0$ & $<2.0$ & $<2.0$ & $<2.0$ & E1.7 \\
\hline 324659097271601 & WWD.B10 0-1 & .5 & Lake bottom & $08 / 28 / 2006$ & 200703201 & 12.8 & 2.1 & $<2.0$ & E1.3 & $<2.0$ & $<2.0$ & $<2.0$ & $<2.0$ & $<2.0$ \\
\hline 324800097271701 & WWD.B11 0-1 & .5 & Lake bottom & $08 / 28 / 2006$ & 200636101 & 11 & 2.6 & $<2.0$ & E1.5 & $<2.0$ & $<2.0$ & $<2.0$ & $<2.0$ & E1.4 \\
\hline 324700097271901 & WWD.B12 0-1 & .5 & Lake bottom & $08 / 28 / 2006$ & 200703201 & 12.6 & 3.1 & $<2.0$ & 2.1 & $<2.0$ & $<2.0$ & $<2.0$ & $<2.0$ & E1.9 \\
\hline \multicolumn{15}{|l|}{ Upper Woods Inlet } \\
\hline 324703097271401 & WWD.B13 0-1 & .5 & Lake bottom & $08 / 28 / 2006$ & 200634208 & 10.8 & $<2.0$ & $<2.0$ & $<2.0$ & $<2.0$ & $<2.0$ & $<2.0$ & $<2.0$ & $<2.0$ \\
\hline 324704097271601 & WWD.B14 0-2 & 1.0 & Lake bottom & $08 / 28 / 2006$ & 200636101 & 12.0 & E1.5 & $<2.0$ & $<2.0$ & $<2.0$ & $<2.0$ & $<2.0$ & $<2.0$ & $<2.0$ \\
\hline 324705097271701 & WWD.B15 0-2 & 1.0 & Lake bottom & $08 / 28 / 2006$ & 200636101 & 21.7 & $<1.0$ & $<1.0$ & $<1.0$ & $<1.0$ & $<1.0$ & $<1.0$ & $<1.0$ & $<1.0$ \\
\hline 324703097270901 & WWD.B16 0-1 & .5 & Lake bottom & $08 / 28 / 2006$ & 200636101 & 11.2 & E1.3 & $<2.0$ & $<2.0$ & $<2.0$ & $<2.0$ & $<2.0$ & $<2.0$ & $<2.0$ \\
\hline 324709097271201 & WWD.B17 0-2 & 1.0 & Lake bottom & $08 / 28 / 2006$ & 200703201 & 10.7 & $<2.0$ & $<2.0$ & $<2.0$ & $<2.0$ & $<2.0$ & $<2.0$ & $<2.0$ & $<2.0$ \\
\hline \multicolumn{15}{|c|}{ Sediment quality guidelines } \\
\hline Threshold effect co & ncentration $(\mathrm{TEC})^{2}$ & -- & -- & -- & -- & -- & -- & -- & - & -- & -- & - & -- & -- \\
\hline Probable effect con & centration $(\mathrm{PEC})^{2}$ & - & -- & -- & - & - & - & - & - & - & - & - & - & - \\
\hline
\end{tabular}

Footnotes at end of table. 
Appendix 2. Polychlorinated biphenyl (PCB) Aroclor and congener, organic carbon, and organochlorine pesticide concentrations in suspended, streambed, and lake-bottom sediment samples from sites in and near Meandering Road Creek and Woods Inlet of Lake Worth, Fort Worth, Texas, 2004 and 2006-07-Continued.

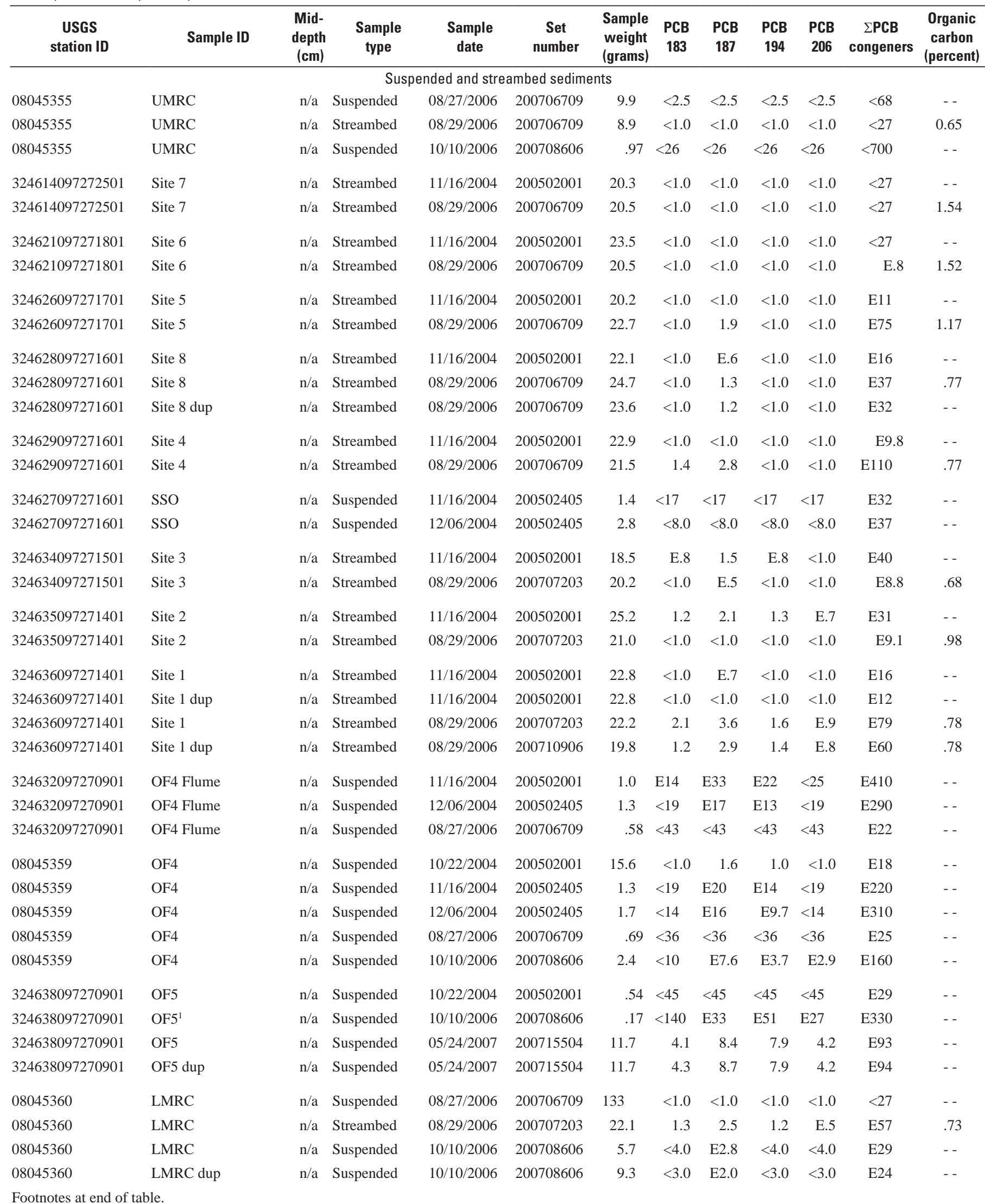


Appendix 2. Polychlorinated biphenyl (PCB) Aroclor and congener, organic carbon, and organochlorine pesticide concentrations in suspended, streambed, and lake-bottom sediment samples from sites in and near Meandering Road Creek and Woods Inlet of Lake Worth, Fort Worth, Texas, 2004 and 2006-07-Continued.

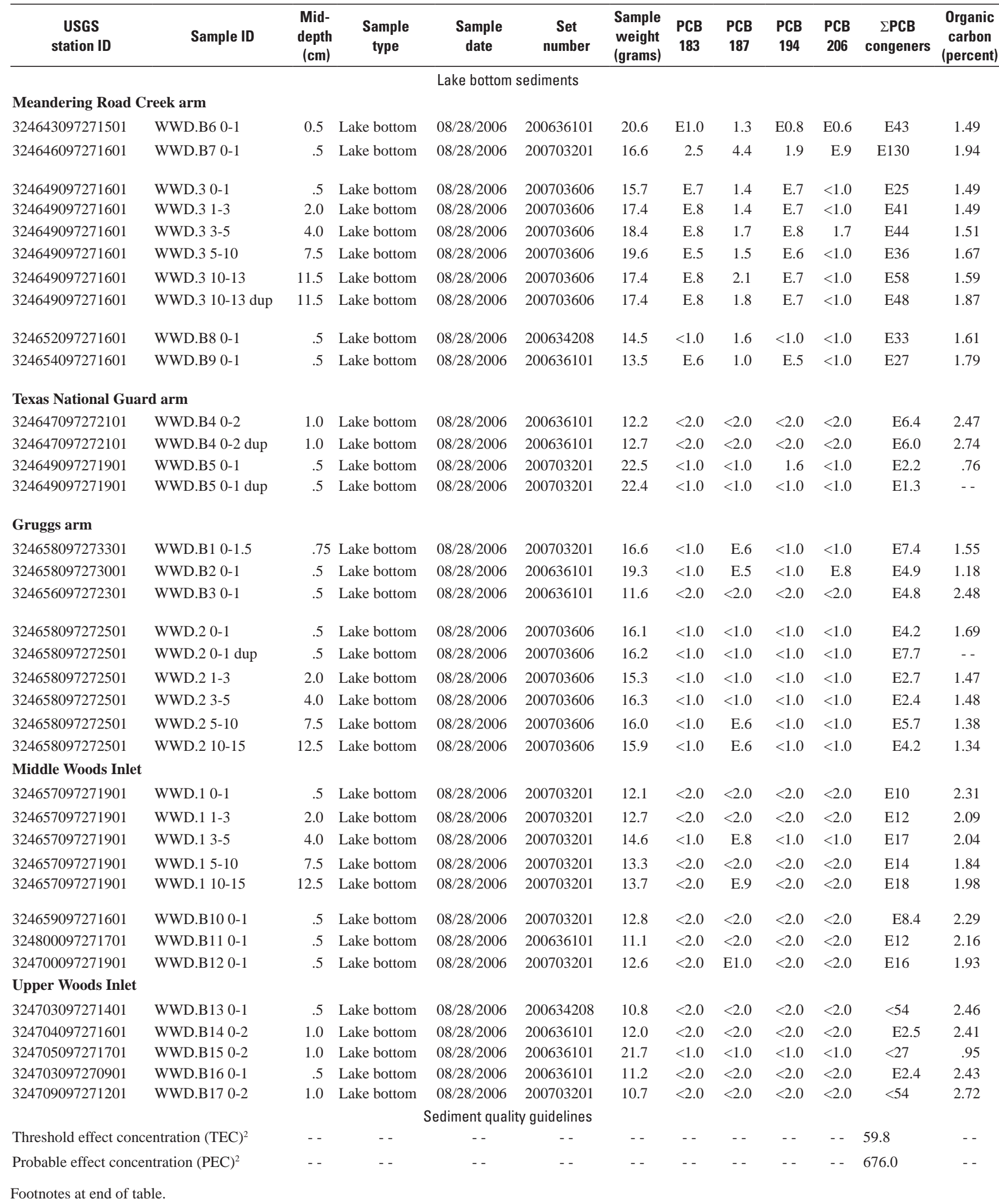


Appendix 2. Polychlorinated biphenyl (PCB) Aroclor and congener, organic carbon, and organochlorine pesticide concentrations in suspended, streambed, and lake-bottom sediment samples from sites in and near Meandering Road Creek and Woods Inlet of Lake Worth, Fort Worth, Texas, 2004 and 2006-07-Continued.

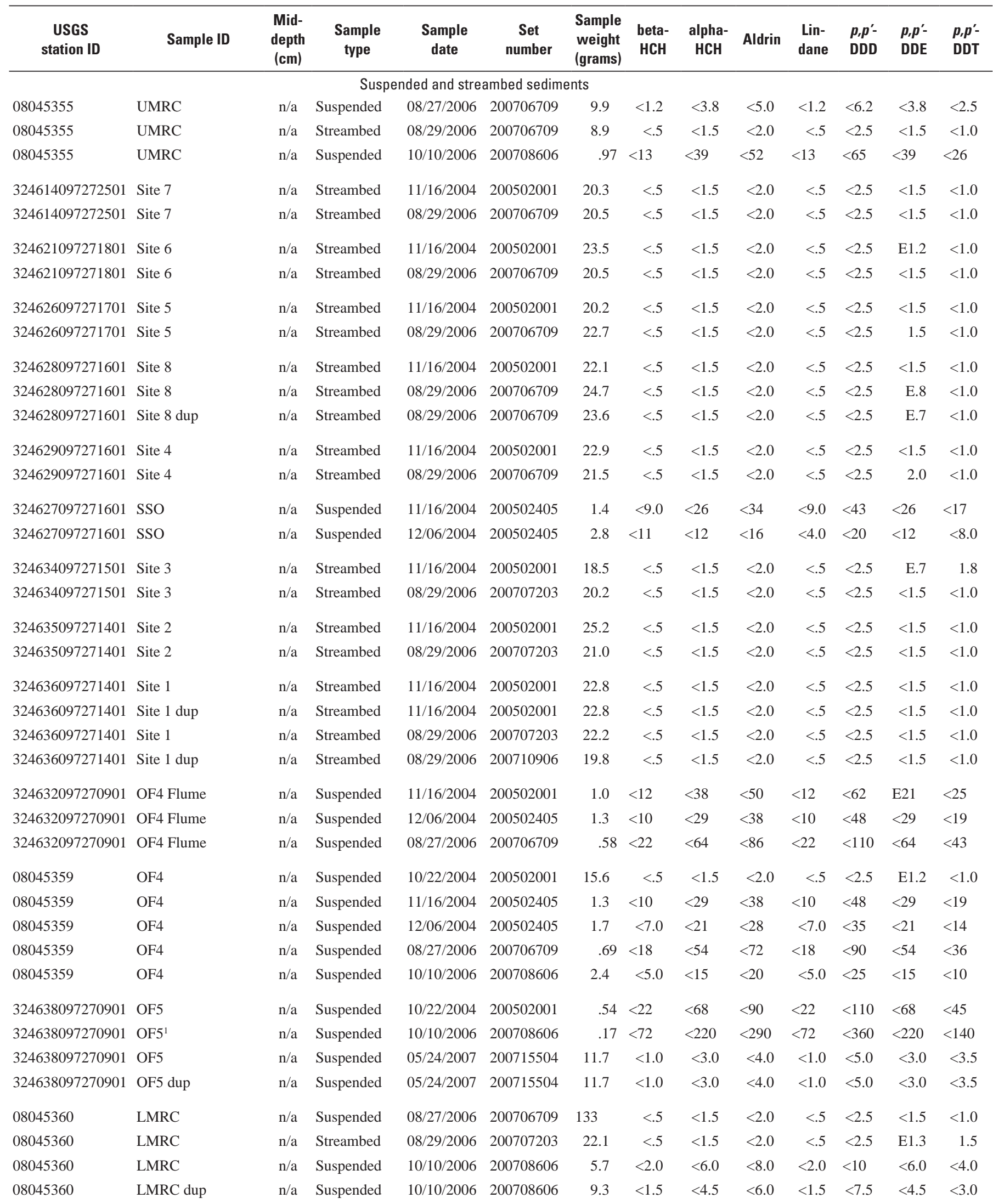

Footnotes at end of table. 
Appendix 2. Polychlorinated biphenyl (PCB) Aroclor and congener, organic carbon, and organochlorine pesticide concentrations in suspended, streambed, and lake-bottom sediment samples from sites in and near Meandering Road Creek and Woods Inlet of Lake Worth, Fort Worth, Texas, 2004 and 2006-07-Continued.

\begin{tabular}{|c|c|c|c|c|c|c|c|c|c|c|c|c|c|}
\hline $\begin{array}{c}\text { USGS } \\
\text { station ID }\end{array}$ & Sample ID & $\begin{array}{l}\text { Mid- } \\
\text { depth } \\
\text { (cm) }\end{array}$ & $\begin{array}{c}\text { Sample } \\
\text { type }\end{array}$ & $\begin{array}{l}\text { Sample } \\
\text { date }\end{array}$ & $\begin{array}{c}\text { Set } \\
\text { number }\end{array}$ & $\begin{array}{l}\text { Sample } \\
\text { weight } \\
\text { (grams) }\end{array}$ & $\begin{array}{l}\text { beta- } \\
\text { HCH }\end{array}$ & $\begin{array}{l}\text { alpha- } \\
\text { HCH }\end{array}$ & Aldrin & $\begin{array}{l}\text { Lin- } \\
\text { dane }\end{array}$ & $\begin{array}{l}p, p^{\prime}- \\
\text { DDD }\end{array}$ & $\begin{array}{l}p, p^{\prime}- \\
\text { DDE }\end{array}$ & $\begin{array}{l}p, p^{\prime}- \\
\text { DDT }\end{array}$ \\
\hline \multicolumn{14}{|c|}{ Lake bottom sediments } \\
\hline 324643097271501 & WWD.B6 0-1 & 0.5 & Lake bottom & $08 / 28 / 2006$ & 200636101 & 20.6 & $<0.5$ & $<1.5$ & $<2.0$ & $<0.5$ & $<2.5$ & $<1.5$ & $<1.0$ \\
\hline 324646097271601 & WWD.B7 0-1 & .5 & Lake bottom & $08 / 28 / 2006$ & 200703201 & 16.6 & $<.5$ & $<1.5$ & $<2.0$ & $<.5$ & $\mathrm{E} 2.1$ & 1.8 & $<1.0$ \\
\hline 324649097271601 & WWD.3 3-5 & 4.0 & Lake bottom & $08 / 28 / 2006$ & 200703606 & 18.4 & $<.5$ & $<1.5$ & $<2.0$ & $<.5$ & $<2.5$ & $<1.5$ & $<1.0$ \\
\hline 324649097271601 & WWD.3 5-10 & 7.5 & Lake bottom & $08 / 28 / 2006$ & 200703606 & 19.6 & $<.5$ & $<1.5$ & $<2.0$ & $<.5$ & $<2.5$ & $<1.5$ & $<1.0$ \\
\hline 324649097271601 & WWD.3 10-13 & 11.5 & Lake bottom & $08 / 28 / 2006$ & 200703606 & 17.4 & $<.5$ & $<1.5$ & $<2.0$ & $<.5$ & $<2.5$ & $<1.5$ & $<1.0$ \\
\hline 324649097271601 & WWD.3 10-13 dup & 11.5 & Lake bottom & $08 / 28 / 2006$ & 200703606 & 17.4 & $<.5$ & $<1.5$ & $<2.0$ & $<.5$ & $<2.5$ & $<1.5$ & $<1.0$ \\
\hline 324647097272101 & WWD.B4 0-2 dup & 1.0 & Lake bottom & $08 / 28 / 2006$ & 200636101 & 12.7 & $<1.0$ & $<3.0$ & $<4.0$ & $<1.0$ & $<5.0$ & $<3.0$ & $<2.0$ \\
\hline 324649097271901 & WWD.B5 0-1 & .5 & Lake bottom & $08 / 28 / 2006$ & 200703201 & 22.5 & $<.5$ & $<1.5$ & $<2.0$ & $<.5$ & $<2.5$ & $<1.5$ & $<1.0$ \\
\hline 324649097271901 & WWD.B5 0-1 dup & .5 & Lake bottom & $08 / 28 / 2006$ & 200703201 & 22.4 & $<.5$ & $<1.5$ & $<2.0$ & $<.5$ & $<2.5$ & E1.1 & $<1.0$ \\
\hline \multicolumn{14}{|l|}{ Gruggs arm } \\
\hline 324658097273301 & WWD.B1 0-1.5 & .75 & Lake bottom & $08 / 28 / 2006$ & 200703201 & 16.6 & $<.5$ & $<1.5$ & $<2.0$ & $<.5$ & $<2.5$ & E1.1 & $<1.0$ \\
\hline 324658097273001 & WWD.B2 0-1 & .5 & Lake bottom & $08 / 28 / 2006$ & 200636101 & 19.3 & $<.5$ & $<1.5$ & $<2.0$ & $<.5$ & $<2.5$ & $<1.5$ & $<1.0$ \\
\hline 324656097272301 & WWD.B3 0-1 & .5 & Lake bottom & $08 / 28 / 2006$ & 200636101 & 11.6 & $<1.0$ & $<3.0$ & $<4.0$ & $<1.0$ & $<5.0$ & $<3.0$ & $<2.0$ \\
\hline 324658097272501 & WWD.2 0-1 & .5 & Lake bottom & $08 / 28 / 2006$ & 200703606 & 16.1 & $<.5$ & $<1.5$ & $<2.0$ & $<.5$ & $<2.5$ & E. 8 & $<1.0$ \\
\hline 324658097272501 & WWD.2 0-1 dup & .5 & Lake bottom & $08 / 28 / 2006$ & 200703606 & 16.2 & $<.5$ & $<1.5$ & $<2.0$ & $<.5$ & $<2.5$ & E.9 & $<1.0$ \\
\hline \multicolumn{14}{|l|}{ M iddle Woods Inlet } \\
\hline 324657097271901 & WWD.1 3-5 & 4.0 & Lake bottom & $08 / 28 / 2006$ & 200703201 & 14.6 & E. 3 & $<1.5$ & $<2.0$ & $<.5$ & $<2.5$ & E.9 & $<1.0$ \\
\hline 324657097271901 & WWD.1 5-10 & 7.5 & Lake bottom & $08 / 28 / 2006$ & 200703201 & 13.3 & $<1.0$ & $<3.0$ & $<4.0$ & $<1.0$ & $<5.0$ & $<3.0$ & $<2.0$ \\
\hline 324657097271901 & WWD.1 10-15 & 12.5 & Lake bottom & $08 / 28 / 2006$ & 200703201 & 13.7 & $<1.0$ & $<3.0$ & $<4.0$ & $<1.0$ & $<5.0$ & $<3.0$ & $<2.0$ \\
\hline 324659097271601 & WWD.B10 0-1 & .5 & Lake bottom & $08 / 28 / 2006$ & 200703201 & 12.8 & $<1.0$ & $<3.0$ & $<4.0$ & $<1.0$ & $<5.0$ & $<3.0$ & $<2.0$ \\
\hline 324800097271701 & WWD.B11 0-1 & .5 & Lake bottom & $08 / 28 / 2006$ & 200636101 & 11.1 & $<1.0$ & $<3.0$ & $<4.0$ & $<1.0$ & $<5.0$ & $<3.0$ & $<2.0$ \\
\hline 324700097271901 & WWD.B12 0-1 & .5 & Lake bottom & $08 / 28 / 2006$ & 200703201 & 12.6 & $<1.0$ & $<3.0$ & $<4.0$ & $<1.0$ & $<5.0$ & $<3.0$ & $<2.0$ \\
\hline \multicolumn{14}{|l|}{ Upper Woods Inlet } \\
\hline 324703097271401 & WWD.B13 0-1 & .5 & Lake bottom & $08 / 28 / 2006$ & 200634208 & 10.8 & $<1.0$ & $<3.0$ & $<4.0$ & $<1.0$ & $<5.0$ & $<3.0$ & $<2.0$ \\
\hline 324704097271601 & WWD.B14 0-2 & 1.0 & Lake bottom & $08 / 28 / 2006$ & 200636101 & 12.0 & $<1.0$ & $<3.0$ & $<4.0$ & $<1.0$ & $<5.0$ & $<3.0$ & $<2.0$ \\
\hline 324705097271701 & WWD.B15 0-2 & 1.0 & Lake bottom & $08 / 28 / 2006$ & 200636101 & 21.7 & $<.5$ & $<1.5$ & $<2.0$ & $<.5$ & $<2.5$ & $<1.5$ & $<1.0$ \\
\hline 324703097270901 & WWD.B16 0-1 & .5 & Lake bottom & $08 / 28 / 2006$ & 200636101 & 11.2 & $<1.0$ & $<3.0$ & $<4.0$ & $<1.0$ & $<5.0$ & $<3.0$ & $<2.0$ \\
\hline 324709097271201 & WWD.B17 0-2 & 1.0 & Lake bottom & $08 / 28 / 2006$ & 200703201 & 10.7 & $<1.0$ & $<3.0$ & $<4.0$ & $<1.0$ & $<5.0$ & $<3.0$ & $<2.0$ \\
\hline \multicolumn{14}{|c|}{ Sediment quality guidelines } \\
\hline Threshold effect con & ncentration $(\text { TEC })^{2}$ & -- & - & - & -- & - & -- & -- & - & 2.37 & 4.88 & 3.16 & 4.16 \\
\hline Probable effect conc & centration $(\mathrm{PEC})^{2}$ & - & - & - & - & - & - - & - & - & 4.99 & 28.0 & 31.3 & 62.9 \\
\hline
\end{tabular}

Footnotes at end of table. 
Appendix 2. Polychlorinated biphenyl (PCB) Aroclor and congener, organic carbon, and organochlorine pesticide concentrations in suspended, streambed, and lake-bottom sediment samples from sites in and near Meandering Road Creek and Woods Inlet of Lake Worth, Fort Worth, Texas, 2004 and 2006-07-Continued.

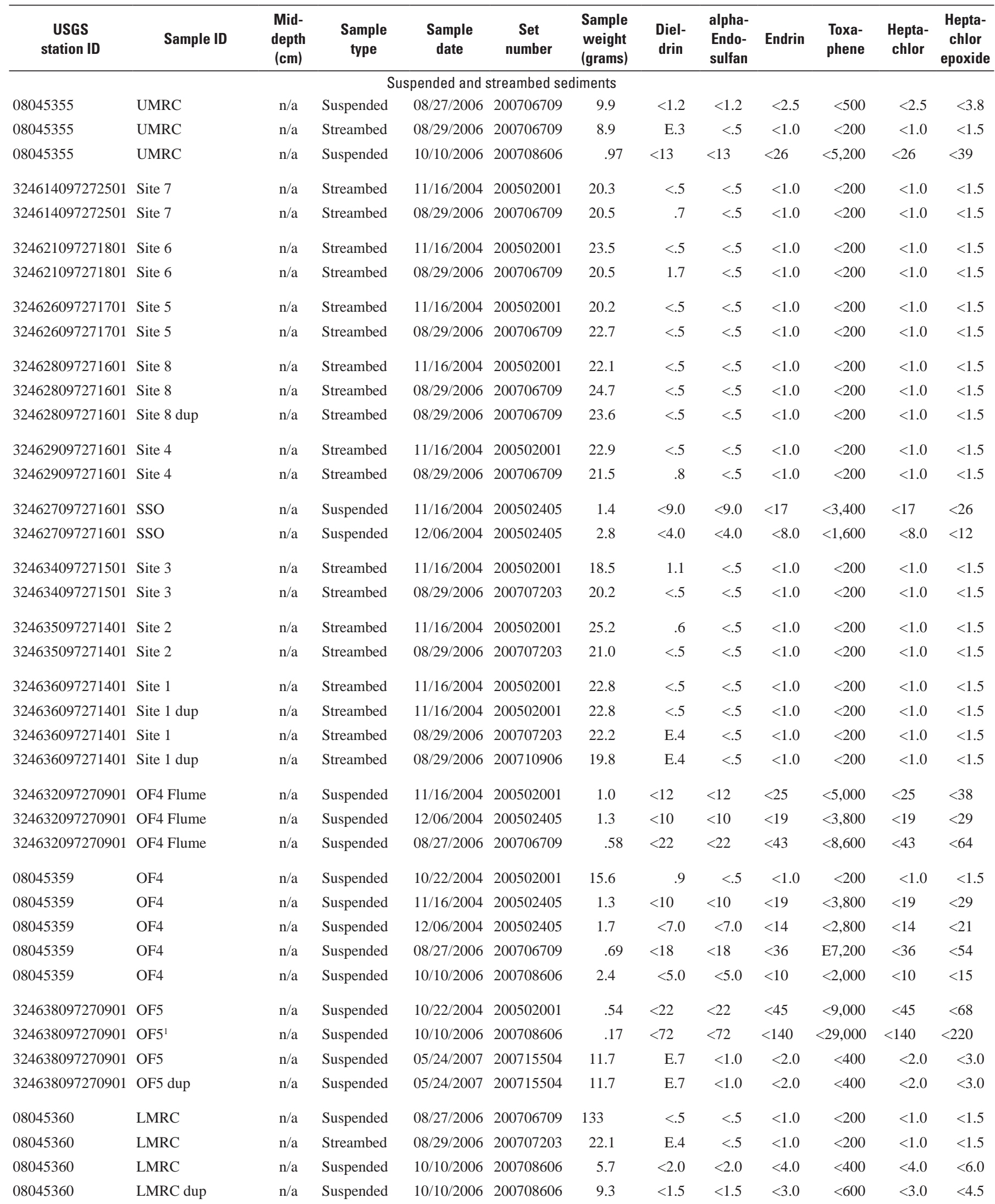

Footnotes at end of table. 
Appendix 2. Polychlorinated biphenyl (PCB) Aroclor and congener, organic carbon, and organochlorine pesticide concentrations in suspended, streambed, and lake-bottom sediment samples from sites in and near Meandering Road Creek and Woods Inlet of Lake Worth, Fort Worth, Texas, 2004 and 2006-07-Continued.

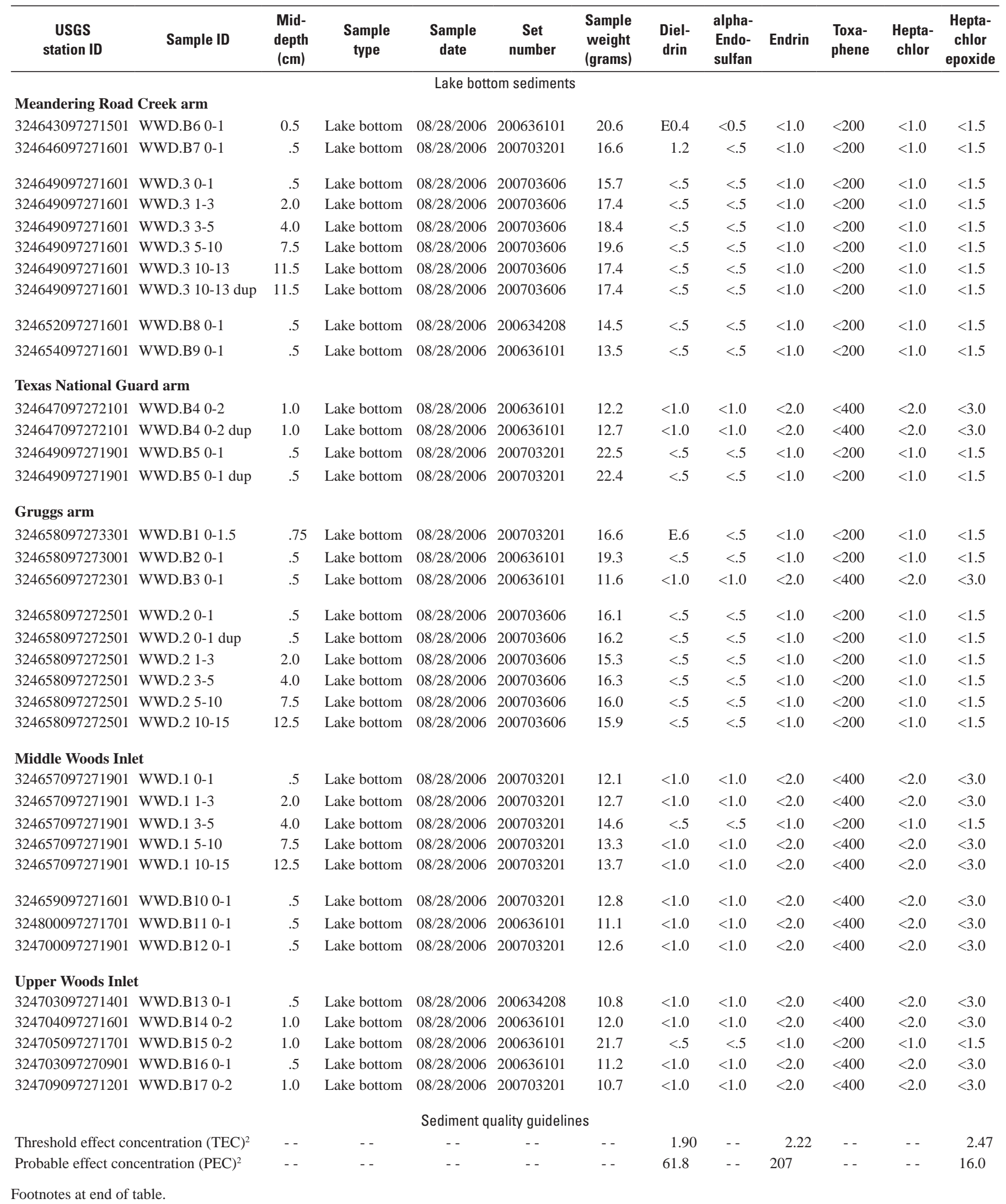


Appendix 2. Polychlorinated biphenyl (PCB) Aroclor and congener, organic carbon, and organochlorine pesticide concentrations in suspended, streambed, and lake-bottom sediment samples from sites in and near Meandering Road Creek and Woods Inlet of Lake Worth, Fort Worth, Texas, 2004 and 2006-07-Continued.

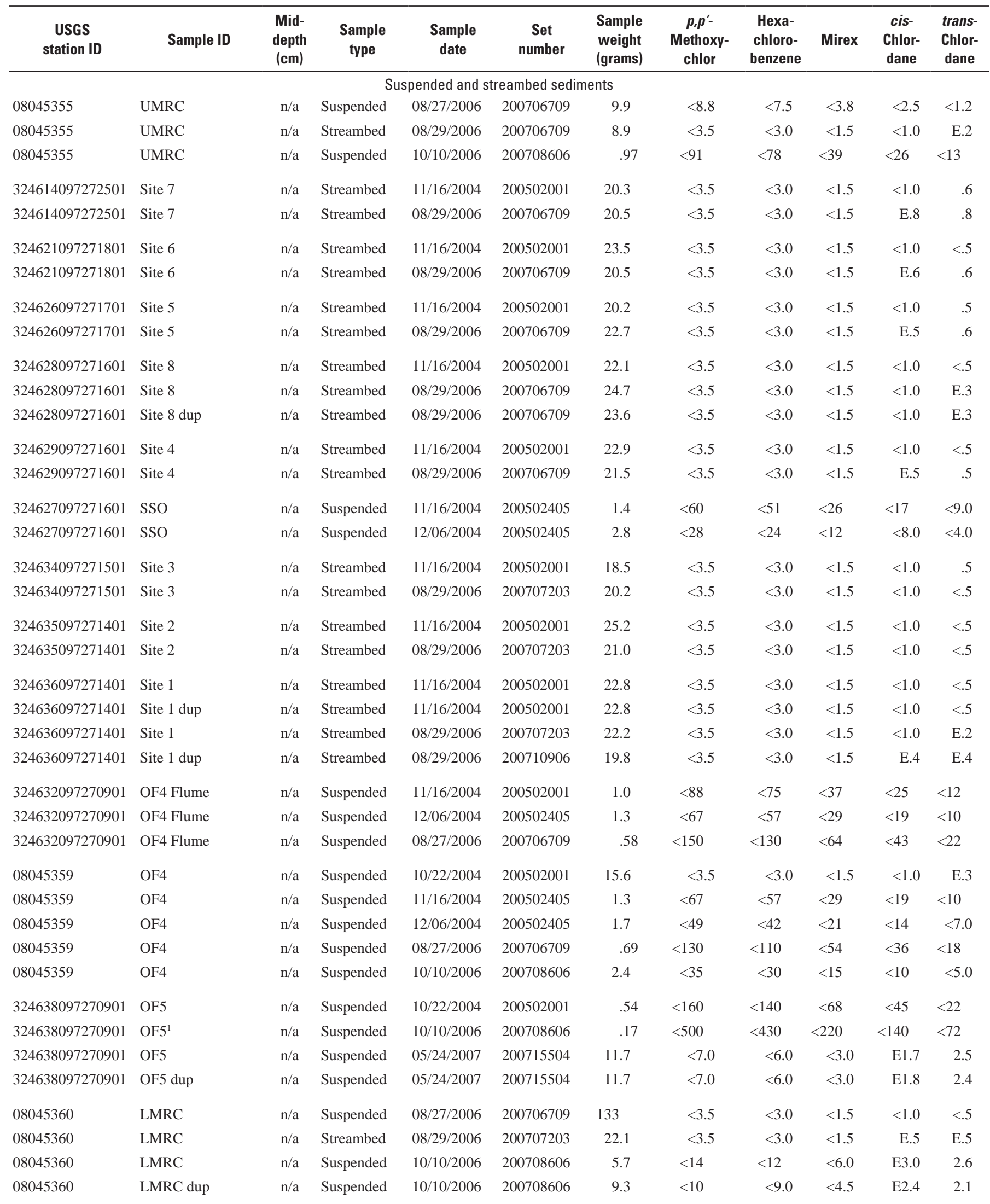

Footnotes at end of table. 
Appendix 2. Polychlorinated biphenyl (PCB) Aroclor and congener, organic carbon, and organochlorine pesticide concentrations in suspended, streambed, and lake-bottom sediment samples from sites in and near Meandering Road Creek and Woods Inlet of Lake Worth, Fort Worth, Texas, 2004 and 2006-07-Continued.

\begin{tabular}{|c|c|c|c|c|c|c|c|c|c|c|c|}
\hline $\begin{array}{c}\text { USGS } \\
\text { station ID }\end{array}$ & Sample ID & $\begin{array}{l}\text { Mid- } \\
\text { depth } \\
\text { (cm) }\end{array}$ & $\begin{array}{l}\text { Sample } \\
\text { type }\end{array}$ & $\begin{array}{c}\text { Sample } \\
\text { date }\end{array}$ & $\begin{array}{c}\text { Set } \\
\text { number }\end{array}$ & $\begin{array}{l}\text { Sample } \\
\text { weight } \\
\text { (grams) }\end{array}$ & $\begin{array}{c}p_{,} p^{\prime}- \\
\text { Methoxy- } \\
\text { chlor }\end{array}$ & $\begin{array}{c}\text { Hexa- } \\
\text { chloro- } \\
\text { benzene }\end{array}$ & Mirex & $\begin{array}{c}\text { cis- } \\
\text { Chlor- } \\
\text { dane }\end{array}$ & $\begin{array}{l}\text { trans- } \\
\text { Chlor- } \\
\text { dane }\end{array}$ \\
\hline \multicolumn{12}{|c|}{ Lake bottom sediments } \\
\hline 324643097271501 & WWD.B6 0-1 & 0.5 & Lake bottom & $08 / 28 / 2006$ & 200636101 & 20.6 & $<3.5$ & $<3.0$ & $<1.5$ & $<1.0$ & E0.5 \\
\hline 324646097271601 & WWD.B7 0-1 & .5 & Lake bottom & $08 / 28 / 2006$ & 200703201 & 16.6 & $<3.5$ & $<3.0$ & $<1.5$ & 1.2 & 2.0 \\
\hline 324649097271601 & WWD.3 3-5 & 4.0 & Lake bottom & $08 / 28 / 2006$ & 200703606 & 18.4 & $<3.5$ & $<3.0$ & $<1.5$ & E.5 & .6 \\
\hline 324649097271601 & WWD.3 5-10 & 7.5 & Lake bottom & $08 / 28 / 2006$ & 200703606 & 19.6 & $<3.5$ & $<3.0$ & $<1.5$ & E.4 & E. 5 \\
\hline 324649097271601 & WWD.3 10-13 & 11.5 & Lake bottom & $08 / 28 / 2006$ & 200703606 & 17.4 & $<3.5$ & $<3.0$ & $<1.5$ & E.5 & .7 \\
\hline 324649097271601 & WWD.3 10-13 dup & 11.5 & Lake bottom & $08 / 28 / 2006$ & 200703606 & 17.4 & $<3.5$ & $<3.0$ & $<1.5$ & E.4 & E. 3 \\
\hline 324647097272101 & WWD.B4 0-2 & 1.0 & Lake bottom & $08 / 28 / 2006$ & 200636101 & 12.2 & $<7.0$ & $<6.0$ & $<3.0$ & $<2.0$ & $<1.0$ \\
\hline 324647097272101 & WWD.B4 0-2 dup & 1.0 & Lake bottom & $08 / 28 / 2006$ & 200636101 & 12.7 & $<7.0$ & $<6.0$ & $<3.0$ & $<2.0$ & $<1.0$ \\
\hline 324649097271901 & WWD.B5 0-1 & .5 & Lake bottom & $08 / 28 / 2006$ & 200703201 & 22.5 & $<3.5$ & $<3.0$ & $<1.5$ & $<1.0$ & $<.5$ \\
\hline 324649097271901 & WWD.B5 0-1 dup & .5 & Lake bottom & $08 / 28 / 2006$ & 200703201 & 22.4 & $<3.5$ & $<3.0$ & $<1.5$ & $<1.0$ & $<.5$ \\
\hline \multicolumn{12}{|l|}{ Gruggs arm } \\
\hline 324658097273301 & WWD.B1 0-1.5 & .75 & Lake bottom & $08 / 28 / 2006$ & 200703201 & 16.6 & $<3.5$ & $<3.0$ & $<1.5$ & E.9 & 1.1 \\
\hline 324658097273001 & WWD.B2 0-1 & .5 & Lake bottom & $08 / 28 / 2006$ & 200636101 & 19.3 & $<3.5$ & $<3.0$ & $<1.5$ & $<1.0$ & $<.5$ \\
\hline 324656097272301 & WWD.B3 0-1 & .5 & Lake bottom & $08 / 28 / 2006$ & 200636101 & 11.6 & $<7.0$ & $<6.0$ & $<3.0$ & $<2.0$ & $<1.0$ \\
\hline 324658097272501 & WWD.2 0-1 & .5 & Lake bottom & $08 / 28 / 2006$ & 200703606 & 16.1 & $<3.5$ & $<3.0$ & $<1.5$ & E. 4 & E.4 \\
\hline 324658097272501 & WWD.2 0-1 dup & .5 & Lake bottom & $08 / 28 / 2006$ & 200703606 & 16.2 & $<3.5$ & $<3.0$ & $<1.5$ & E. 4 & E.4 \\
\hline 324657097271901 & WWD.1 3-5 & 4.0 & Lake bottom & $08 / 28 / 2006$ & 200703201 & 14.6 & $<3.5$ & $<3.0$ & $<1.5$ & $<1.0$ & E. 3 \\
\hline 324657097271901 & WWD.1 5-10 & 7.5 & Lake bottom & $08 / 28 / 2006$ & 200703201 & 13.3 & $<7.0$ & $<6.0$ & $<3.0$ & $<2.0$ & $<1.0$ \\
\hline 324657097271901 & WWD.1 10-15 & 12.5 & Lake bottom & $08 / 28 / 2006$ & 200703201 & 13.7 & $<7.0$ & $<6.0$ & $<3.0$ & $<2.0$ & $<1.0$ \\
\hline 324659097271601 & WWD.B10 0-1 & .5 & Lake bottom & $08 / 28 / 2006$ & 200703201 & 12.8 & $<7.0$ & $<6.0$ & $<3.0$ & $<2.0$ & $<1.0$ \\
\hline 324800097271701 & WWD.B11 0-1 & .5 & Lake bottom & $08 / 28 / 2006$ & 200636101 & 11.1 & $<7.0$ & $<6.0$ & $<3.0$ & $<2.0$ & $<1.0$ \\
\hline 324700097271901 & WWD.B12 0-1 & .5 & Lake bottom & $08 / 28 / 2006$ & 200703201 & 12.6 & $<7.0$ & $<6.0$ & $<3.0$ & $<2.0$ & $<1.0$ \\
\hline \multicolumn{12}{|l|}{ Upper Woods Inlet } \\
\hline 324703097271401 & WWD.B13 0-1 & .5 & Lake bottom & $08 / 28 / 2006$ & 200634208 & 10.8 & $<7.0$ & $<6.0$ & $<3.0$ & $<2.0$ & $<1.0$ \\
\hline 324704097271601 & WWD.B14 0-2 & 1.0 & Lake bottom & $08 / 28 / 2006$ & 200636101 & 12.0 & $<7.0$ & $<6.0$ & $<3.0$ & $<2.0$ & $<1.0$ \\
\hline 324705097271701 & WWD.B15 0-2 & 1.0 & Lake bottom & $08 / 28 / 2006$ & 200636101 & 21.7 & $<3.5$ & $<3.0$ & $<1.5$ & $<1.0$ & $<.5$ \\
\hline 324703097270901 & WWD.B16 0-1 & .5 & Lake bottom & $08 / 28 / 2006$ & 200636101 & 11.2 & $<7.0$ & $<6.0$ & $<3.0$ & $<2.0$ & $<1.0$ \\
\hline 324709097271201 & WWD.B17 0-2 & 1.0 & Lake bottom & $08 / 28 / 2006$ & 200703201 & 10.7 & $<7.0$ & $<6.0$ & $<3.0$ & $<2.0$ & $<1.0$ \\
\hline \multicolumn{12}{|c|}{ Sediment quality guidelines } \\
\hline Threshold effect con & ncentration $(\mathrm{TEC})^{2}$ & - & -- & -- & - & - & - & - & - & - & - \\
\hline Probable effect conc & centration $(\mathrm{PEC})^{2}$ & -- & - - & - - & -- & -- & -- & -- & -- & -- & -- \\
\hline
\end{tabular}

Footnotes at end of table. 
Appendix 2. Polychlorinated biphenyl (PCB) Aroclor and congener, organic carbon, and organochlorine pesticide concentrations in suspended, streambed, and lake-bottom sediment samples from sites in and near Meandering Road Creek and Woods Inlet of Lake Worth, Fort Worth, Texas, 2004 and 2006-07-Continued.

\begin{tabular}{|c|c|c|c|c|c|c|c|c|c|c|}
\hline \multirow{2}{*}{$\begin{array}{l}\text { USGS } \\
\text { station ID }\end{array}$} & \multirow{2}{*}{ Sample ID } & \multirow{2}{*}{$\begin{array}{c}\text { Mid- } \\
\text { depth } \\
\text { (cm) }\end{array}$} & \multirow{2}{*}{$\begin{array}{l}\text { Sample } \\
\text { type }\end{array}$} & \multirow{2}{*}{$\begin{array}{l}\text { Sample } \\
\text { date }\end{array}$} & \multirow{2}{*}{$\begin{array}{c}\text { Set } \\
\text { number }\end{array}$} & \multirow{2}{*}{$\begin{array}{c}\text { Sample } \\
\text { weight } \\
\text { (grams) }\end{array}$} & \multirow{2}{*}{$\begin{array}{c}\text { trans- } \\
\text { Nona- } \\
\text { chlor }\end{array}$} & \multicolumn{3}{|c|}{$\begin{array}{l}\text { Surrogates, percent recovery } \\
\text { (acceptable range) }\end{array}$} \\
\hline & & & & & & & & Isodrin & $\begin{array}{l}\text { alpha- } \\
\text { HCH-d6 }\end{array}$ & $\begin{array}{c}\text { Nonachloro- } \\
\text { biphenyl }\end{array}$ \\
\hline 08045355 & UMRC & $\mathrm{n} / \mathrm{a}$ & Suspended & $08 / 27 / 2006$ & 200706709 & 9.9 & $<2.5$ & $53(41-121)$ & $74(58-124)$ & $62(14-142)$ \\
\hline 08045355 & UMRC & $\mathrm{n} / \mathrm{a}$ & Streambed & $08 / 29 / 2006$ & 200706709 & 8.9 & $<1.0$ & $78(41-121)$ & $82(58-124)$ & $80(14-142)$ \\
\hline 324614097272501 & Site 7 & $\mathrm{n} / \mathrm{a}$ & Streambed & $11 / 16 / 2004$ & 200502001 & 20.3 & E. 8 & $68(42-94)$ & $74(21-140)$ & $150(19-125)$ \\
\hline 324614097272501 & Site 7 & $\mathrm{n} / \mathrm{a}$ & Streambed & $08 / 29 / 2006$ & 200706709 & 20.5 & 1.3 & $74(41-121)$ & $86(58-124)$ & $79(14-142)$ \\
\hline 324621097271801 & Site 6 & $\mathrm{n} / \mathrm{a}$ & Streambed & $11 / 16 / 2004$ & 200502001 & 23.5 & $<1.0$ & $75(42-94)$ & $55(21-140)$ & $140(19-125)$ \\
\hline 324621097271801 & Site 6 & $\mathrm{n} / \mathrm{a}$ & Streambed & 08/29/2006 & 200706709 & 20.5 & E. 9 & $50(41-121)$ & $87(58-124)$ & $56(14-142)$ \\
\hline 324628097271601 & Site 8 & $\mathrm{n} / \mathrm{a}$ & Streambed & $08 / 29 / 2006$ & 200706709 & 24.7 & $<1.0$ & $68(41-121)$ & $85(58-124)$ & $70(14-142)$ \\
\hline 324628097271601 & Site 8 dup & $\mathrm{n} / \mathrm{a}$ & Streambed & 08/29/2006 & 200706709 & 23.6 & $<1.0$ & $63(41-121)$ & $84(58-124)$ & $67(14-142)$ \\
\hline 324629097271601 & Site 4 & $\mathrm{n} / \mathrm{a}$ & Streambed & $11 / 16 / 2004$ & 200502001 & 22.9 & $<1.0$ & $66(42-94)$ & $74(21-140)$ & $130(19-125)$ \\
\hline 324629097271601 & Site 4 & $\mathrm{n} / \mathrm{a}$ & Streambed & $08 / 29 / 2006$ & 200706709 & 21.5 & E. 8 & $63(41-121)$ & $88(58-124)$ & $62(14-142)$ \\
\hline 324627097271601 & SSO & $\mathrm{n} / \mathrm{a}$ & Suspended & $11 / 16 / 2004$ & 200502405 & 1.4 & $<17$ & $48(42-94)$ & $79(21-140)$ & $120(19-125)$ \\
\hline 324627097271601 & SSO & $\mathrm{n} / \mathrm{a}$ & Suspended & $12 / 06 / 2004$ & 200502405 & 2.8 & $<8.0$ & $50(42-94)$ & $68(21-140)$ & $98(19-125)$ \\
\hline 324634097271501 & Site 3 & $\mathrm{n} / \mathrm{a}$ & Streambed & $11 / 16 / 2004$ & 200502001 & 18.5 & $<1.0$ & $52(42-94)$ & $82(21-140)$ & $140(19-125)$ \\
\hline 324634097271501 & Site 3 & $\mathrm{n} / \mathrm{a}$ & Streambed & $08 / 29 / 2006$ & 200707203 & 20.2 & $<1.0$ & $72(41-121)$ & $68(58-124)$ & $94(14-142)$ \\
\hline 324635097271401 & Site 2 & $\mathrm{n} / \mathrm{a}$ & Streambed & $11 / 16 / 2004$ & 200502001 & 25.2 & $<1.0$ & $49(42-94)$ & $62(21-140)$ & $130(19-125)$ \\
\hline 324632097270901 & OF4 Flume & $\mathrm{n} / \mathrm{a}$ & Suspended & $11 / 16 / 2004$ & 200502001 & 1.0 & $<25$ & $59(42-94)$ & $77(21-140)$ & $120(19-125)$ \\
\hline 324632097270901 & OF4 Flume & $\mathrm{n} / \mathrm{a}$ & Suspended & $12 / 06 / 2004$ & 200502405 & 1.3 & $<19$ & $49(42-94)$ & $74(21-140)$ & $90(19-125)$ \\
\hline 324632097270901 & OF4 Flume & $\mathrm{n} / \mathrm{a}$ & Suspended & $08 / 27 / 2006$ & 200706709 & .58 & $<43$ & $71(41-121)$ & $77(58-124)$ & $76(14-142)$ \\
\hline 08045359 & OF4 & $\mathrm{n} / \mathrm{a}$ & Suspended & $10 / 22 / 2004$ & 200502001 & 15.6 & $<1.0$ & $69(42-94)$ & $79(21-140)$ & $170(19-125)$ \\
\hline 08045359 & OF4 & $\mathrm{n} / \mathrm{a}$ & Suspended & $11 / 16 / 2004$ & 200502405 & 1.3 & $<19$ & $57(42-94)$ & $77(21-140)$ & $120(19-125)$ \\
\hline 08045359 & OF4 & $\mathrm{n} / \mathrm{a}$ & Suspended & $12 / 06 / 2004$ & 200502405 & 1.7 & $<14$ & $61(42-94)$ & $85(21-140)$ & $110(19-125)$ \\
\hline 08045359 & OF4 & $\mathrm{n} / \mathrm{a}$ & Suspended & $08 / 27 / 2006$ & 200706709 & .69 & $<36$ & $72(41-121)$ & $83(58-124)$ & $76(14-142)$ \\
\hline 08045359 & OF4 & $\mathrm{n} / \mathrm{a}$ & Suspended & $10 / 10 / 2006$ & 200708606 & 2.4 & $<10$ & $76(41-121)$ & $75(58-124)$ & $81(14-142)$ \\
\hline 324638097270901 & OF5 & $\mathrm{n} / \mathrm{a}$ & Suspended & $10 / 22 / 2004$ & 200502001 & .54 & $<45$ & $76(42-94)$ & $83(21-140)$ & $140(19-125)$ \\
\hline 324638097270901 & OF5 ${ }^{1}$ & $\mathrm{n} / \mathrm{a}$ & Suspended & $10 / 10 / 2006$ & 200708606 & .17 & $<140$ & $87(41-121)$ & $82(58-124)$ & $88(14-142)$ \\
\hline 324638097270901 & OF5 & $\mathrm{n} / \mathrm{a}$ & Suspended & $05 / 24 / 2007$ & 200715504 & 11.7 & $<2.0$ & $50(41-121)$ & $66(58-124)$ & $92(14-142)$ \\
\hline 324638097270901 & OF5 dup & $\mathrm{n} / \mathrm{a}$ & Suspended & $05 / 24 / 2007$ & 200715504 & 11.7 & $<2.0$ & $50(41-121)$ & $62(58-124)$ & $90(14-142)$ \\
\hline 08045360 & LMRC & $\mathrm{n} / \mathrm{a}$ & Suspended & $08 / 27 / 2006$ & 200706709 & 133 & $<1.0$ & $50(41-121)$ & $76(58-124)$ & $60(14-142)$ \\
\hline 08045360 & LMRC & $\mathrm{n} / \mathrm{a}$ & Streambed & $08 / 29 / 2006$ & 200707203 & 22.1 & E.5 & $71(41-121)$ & $72(58-124)$ & $100(14-142)$ \\
\hline 08045360 & LMRC & $\mathrm{n} / \mathrm{a}$ & Suspended & $10 / 10 / 2006$ & 200708606 & 5.7 & 4.2 & $67(41-121)$ & $72(58-124)$ & $81(14-142)$ \\
\hline 08045360 & LMRC dup & $\mathrm{n} / \mathrm{a}$ & Suspended & $10 / 10 / 2006$ & 200708606 & 9.3 & 3.5 & $59(41-121)$ & $74(58-124)$ & $76(14-142)$ \\
\hline
\end{tabular}

Footnotes at end of table. 
Appendix 2. Polychlorinated biphenyl (PCB) Aroclor and congener, organic carbon, and organochlorine pesticide concentrations in suspended, streambed, and lake-bottom sediment samples from sites in and near Meandering Road Creek and Woods Inlet of Lake Worth, Fort Worth, Texas, 2004 and 2006-07-Continued.

\begin{tabular}{|c|c|c|c|c|c|c|c|c|c|c|}
\hline \multirow{2}{*}{$\begin{array}{c}\text { USGS } \\
\text { station ID }\end{array}$} & \multirow{2}{*}{ Sample ID } & \multirow{2}{*}{$\begin{array}{l}\text { Mid- } \\
\text { depth } \\
\text { (cm) }\end{array}$} & \multirow{2}{*}{$\begin{array}{c}\text { Sample } \\
\text { type }\end{array}$} & \multirow{2}{*}{$\begin{array}{l}\text { Sample } \\
\text { date }\end{array}$} & \multirow{2}{*}{$\begin{array}{c}\text { Set } \\
\text { number }\end{array}$} & \multirow{2}{*}{$\begin{array}{c}\text { Sample } \\
\text { weight } \\
\text { (grams) }\end{array}$} & \multirow{2}{*}{$\begin{array}{l}\text { trans- } \\
\text { Nona- } \\
\text { chlor }\end{array}$} & \multicolumn{3}{|c|}{$\begin{array}{c}\text { Surrogates, percent recovery } \\
\text { (acceptable range) }\end{array}$} \\
\hline & & & & & & & & Isodrin & $\begin{array}{l}\text { alpha- } \\
\text { HCH-d6 }\end{array}$ & $\begin{array}{c}\text { Nonachloro- } \\
\text { biphenyl }\end{array}$ \\
\hline \multicolumn{11}{|c|}{ Lake bottom sediments } \\
\hline \multicolumn{11}{|c|}{ M eandering $\mathrm{R}$ oad $\mathrm{C}$ reek arm } \\
\hline 324643097271501 & WWD.B6 0-1 & 0.5 & Lake bottom & $08 / 28 / 2006$ & 200636101 & 20.6 & $<1.0$ & $62(41-121)$ & $110(58-124)$ & $97(14-142)$ \\
\hline 324649097271601 & WWD.3 1-3 & 2.0 & Lake bottom & $08 / 28 / 2006$ & 200703606 & 17.4 & E. 4 & $70(41-121)$ & $82(58-124)$ & $78(14-142)$ \\
\hline 324649097271601 & WWD.3 3-5 & 4.0 & Lake bottom & $08 / 28 / 2006$ & 200703606 & 18.4 & E.5 & $75(41-121)$ & $90(58-124)$ & $84(14-142)$ \\
\hline 324649097271601 & WWD.3 5-10 & 7.5 & Lake bottom & $08 / 28 / 2006$ & 200703606 & 19.6 & E. 4 & $76(41-121)$ & $85(58-124)$ & $82(14-142)$ \\
\hline 324649097271601 & WWD.3 10-13 & 11.5 & Lake bottom & $08 / 28 / 2006$ & 200703606 & 17.4 & $<1.0$ & $72(41-121)$ & $66(58-124)$ & $76(14-142)$ \\
\hline 324649097271601 & WWD.3 10-13 dup & 11.5 & Lake bottom & $08 / 28 / 2006$ & 200703606 & 17.4 & $<1.0$ & $64(41-121)$ & $73(58-124)$ & $71(14-142)$ \\
\hline 324647097272101 & WWD.B4 0-2 & 1.0 & Lake bottom & $08 / 28 / 2006$ & 200636101 & 12.2 & $<2.0$ & $74(41-121)$ & $88(58-124)$ & $98(14-142)$ \\
\hline 324647097272101 & WWD.B4 0-2 dup & 1.0 & Lake bottom & $08 / 28 / 2006$ & 200636101 & 12.7 & $<2.0$ & $74(41-121)$ & $98(58-124)$ & $96(14-142)$ \\
\hline 324649097271901 & WWD.B5 0-1 & .5 & Lake bottom & $08 / 28 / 2006$ & 200703201 & 22.5 & $<1.0$ & $88(41-121)$ & $94(58-124)$ & $92(14-142)$ \\
\hline 324649097271901 & WWD.B5 0-1 dup & .5 & Lake bottom & $08 / 28 / 2006$ & 200703201 & 22.4 & $<1.0$ & $110(41-121)$ & $90(58-124)$ & $110(14-142)$ \\
\hline \multicolumn{11}{|l|}{ Gruggs arm } \\
\hline 324658097273301 & WWD.B1 0-1.5 & .75 & Lake bottom & $08 / 28 / 2006$ & 200703201 & 16.6 & 1.1 & $73(41-121)$ & $87(58-124)$ & $82(14-142)$ \\
\hline 324658097273001 & WWD.B2 0-1 & .5 & Lake bottom & $08 / 28 / 2006$ & 200636101 & 19.3 & $<1.0$ & $69(41-121)$ & $46(58-124)$ & $88(14-142)$ \\
\hline 324656097272301 & WWD.B3 0-1 & .5 & Lake bottom & $08 / 28 / 2006$ & 200636101 & 11.6 & $<2.0$ & $60(41-121)$ & $100(58-124)$ & $82(14-142)$ \\
\hline 324658097272501 & WWD.2 0-1 & .5 & Lake bottom & $08 / 28 / 2006$ & 200703606 & 16.1 & E. 4 & $89(41-121)$ & $85(58-124)$ & $100(14-142)$ \\
\hline 324658097272501 & WWD.2 0-1 dup & .5 & Lake bottom & $08 / 28 / 2006$ & 200703606 & 16.2 & E.5 & $79(41-121)$ & $89(58-124)$ & $87(14-142)$ \\
\hline 324657097271901 & WWD.1 1-3 & 2.0 & Lake bottom & $08 / 28 / 2006$ & 200703201 & 12.7 & $<2.0$ & $75(41-121)$ & $81(58-124)$ & $78(14-142)$ \\
\hline 324657097271901 & WWD.1 3-5 & 4.0 & Lake bottom & $08 / 28 / 2006$ & 200703201 & 14.6 & $<1.0$ & $89(41-121)$ & $79(58-124)$ & $90(14-142)$ \\
\hline 324657097271901 & WWD.1 5-10 & 7.5 & Lake bottom & $08 / 28 / 2006$ & 200703201 & 13.3 & $<2.0$ & $87(41-121)$ & $110(58-124)$ & $86(14-142)$ \\
\hline 324657097271901 & WWD.1 10-15 & 12.5 & Lake bottom & $08 / 28 / 2006$ & 200703201 & 13.7 & $<2.0$ & $79(41-121)$ & $76(58-124)$ & $75(14-142)$ \\
\hline 324659097271601 & WWD.B10 0-1 & .5 & Lake bottom & $08 / 28 / 2006$ & 200703201 & 12.8 & $<2.0$ & $78(41-121)$ & $89(58-124)$ & $80(14-142)$ \\
\hline 324800097271701 & WWD.B11 0-1 & .5 & Lake bottom & $08 / 28 / 2006$ & 200636101 & 11.1 & $<2.0$ & $70(41-121)$ & $92(58-124)$ & $91(14-142)$ \\
\hline 324700097271901 & WWD.B12 0-1 & .5 & Lake bottom & $08 / 28 / 2006$ & 200703201 & 12.6 & $<2.0$ & $\begin{array}{l}\mathrm{E} 120 \\
\quad(41-121)\end{array}$ & $93(58-124)$ & $130(14-142)$ \\
\hline \multicolumn{11}{|l|}{ Upper Woods Inlet } \\
\hline 324703097271401 & WWD.B13 0-1 & .5 & Lake bottom & $08 / 28 / 2006$ & 200634208 & 10.8 & $<2.0$ & $63(41-121)$ & $75(58-124)$ & $77(14-142)$ \\
\hline 324704097271601 & WWD.B14 0-2 & 1.0 & Lake bottom & $08 / 28 / 2006$ & 200636101 & 12.0 & $<2.0$ & $60(41-121)$ & $89(58-124)$ & $77(14-142)$ \\
\hline 324705097271701 & WWD.B15 0-2 & 1.0 & Lake bottom & $08 / 28 / 2006$ & 200636101 & 21.7 & $<1.0$ & $88(41-121)$ & $88(58-124)$ & $100(14-142)$ \\
\hline 324703097270901 & WWD.B16 0-1 & .5 & Lake bottom & $08 / 28 / 2006$ & 200636101 & 11.2 & $<2.0$ & $70(41-121)$ & $96(58-124)$ & $84(14-142)$ \\
\hline 324709097271201 & WWD.B17 0-2 & 1.0 & Lake bottom & $08 / 28 / 2006$ & 200703201 & 10.7 & $<2.0$ & $78(41-121)$ & $80(58-124)$ & $74(14-142)$ \\
\hline \multicolumn{11}{|c|}{ Sediment quality guidelines } \\
\hline Threshold effect co & ncentration (TEC) $)^{2}$ & -- & -- & -- & - & -- & - & -- & -- & -- \\
\hline Probable effect con & centration $(\mathrm{PEC})^{2}$ & -- & - - & - & - & - - & - & - & - & - \\
\hline
\end{tabular}

\footnotetext{
${ }^{1}$ Sample required custom preparation (air dried) at the laboratory because normal centrifugation could not separate solids from water.
}

${ }^{2}$ MacDonald and others (2000). 


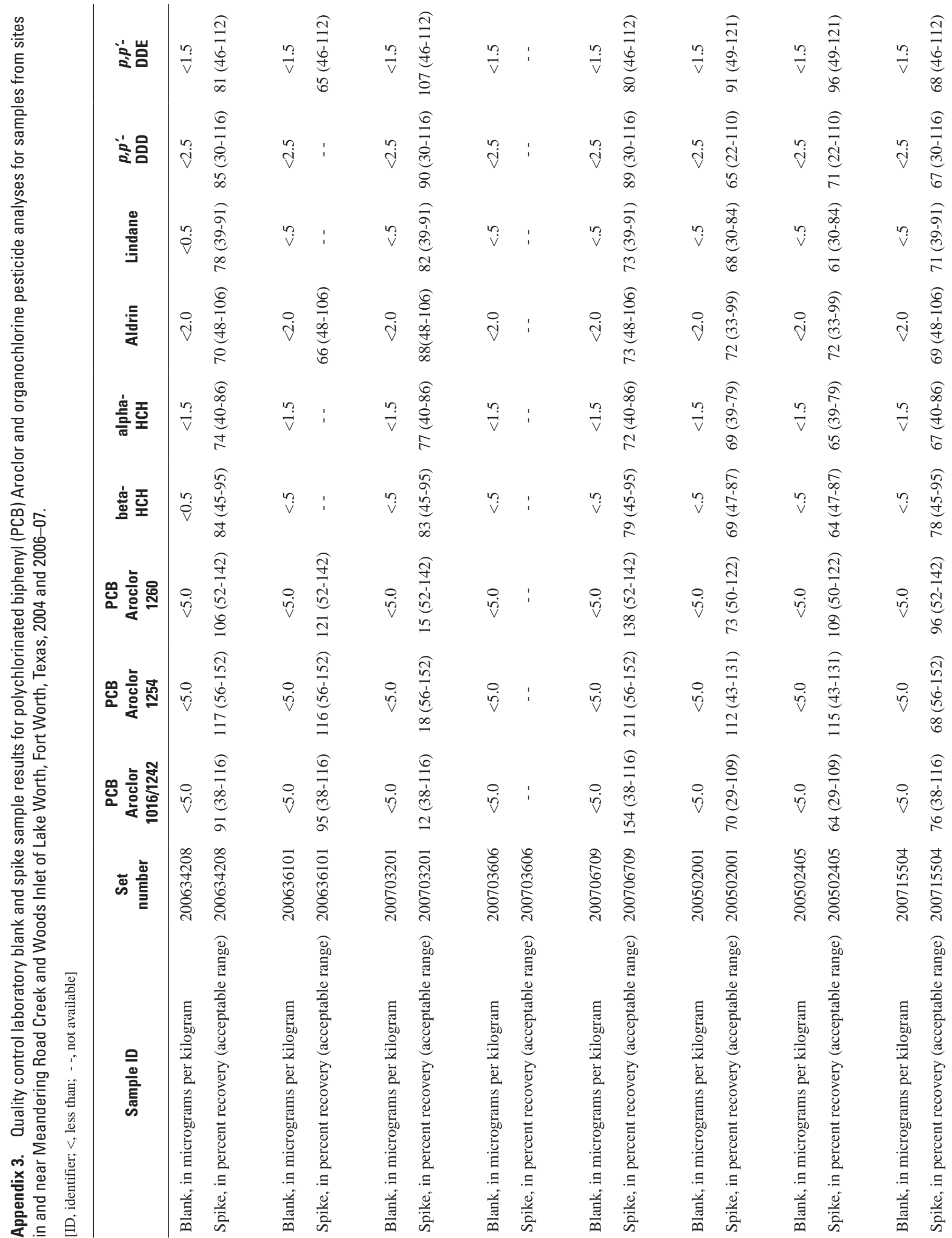




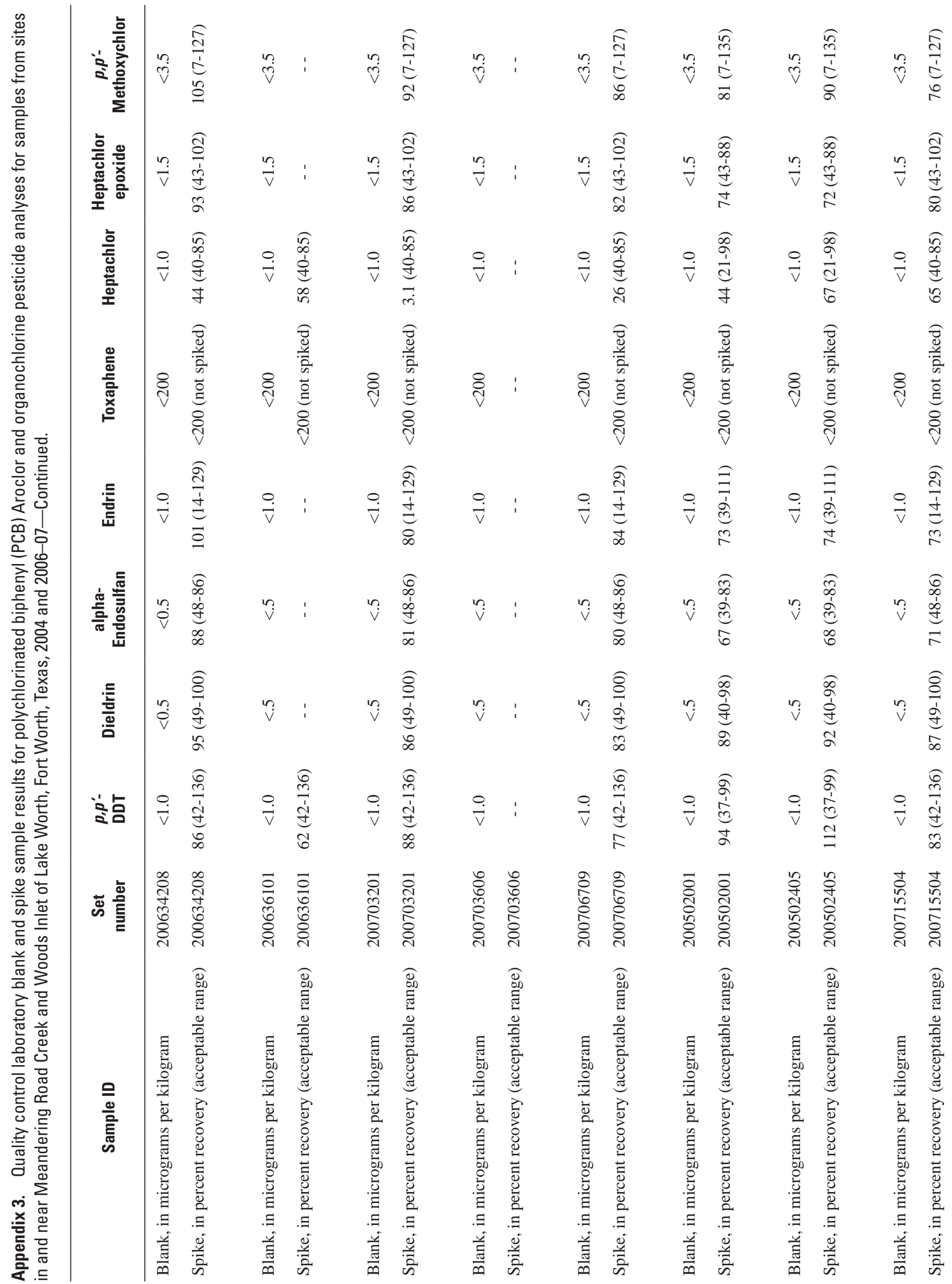




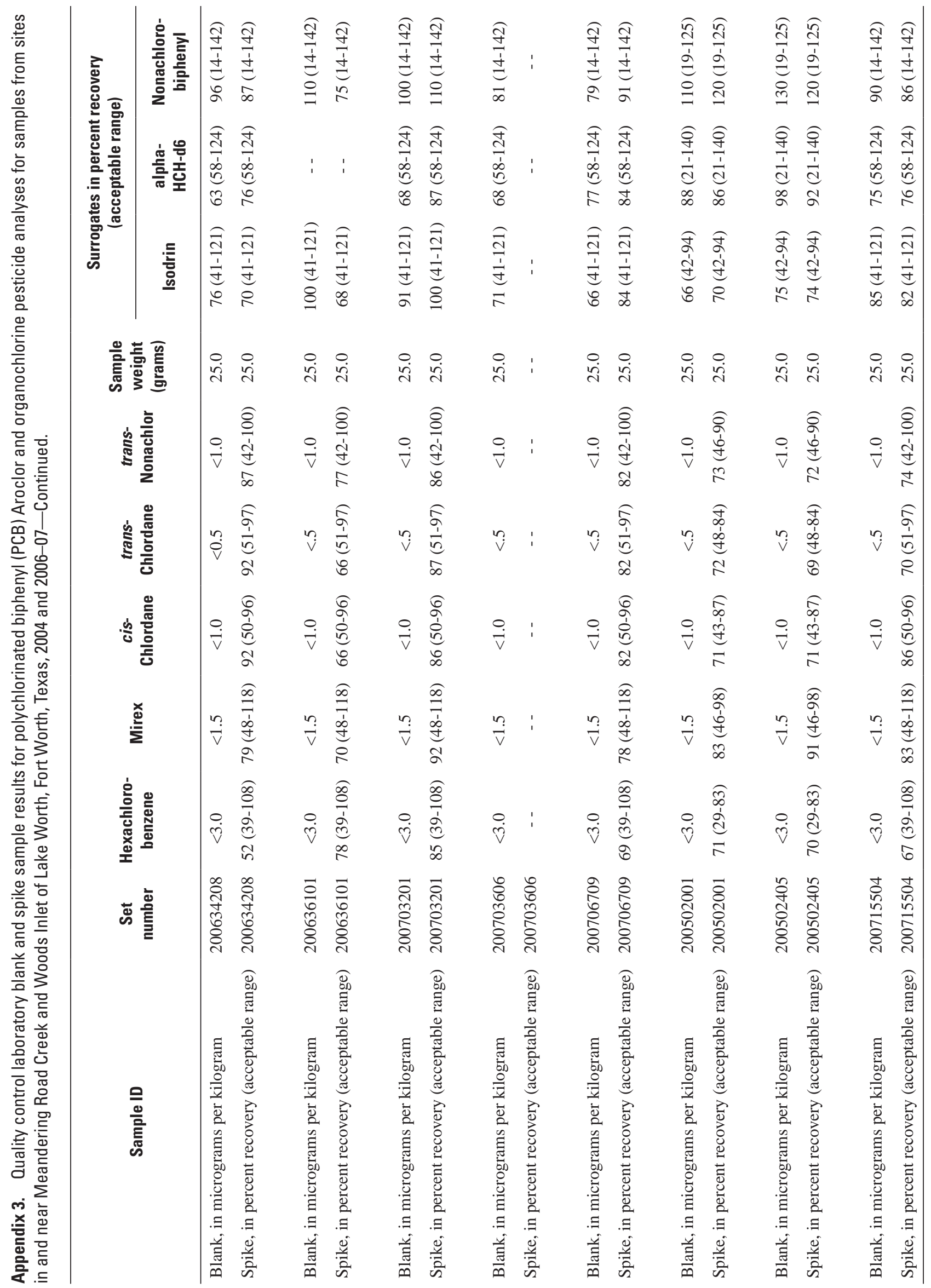




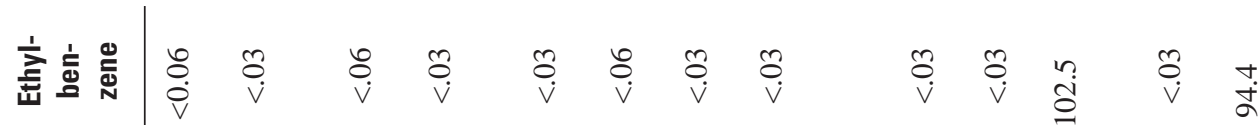

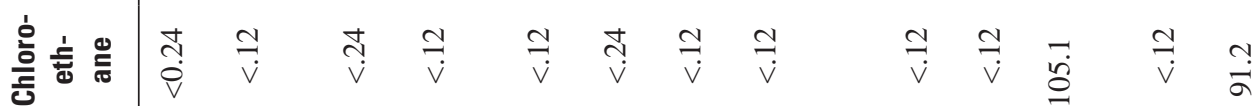
宰紊

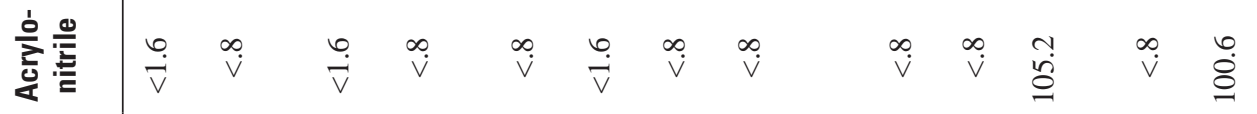

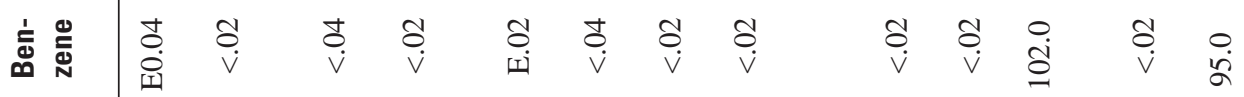
ま

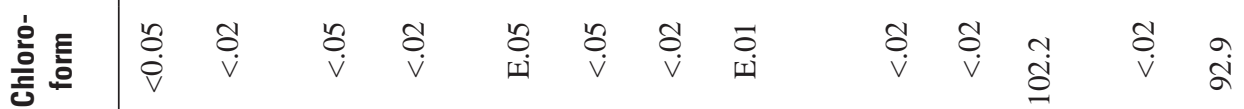

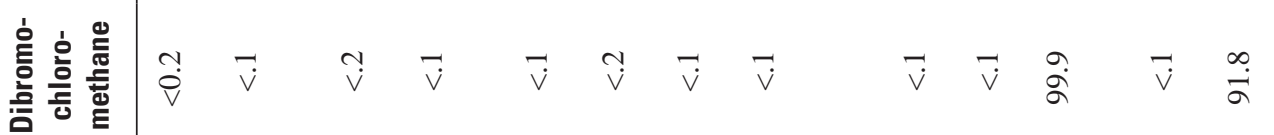

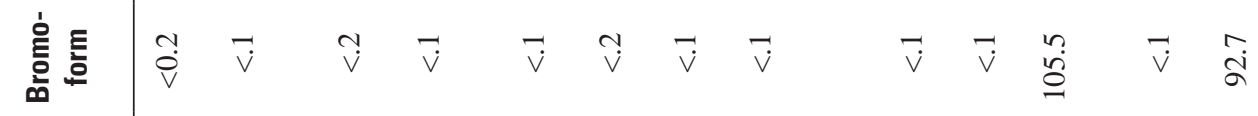

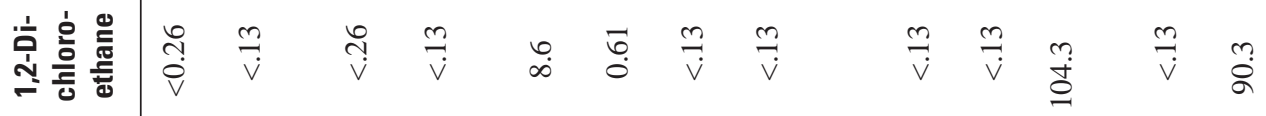

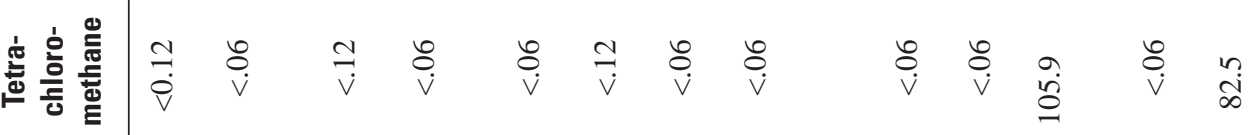

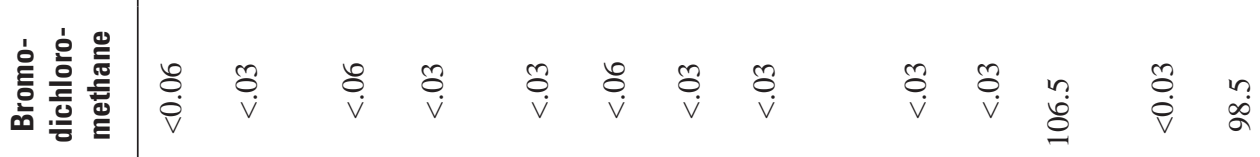

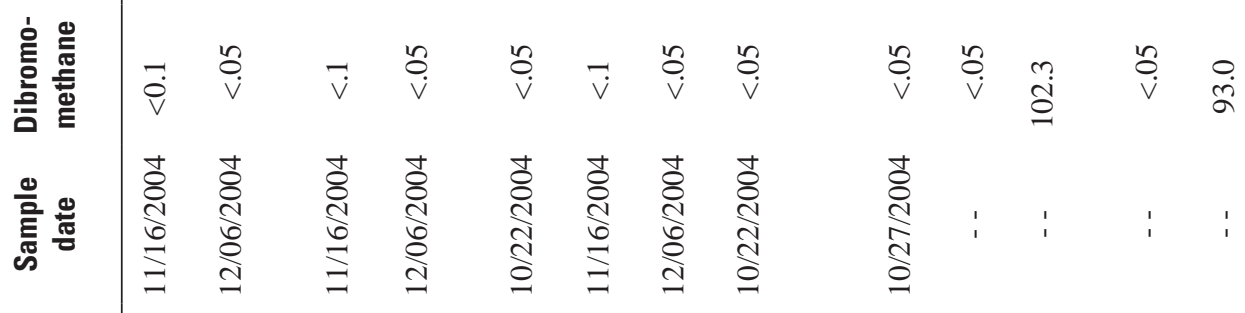


列

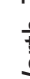

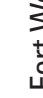

tᄒ

离

ฮั

ฮ

.

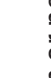

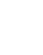$$
\text { . }
$$

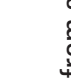

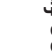

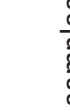$$
\text { . }
$$$$
5
$$$$
\text { . }
$$

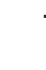$$
\text { 高 }
$$ 


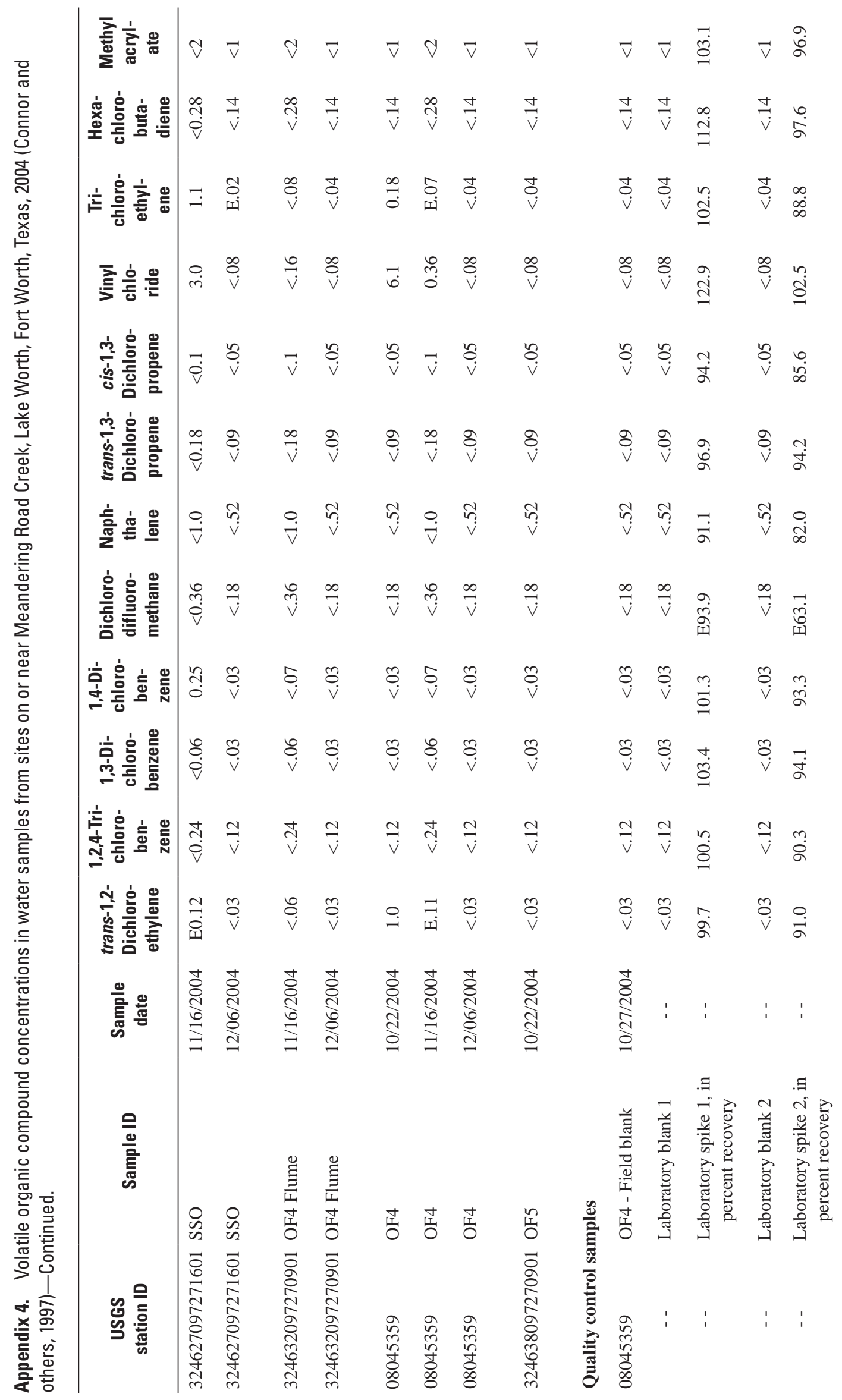




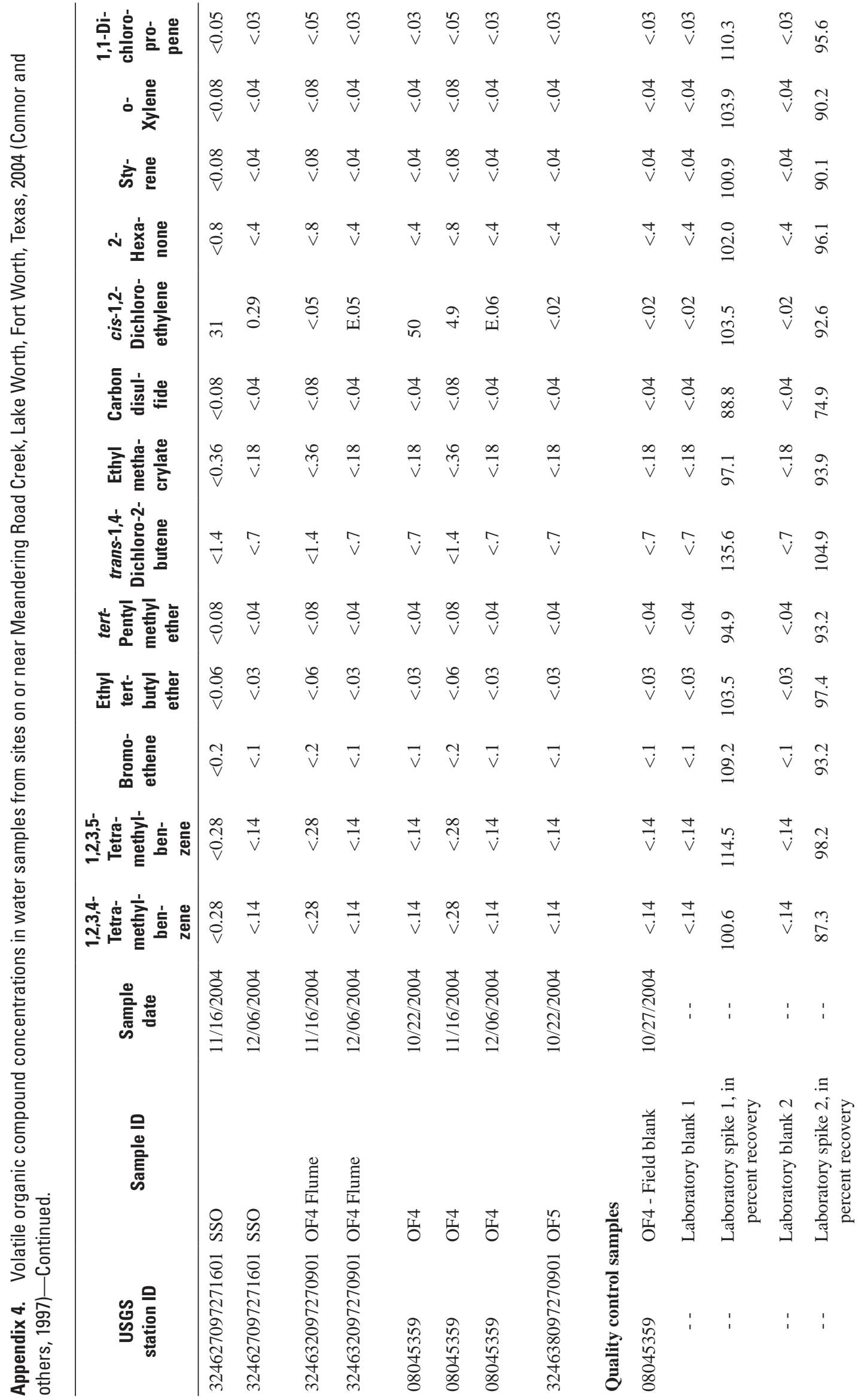




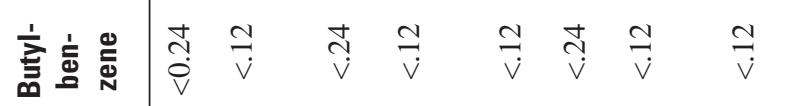

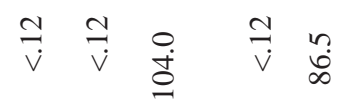

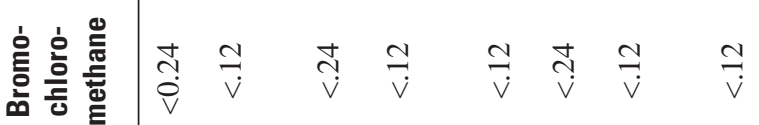

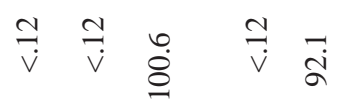

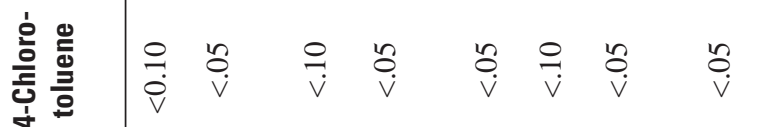

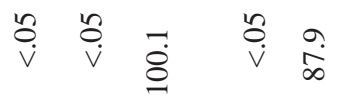

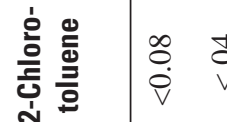

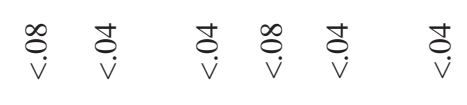

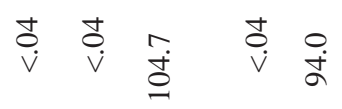

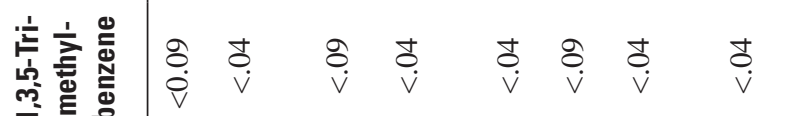

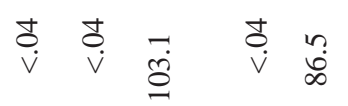

=

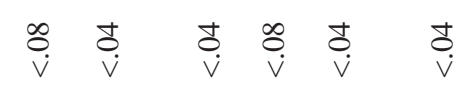

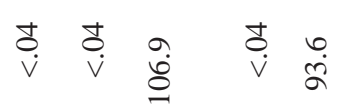

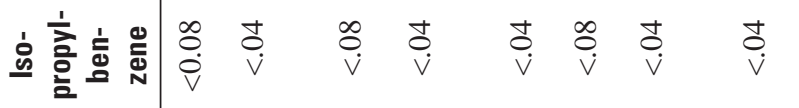

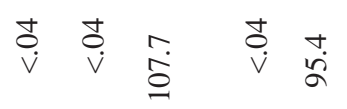

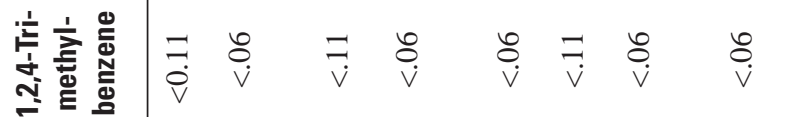

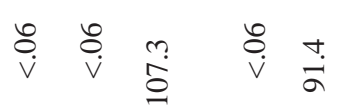

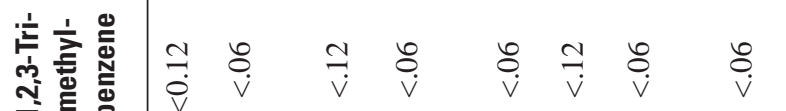

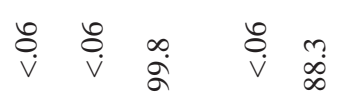

岦高

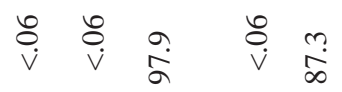

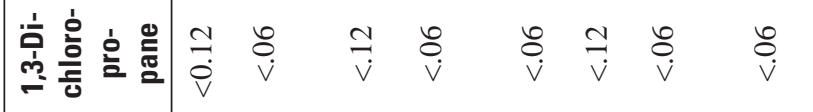

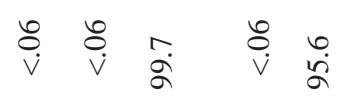

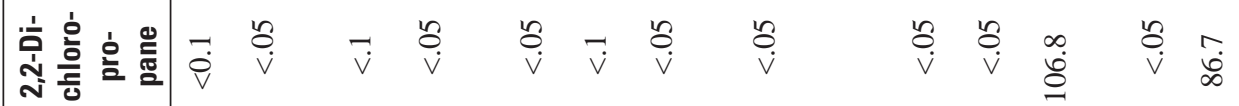

产 密

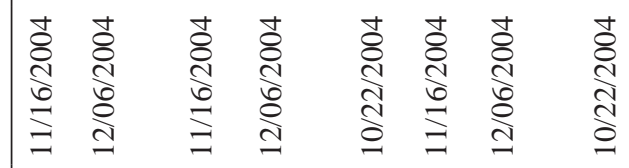

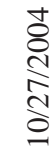




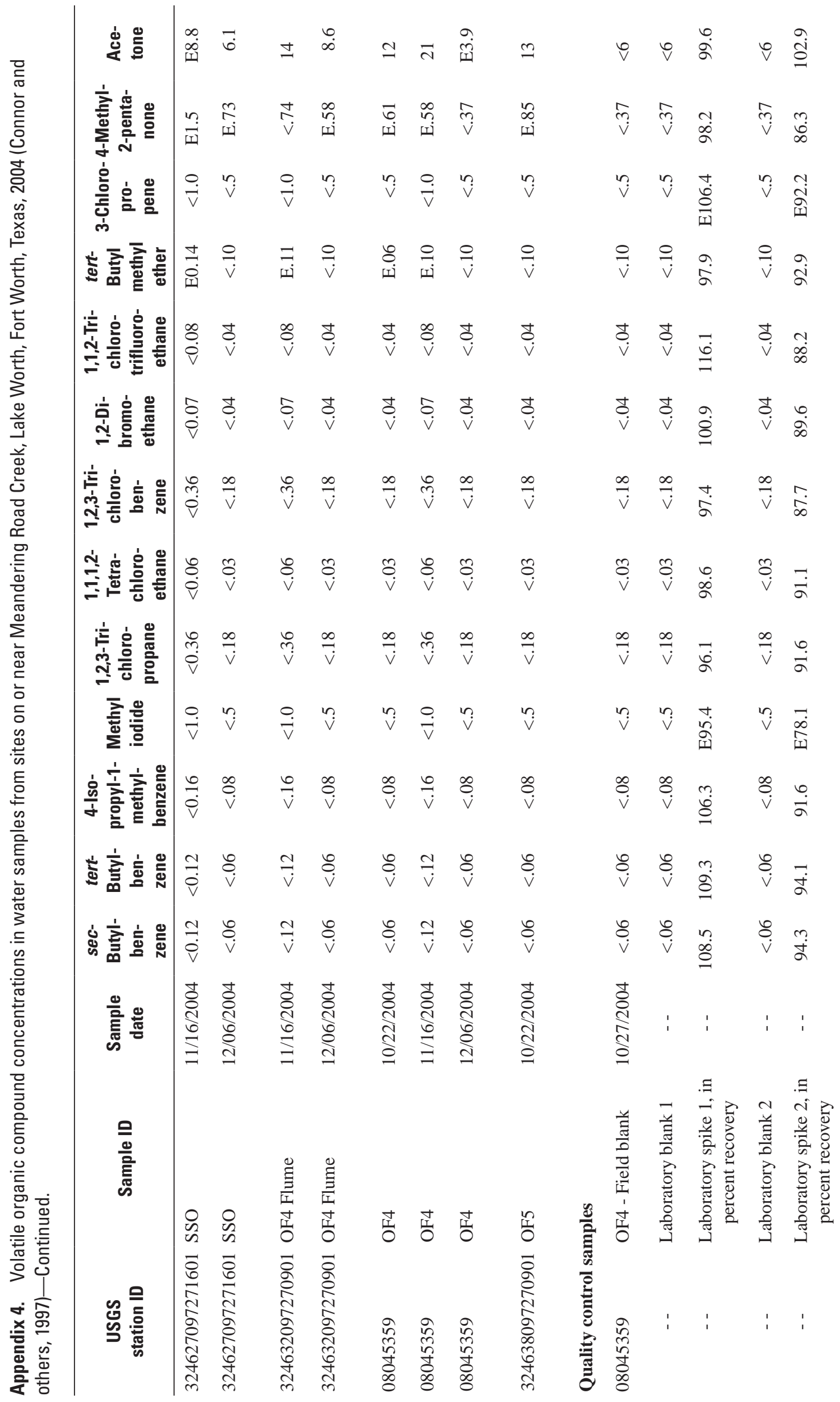




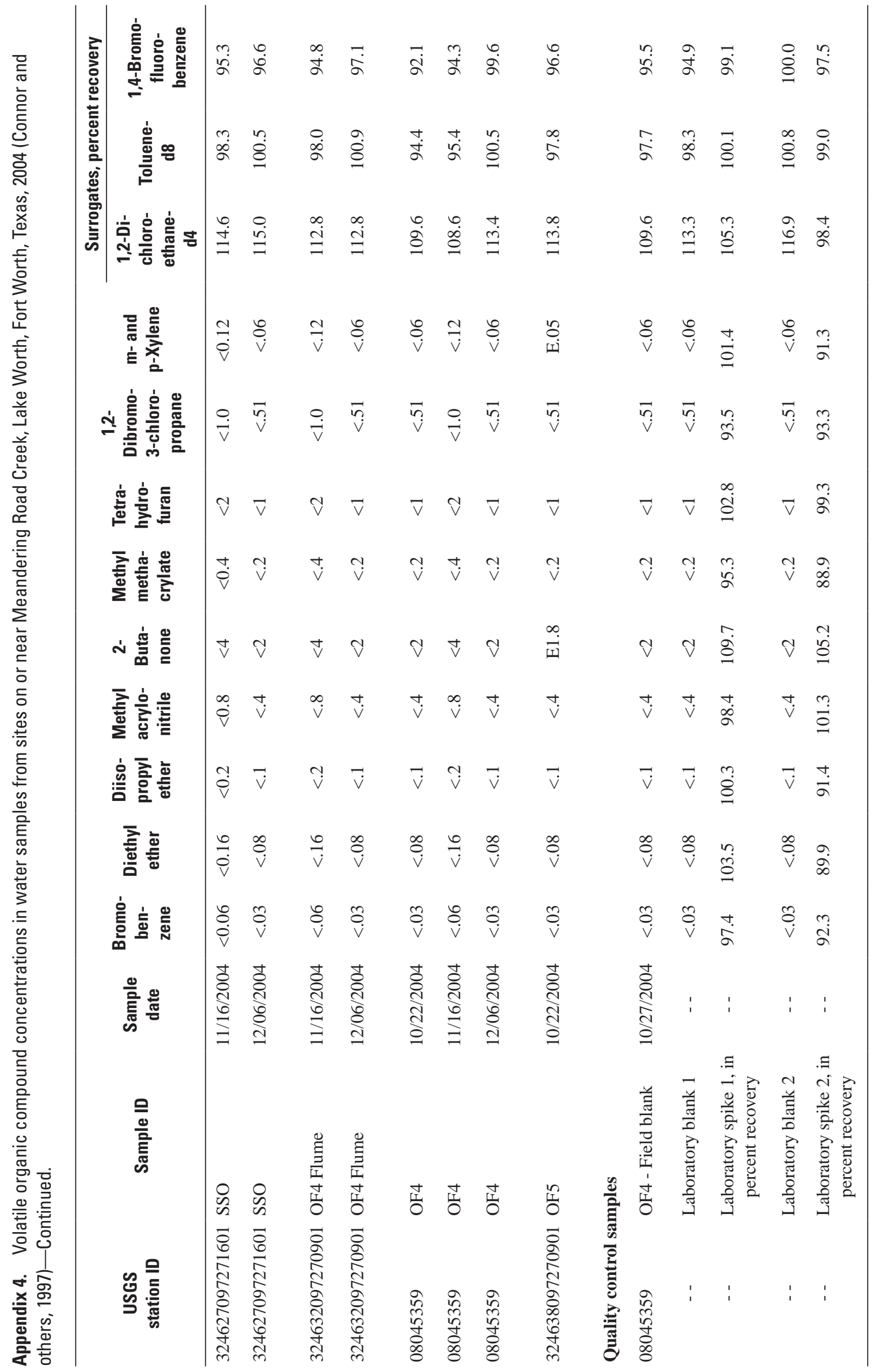


Appendix 5. Major and trace element concentrations in lake-bottom sediment samples from sites in Woods Inlet of Lake Worth, Fort Worth, Texas, 2006.

[In micrograms per gram except as noted. USGS, U.S. Geological Survey; ID, identifier; cm, centimeter; <, less than; - -, not applicable or not available; \%, percent]

\begin{tabular}{llccccccccc}
\hline \multicolumn{1}{c}{$\begin{array}{c}\text { USGS } \\
\text { station ID }\end{array}$} & Sample ID & $\begin{array}{c}\text { Mid- } \\
\text { depth } \\
\text { (cm) }\end{array}$ & $\begin{array}{c}\text { Sample } \\
\text { type }\end{array}$ & $\begin{array}{c}\text { Sample } \\
\text { date }\end{array}$ & $\begin{array}{c}\text { Organic } \\
\text { carbon, } \\
\text { percent }\end{array}$ & $\begin{array}{c}\text { Total } \\
\text { carbon, } \\
\text { percent }\end{array}$ & $\begin{array}{c}\text { Inorganic } \\
\text { carbon, } \\
\text { percent }\end{array}$ & Aluminum & Calcium & Iron \\
Potassium
\end{tabular}

Sediment quality guidelines

$\begin{array}{ll}-- & \mathrm{TEC}^{1} \\ - & \mathrm{PEC}^{1}\end{array}$

$\mathrm{TEC}^{1}$

Quality control samples

\begin{tabular}{|c|c|c|c|c|c|c|c|c|c|c|c|}
\hline -. & Blank 1 & - - & - - & - - & - & -. & -. & $<50$ & $<100$ & $<50$ & $<20$ \\
\hline -. & Blank 2 & -- & -. & - - & -. & - - & -. & $<50$ & $<100$ & $<50$ & $<20$ \\
\hline - & Blank 3 & - - & - - & - - & - - & - - & -. & $<50$ & $<100$ & $<50$ & $<20$ \\
\hline
\end{tabular}

Standard reference materials

\begin{tabular}{|c|c|c|c|c|c|c|c|c|c|c|c|}
\hline-- & MAG-1 laboratory & - & - - & -- & - & - & -- & 90,400 & 10,500 & 50,300 & 31,500 \\
\hline-- & MAG-1 published ${ }^{2}$ & -- & - - & - - & - - & - & - - & 86,660 & 9,790 & 47,600 & 29,500 \\
\hline - - & Percent recovery & - - & - - & - - & - - & - & - - & $104 \%$ & $107 \%$ & $106 \%$ & $107 \%$ \\
\hline - - & NIST 8704 laboratory & -. & -. & -. & - - & -. & - - & 65,100 & 27,400 & 41,800 & 20,900 \\
\hline - - & NIST 8704 published & - - & - - & - - & - - & - - & - - & 61,000 & 26,410 & 39,700 & 20,010 \\
\hline - - & Percent recovery & -. & -. & - - & - - & -. & - - & $107 \%$ & $104 \%$ & $105 \%$ & $104 \%$ \\
\hline - - & SCO-1 laboratory & - - & - - & - - & - - & -. & -. & 75,400 & 20,100 & 36,700 & 23,300 \\
\hline-- & GSD-8 laboratory & - - & - & - - & -- & -- & - - & 43,300 & 1,580 & 15,600 & 23,700 \\
\hline-- & GSD-8 published ${ }^{2}$ & - & - & - - & -- & - & -- & 40,800 & 1,790 & 15,380 & 23,500 \\
\hline -- & Percent recovery & - & - & - & -- & -- & -- & $106 \%$ & $88 \%$ & $101 \%$ & $101 \%$ \\
\hline -- & NIST 2709 laboratory & - - & -- & - - & - & - & -- & 75,100 & 19,800 & 35,700 & 20,400 \\
\hline -- & Percent recovery & -- & -- & - & -- & -- & -- & $114 \%$ & $106 \%$ & $105 \%$ & $108 \%$ \\
\hline - - & GSD-5 laboratory & -- & - - & - - & - - & -- & -- & 85,300 & 41,400 & 43,400 & 19,000 \\
\hline - - & GSD-5 published ${ }^{2}$ & - - & - - & - - & - & - & -- & 81,300 & 38,200 & 41,000 & 17,400 \\
\hline - - & Percent recovery & -- & - - & - - & -- & - & -- & $105 \%$ & $108 \%$ & $106 \%$ & $109 \%$ \\
\hline-- & GSD-3 laboratory & - - & -- & - & -- & -- & -- & 68,400 & 1,460 & 48,100 & 21,100 \\
\hline - - & GSD-3 published ${ }^{2}$ & - & -- & - - & - & - & -- & 63,700 & 1,570 & 45,500 & 20,400 \\
\hline - - & Percent recovery & - - & - - & - - & - - & - - & - - & $107 \%$ & $93 \%$ & $106 \%$ & $103 \%$ \\
\hline
\end{tabular}

Footnotes at end of table. 
Appendix 5. Major and trace element concentrations in lake-bottom sediment samples from sites in Woods Inlet of Lake Worth, Fort Worth, Texas, 2006-Continued.

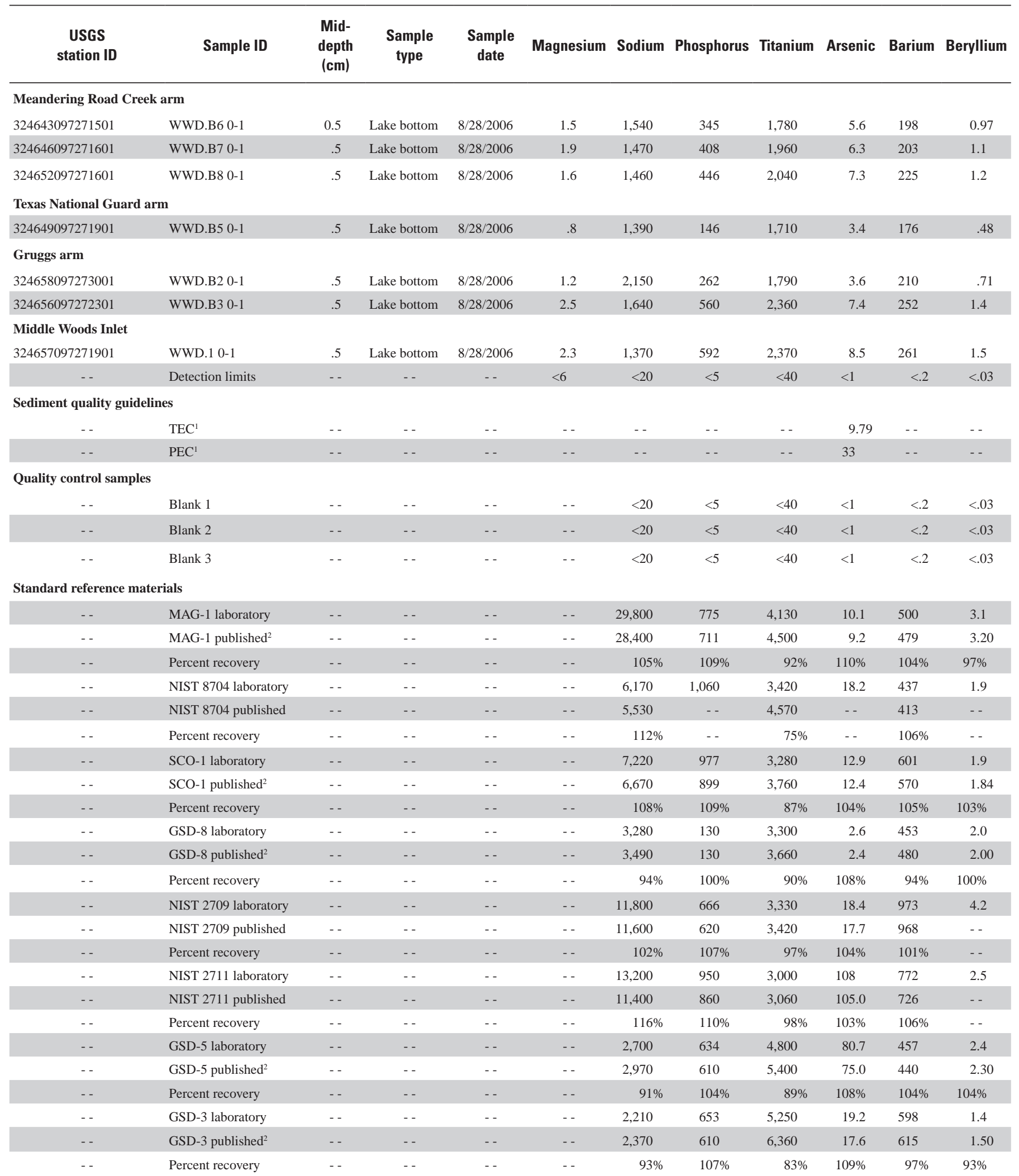

Footnotes at end of table. 
Appendix 5. Major and trace element concentrations in lake-bottom sediment samples from sites in Woods Inlet of Lake Worth, Fort Worth, Texas, 2006-Continued.

\begin{tabular}{|c|c|c|c|c|c|c|c|c|c|c|c|}
\hline $\begin{array}{c}\text { USGS } \\
\text { station ID }\end{array}$ & Sample ID & $\begin{array}{l}\text { Mid- } \\
\text { depth } \\
\text { (cm) }\end{array}$ & $\begin{array}{c}\text { Sample } \\
\text { type }\end{array}$ & $\begin{array}{c}\text { Sample } \\
\text { date }\end{array}$ & Cadmium & Cobalt & Chromium & Copper & Mercury & Lithium & Manganese \\
\hline \multicolumn{12}{|c|}{ M eandering $\mathrm{R}$ oad $\mathrm{C}$ reek arm } \\
\hline 324643097271501 & WWD.B6 0-1 & 0.5 & Lake bottom & $8 / 28 / 2006$ & 0.75 & 3.9 & 39.7 & 16.5 & 0.05 & 20.2 & 354 \\
\hline 324646097271601 & WWD.B7 0-1 & .5 & Lake bottom & $8 / 28 / 2006$ & 1.1 & 4.7 & 51.4 & 21.6 & .06 & 23.3 & 392 \\
\hline 324652097271601 & WWD.B8 0-1 & .5 & Lake bottom & $8 / 28 / 2006$ & .71 & 5.3 & 45.6 & 18.0 & .05 & 25.8 & 507 \\
\hline 324649097271901 & WWD.B5 0-1 & .5 & Lake bottom & $8 / 28 / 2006$ & .12 & 2.1 & 22.4 & 10.3 & .15 & 11.4 & 182 \\
\hline \multicolumn{12}{|l|}{ Gruggs arm } \\
\hline 324658097273001 & WWD.B2 0-1 & .5 & Lake bottom & $8 / 28 / 2006$ & .25 & 3.7 & 29.7 & 12.9 & .02 & 15.6 & 272 \\
\hline 324656097272301 & WWD.B3 0-1 & .5 & Lake bottom & $8 / 28 / 2006$ & .51 & 6.8 & 46.0 & 19.5 & .04 & 28.4 & 653 \\
\hline \multicolumn{12}{|l|}{ M iddle Woods Inlet } \\
\hline-- & $\mathrm{TEC}^{1}$ & - & -- & -- & .99 & -- & 43.4 & 31.6 & .18 & -- & - - \\
\hline -. & $\mathrm{PEC}^{1}$ & - - & - - & - - & 4.98 & - - & 111 & 149 & 1.06 & - - & - - \\
\hline \multicolumn{12}{|c|}{ Quality control samples } \\
\hline-- & Blank 1 & -- & - - & -- & $<.007$ & $<.03$ & $<.5$ & $<2$ & -- & .6 & $<.7$ \\
\hline- & Blank 2 & -- & - - & -- & $<.007$ & $<.03$ & $<.5$ & $<2$ & -- & .3 & $<.7$ \\
\hline -. & Blank 3 & -. & - - & - - & $<.007$ & $<.03$ & $<.5$ & $<2$ & - & 1.2 & $<.7$ \\
\hline \multicolumn{12}{|c|}{ Standard reference materials } \\
\hline - - & MAG-1 laboratory & - & -- & -- & .21 & 22.6 & 113 & 36.3 & -- & 77.9 & 776 \\
\hline -. & MAG-1 published ${ }^{2}$ & -. & - - & - - & .20 & 20.4 & 97 & 30.0 & -. & 79.0 & 760 \\
\hline- & Percent recovery & -- & - & -- & $104 \%$ & $111 \%$ & $116 \%$ & $121 \%$ & - & $99 \%$ & $102 \%$ \\
\hline-- & GSD-8 laboratory & -- & -- & -- & .02 & 3.4 & 5.0 & 5.1 & -- & 14.0 & 344 \\
\hline-- & GSD-8 published2 & -- & -- & -- & .08 & 3.6 & 7.60 & 4.1 & - - & 13.2 & 310 \\
\hline-- & Percent recovery & -- & -- & -- & $25 \%$ & $94 \%$ & $66 \%$ & $124 \%$ & -- & $106 \%$ & $111 \%$ \\
\hline- & NIST 2709 laboratory & -- & - & -- & .41 & 13.4 & 125 & 36.1 & -- & 53.6 & 555 \\
\hline-- & NIST 2709 published & -- & -- & -- & .38 & 13.4 & 130 & 34.6 & -- & -- & 538 \\
\hline - - & Percent recovery & -- & - - & -- & $108 \%$ & $100 \%$ & $96 \%$ & $104 \%$ & -- & - - & $103 \%$ \\
\hline-- & NIST 2711 laboratory & -- & -- & -- & 42.6 & 10.4 & 49.4 & 115 & -- & 29.7 & 708 \\
\hline- & NIST 2711 published & -- & - - & -- & 41.70 & 10.0 & 47 & 114.0 & -- & - - & 638 \\
\hline-- & Percent recovery & -- & -- & -- & $102 \%$ & $104 \%$ & $105 \%$ & $101 \%$ & -- & -- & $111 \%$ \\
\hline-- & GSD-5 laboratory & -- & -- & -- & .90 & 20.0 & 81.8 & 143 & -- & 46.6 & 1230 \\
\hline-- & GSD-5 published ${ }^{2}$ & -- & -- & -- & .82 & 18.9 & 70.00 & 137.0 & -- & 45.0 & 1160 \\
\hline-- & Percent recovery & - & - - & -- & $110 \%$ & $106 \%$ & $117 \%$ & $104 \%$ & -- & $104 \%$ & $106 \%$ \\
\hline-- & GSD-3 laboratory & -- & -- & -- & .25 & 11.6 & 82.9 & 189 & -- & 35.3 & 435 \\
\hline-- & GSD-3 published ${ }^{2}$ & -- & -- & -- & .10 & 11.7 & 87.00 & 177.0 & -- & 33.0 & 390 \\
\hline - - & Percent recovery & - - & - - & - - & $250 \%$ & $99 \%$ & $95 \%$ & $107 \%$ & - - & $107 \%$ & $112 \%$ \\
\hline
\end{tabular}

Footnotes at end of table. 
Appendix 5. Major and trace element concentrations in lake-bottom sediment samples from sites in Woods Inlet of Lake Worth, Fort Worth, Texas, 2006-Continued.

\begin{tabular}{|c|c|c|c|c|c|c|c|c|c|c|c|c|}
\hline $\begin{array}{c}\text { USGS } \\
\text { station ID }\end{array}$ & Sample ID & $\begin{array}{l}\text { Mid- } \\
\text { depth } \\
\text { (cm) }\end{array}$ & $\begin{array}{c}\text { Sample } \\
\text { type }\end{array}$ & $\begin{array}{c}\text { Sample } \\
\text { date }\end{array}$ & Nickel & Lead & Scandium & Strontium & Vanadium & Zinc & Gallium & Rubidium \\
\hline 324643097271501 & WWD.B6 0-1 & 0.5 & Lake bottom & $8 / 28 / 2006$ & 13.2 & 26.8 & 5.3 & 205 & 40.6 & 82.3 & 7.0 & 38.7 \\
\hline 324646097271601 & WWD.B7 0-1 & .5 & Lake bottom & $8 / 28 / 2006$ & 14.7 & 34.5 & 6.1 & 209 & 49.0 & 108 & 8.3 & 44.1 \\
\hline 324652097271601 & WWD.B8 0-1 & .5 & Lake bottom & $8 / 28 / 2006$ & 15.6 & 29.4 & 6.8 & 228 & 55.0 & 85.8 & 9.3 & 49.3 \\
\hline 324649097271901 & WWD.B5 0-1 & .5 & Lake bottom & $8 / 28 / 2006$ & 5.2 & 11.8 & 3.1 & 80.7 & 19.4 & 24.1 & 3.3 & 20.9 \\
\hline \multicolumn{13}{|l|}{ Gruggs arm } \\
\hline 324658097273001 & WWD.B2 0-1 & .5 & Lake bottom & $8 / 28 / 2006$ & 8.9 & 17.9 & 3.9 & 115 & 28.4 & 40.8 & 5.2 & 32.3 \\
\hline 324656097272301 & WWD.B3 0-1 & .5 & Lake bottom & $8 / 28 / 2006$ & 17.7 & 28.0 & 7.8 & 212 & 64.0 & 76.5 & 10.6 & 60.1 \\
\hline \multicolumn{13}{|l|}{ M iddle Woods Inlet } \\
\hline - - & $\mathrm{TEC}^{1}$ & - - & - - & - & 22.7 & 35.8 & - - & - - & - & 121 & - - & - \\
\hline -- & $\mathrm{PEC}^{1}$ & - - & -- & -- & 48.6 & 128 & -- & -- & -- & 459 & -- & -- \\
\hline \multicolumn{13}{|c|}{ Quality control samples } \\
\hline - - & Blank 1 & - - & - - & - - & $<.3$ & $<.4$ & $<.04$ & $<.8$ & $<.2$ & $<3$ & $<.02$ & $<.01$ \\
\hline-- & Blank 2 & - & - & -- & $<.3$ & $<.4$ & $<.04$ & $<.8$ & $<.2$ & $<3$ & $<.02$ & $<.01$ \\
\hline-- & Blank 3 & -- & -- & -- & $<.3$ & $<.4$ & $<.04$ & $<.8$ & $<.2$ & $<3$ & $<.02$ & $<.01$ \\
\hline \multicolumn{13}{|c|}{ Standard reference materials } \\
\hline-- & MAG-1 laboratory & - & - & - & 50.2 & 26.7 & 19.0 & 148 & 146 & 141 & 22.8 & 150 \\
\hline- & MAG-1 published ${ }^{2}$ & -- & -- & - & 53.0 & 24.0 & 17.2 & 146 & 140 & 130 & 20.4 & 149 \\
\hline-- & GSD-8 laboratory & -- & - & -- & 1.5 & 20.5 & 5.4 & 48.0 & 23.6 & 45.9 & 10.2 & 127 \\
\hline-- & GSD-8 published ${ }^{2}$ & -. & -. & -- & 2.7 & 21.0 & 5.7 & 52.0 & 26 & 43.0 & 10.8 & 132 \\
\hline - - & Percent recovery & -- & - & - & $56 \%$ & $98 \%$ & $95 \%$ & $92 \%$ & $91 \%$ & $107 \%$ & $94 \%$ & $96 \%$ \\
\hline-- & NIST 2709 laboratory & - & - - & - & 80.8 & 18.5 & 12.9 & 234 & 115 & 108 & 16.3 & 92.5 \\
\hline- & NIST 2709 published & - & -- & - & 88.0 & 18.9 & 12.0 & 231 & 112.0 & 106 & 14.0 & 96 \\
\hline-- & Percent recovery & -- & - & -- & $92 \%$ & $98 \%$ & $108 \%$ & $101 \%$ & $103 \%$ & $102 \%$ & $116 \%$ & $96 \%$ \\
\hline-- & NIST 2711 laboratory & -- & -- & -- & 20.1 & 1,220 & 10.6 & 258 & 89.5 & 363 & 16.6 & 120 \\
\hline-- & NIST 2711 published & - & -- & - & 20.6 & 1,162 & 9 & 245 & 82 & 350 & 15.0 & 110 \\
\hline - & Percent recovery & - & -- & - & $98 \%$ & $105 \%$ & $118 \%$ & $105 \%$ & $110 \%$ & $104 \%$ & $111 \%$ & $109 \%$ \\
\hline-- & GSD-5 laboratory & -. & - & - & 36.4 & 111 & 15.7 & 214 & 112 & 267 & 19.9 & 124 \\
\hline-- & GSD-5 published ${ }^{2}$ & -- & -- & -- & 34.0 & 112.0 & 14.5 & 204.0 & 109 & 243.0 & 20.3 & 118 \\
\hline-- & Percent recovery & - & -- & - & $107 \%$ & $99 \%$ & $108 \%$ & $105 \%$ & $103 \%$ & $110 \%$ & $98 \%$ & $105 \%$ \\
\hline - & GSD-3 laboratory & - & -- & - & 26.2 & 41.4 & 15.0 & 94.5 & 122 & 58.0 & 15.1 & 74.7 \\
\hline-- & GSD-3 published ${ }^{2}$ & - & - & - & 25.6 & 40.0 & 14.3 & 90.0 & 120 & 52.0 & 15.9 & 79 \\
\hline - - & Percent recovery & - - & - - & - & $102 \%$ & $104 \%$ & $105 \%$ & $105 \%$ & $102 \%$ & $112 \%$ & $95 \%$ & $95 \%$ \\
\hline
\end{tabular}

Footnotes at end of table. 
Appendix 5. Major and trace element concentrations in lake-bottom sediment samples from sites in Woods Inlet of Lake Worth, Fort Worth, Texas, 2006-Continued.

\begin{tabular}{|c|c|c|c|c|c|c|c|c|c|c|c|}
\hline $\begin{array}{c}\text { USGS } \\
\text { station ID }\end{array}$ & Sample ID & $\begin{array}{c}\text { Mid- } \\
\text { depth } \\
\text { (cm) }\end{array}$ & $\begin{array}{l}\text { Sample } \\
\text { type }\end{array}$ & $\begin{array}{l}\text { Sample } \\
\text { date }\end{array}$ & Yttrium & Niobium & $\begin{array}{l}\text { Molyb- } \\
\text { denum }\end{array}$ & Silver & Antimony & Cesium & Lanthanum \\
\hline 324643097271501 & WWD.B6 0-1 & 0.5 & Lake bottom & $8 / 28 / 2006$ & 16.3 & 4.2 & 0.95 & $<1$ & 0.57 & 2.3 & 24.2 \\
\hline 324646097271601 & WWD.B7 0-1 & .5 & Lake bottom & $8 / 28 / 2006$ & 17.0 & 4.4 & 1.2 & $<1$ & .69 & 2.7 & 24.1 \\
\hline 324652097271601 & WWD.B8 0-1 & .5 & Lake bottom & $8 / 28 / 2006$ & 17.7 & 8.2 & 1.0 & $<1$ & .61 & 3.1 & 25.5 \\
\hline \multicolumn{12}{|c|}{ Texas National G uard arm } \\
\hline 324649097271901 & WWD.B5 0-1 & .5 & Lake bottom & $8 / 28 / 2006$ & 16.2 & 3.2 & .40 & $<1$ & .30 & 1.1 & 19.2 \\
\hline \multicolumn{12}{|l|}{ Gruggs arm } \\
\hline 324658097273001 & WWD.B2 0-1 & .5 & Lake bottom & $8 / 28 / 2006$ & 15.2 & 4.1 & .41 & $<1$ & .34 & 1.7 & 24.6 \\
\hline 324656097272301 & WWD.B3 0-1 & .5 & Lake bottom & $8 / 28 / 2006$ & 19.5 & 7.2 & .80 & $<1$ & .62 & 3.6 & 28.9 \\
\hline \multicolumn{12}{|l|}{ M iddle Woods I nlet } \\
\hline -- & $\mathrm{TEC}^{1}$ & -. & -. & - - & -- & -- & -- & - - & -- & -- & - - \\
\hline -- & $\mathrm{PEC}^{1}$ & -- & -. & -- & -- & -- & -- & -- & -- & -- & -- \\
\hline \multicolumn{12}{|c|}{ Quality control samples } \\
\hline -- & Blank 1 & - - & -- & - - & $<.05$ & $<.1$ & $<.05$ & $<1$ & $<.04$ & $<.003$ & $<.05$ \\
\hline-- & Blank 2 & -- & - - & - - & $<.05$ & $<.1$ & $<.05$ & $<1$ & $<.04$ & $<.003$ & $<.05$ \\
\hline-- & Blank 3 & -- & -- & - - & $<.05$ & $<.1$ & $<.05$ & $<1$ & $<.04$ & $<.003$ & $<.05$ \\
\hline \multicolumn{12}{|c|}{ Standard reference materials } \\
\hline -- & MAG-1 laboratory & -- & -- & - - & 24.7 & 20 & 1.1 & $<1$ & .91 & 8.5 & 46.6 \\
\hline-- & MAG-1 published ${ }^{2}$ & -- & -- & -- & 28.0 & 12.0 & 1.60 & .08 & .96 & 8.60 & 43.0 \\
\hline -- & GSD-8 laboratory & -- & -- & -- & 15.0 & 37 & .50 & $<1$ & 0.32 & 3.2 & 28.2 \\
\hline-- & GSD-8 published ${ }^{2}$ & -- & -- & - - & 18.0 & 35.0 & .54 & -- & 0.24 & 3.60 & 30.0 \\
\hline - - & Percent recovery & -- & - - & - - & $83 \%$ & $106 \%$ & $93 \%$ & -. & $133 \%$ & $89 \%$ & $94 \%$ \\
\hline -- & NIST 2709 laboratory & -- & - - & -- & 17.4 & 12 & 2.0 & $<1$ & 6.3 & 5.4 & 22.5 \\
\hline-- & NIST 2709 published & -- & -- & -- & 18.0 & -- & 2 & -- & 7.90 & 5.30 & 23.0 \\
\hline-- & Percent recovery & -- & -- & -- & $97 \%$ & -- & $100 \%$ & -- & $80 \%$ & $102 \%$ & $98 \%$ \\
\hline-- & NIST 2711 laboratory & -- & -- & -- & 31.0 & 26 & 1.6 & 4.7 & 18.8 & 6.5 & 39.6 \\
\hline-- & NIST 2711 published & -- & -- & -- & 25.0 & -- & 1.60 & 4.63 & 19.40 & 6.10 & 40.0 \\
\hline-- & Percent recovery & -- & -- & -- & $124 \%$ & -- & $100 \%$ & $102 \%$ & $97 \%$ & $107 \%$ & $99 \%$ \\
\hline-- & GSD-5 laboratory & -- & -- & -- & 21.3 & 20 & 1.1 & $<1$ & 4.0 & 8.9 & 43.1 \\
\hline-- & GSD-5 published ${ }^{2}$ & -- & -- & -- & 26.0 & 19.0 & 1.20 & .36 & 3.90 & 9.40 & 46.0 \\
\hline-- & Percent recovery & -- & -- & -- & $82 \%$ & $105 \%$ & $92 \%$ & -- & $103 \%$ & $95 \%$ & $94 \%$ \\
\hline-- & GSD-3 laboratory & -- & -- & -- & 17.0 & 14 & 92.9 & $<1$ & 6.5 & 7.2 & 37.2 \\
\hline -- & GSD-3 published ${ }^{2}$ & -- & -. & -. & 22.0 & 16.0 & 92.00 & .59 & 5.40 & 7.80 & 39.0 \\
\hline -- & Percent recovery & -- & -. & -. & $77 \%$ & $88 \%$ & $101 \%$ & -. & $120 \%$ & $92 \%$ & $95 \%$ \\
\hline
\end{tabular}

Footnotes at end of table. 
Appendix 5. Major and trace element concentrations in lake-bottom sediment samples from sites in Woods Inlet of Lake Worth, Fort Worth, Texas, 2006-Continued.

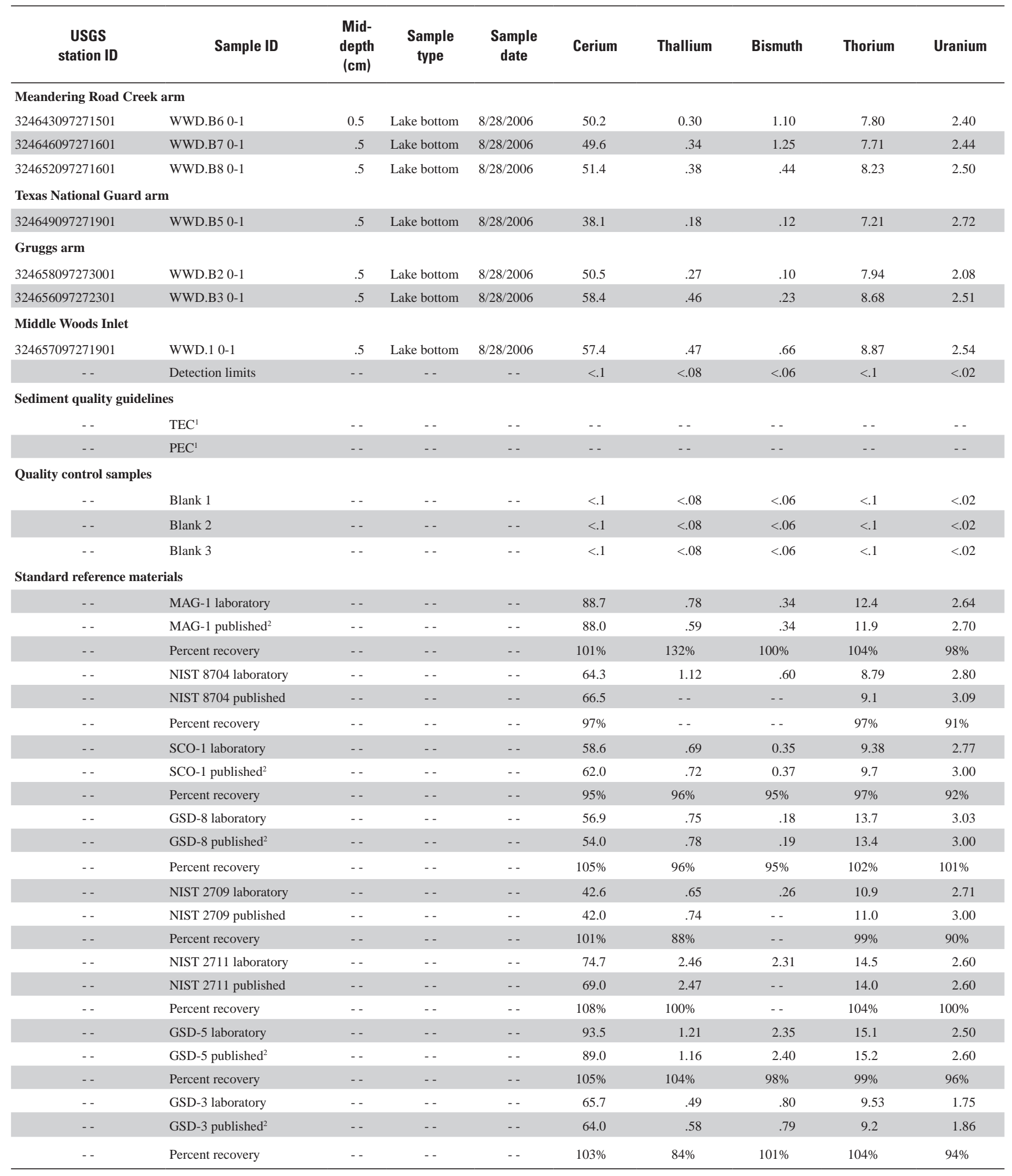

${ }^{1}$ TEC, Threshold effects concentration; PEC, Probable effects concentration (MacDonald and others, 2000).

${ }^{2}$ Potts and others, 1992. 
Publishing support provided by

Lafayette Publishing Service Center

Information regarding water resources in Texas is available at http://tx.usgs.gov/ 